\title{
Generating Culture
}

\author{
a Matter of Potential
}

by

Jeremy Van Dyke

Supervisor

Dr. Stephen Fai

A thesis submitted to the Faculty of Graduate and Postdoctoral Affairs in partial fulfillment of the requirements for the degree of:

\section{Master of Architecture}

Azreili School of Architecture and Urbanism

Carleton University

Ottawa, Ontario

April 12, 2011

(c) 2011

Jeremy Van Dyke 
Library and Archives Canada

Published Heritage Branch

395 Wellington Street Ottawa ON K1A ON4 Canada
Bibliotheque et

Archives Canada

Direction du

Patrimoine de l'édition

395 , rue Wellington Ottawa ON K1A 0N4

Canada
Your file Votre référence

ISBN: 978-0-494-81626-4

Our file Notre référence

ISBN: 978-0-494-81626-4
NOTICE:

The author has granted a nonexclusive license allowing Library and Archives Canada to reproduce, publish, archive, preserve, conserve, communicate to the public by telecommunication or on the Internet, loan, distribute and sell theses worldwide, for commercial or noncommercial purposes, in microform, paper, electronic and/or any other formats.

The author retains copyright ownership and moral rights in this thesis. Neither the thesis nor substantial extracts from it may be printed or otherwise reproduced without the author's permission.
AVIS:

L'auteur a accordé une licence non exclusive permettant à la Bibliothèque et Archives Canada de reproduire, publier, archiver, sauvegarder, conserver, transmettre au public par télécommunication ou par l'Internet, prêter, distribuer et vendre des thèses partout dans le monde, à des fins commerciales ou autres, sur support microforme, papier, électronique et/ou autres formats.

L'auteur conserve la propriété du droit d'auteur et des droits moraux qui protège cette thèse. $\mathrm{Ni}$ la thèse ni des extraits substantiels de celle-ci ne doivent être imprimés ou autrement reproduits sans son autorisation.
In compliance with the Canadian Privacy Act some supporting forms may have been removed from this thesis.

While these forms may be included in the document page count, their removal does not represent any loss of content from the thesis.
Conformément à la loi canadienne sur la protection de la vie privée, quelques formulaires secondaires ont èté enlevés de cette thèse.

Bien que ces formulaires aient inclus dans la pagination, il n'y aura aucun contenu manquant. 


\begin{abstract}
This thesis challenges prevailing attitudes towards the notions of heritage and authenticity in regards to both the built environment and our respective "cultures", with this challenge made manifest through an architectural intervention acted upon a derelict church within Ottawa's downtown core. Utilizing Giorgio Agamben's writings On Potentiality as a critical lens through which to focus, the moral implications of elevating built forms and other cultural systems to the level of emblematic symbols, or "signifiers", will be debated. In treating a religious building with inherent ethno-cultural connotations as a utilitarian object that adapts to accommodate societal needs, the proposed architecture creates a forum within which the idea of cultural identity as a liminal construct, with a greater potential in its indefinite state, may be explored. By utilizing notions of engagement, exchange, and dialogue, this project seeks to emancipate the potential of two entities within Ottawa that are too often stifled by prevailing beliefs of absolute, and unified cultural identities: the built fabric, and the refugee community that dwells within it. By providing an infrastructure that catalyzes the generation and dissemination of group identity - the Culture Generator - this project quietly hopes that deleterious manifestations of ethno-cultural identity may be avoided, and that cultural dialogue may approach a condition of constructive exchange, rather than integration or assimilation. In so doing, it may spur those who may interact with, or utilize the Culture Generator to ask, "Where does authenticity lie?"
\end{abstract}




\section{Table of Contents}

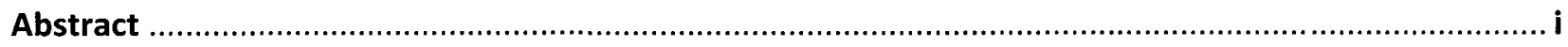

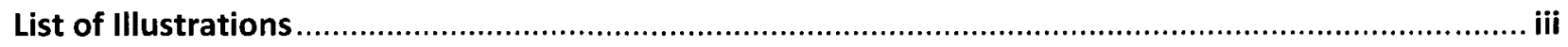

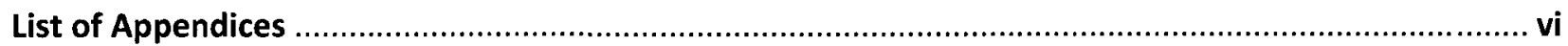

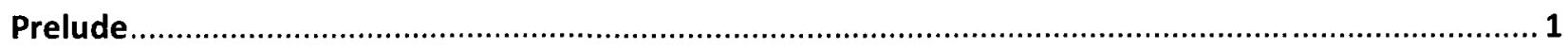

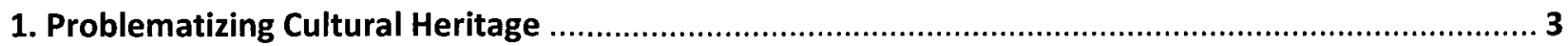

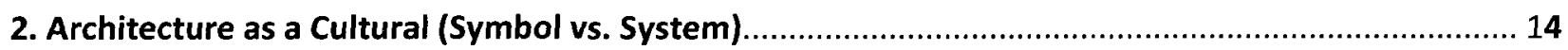

3. Heritage Case Study: Ottawa's Portuguese Community Centre as a Cultural Symbol, or System? .... 20

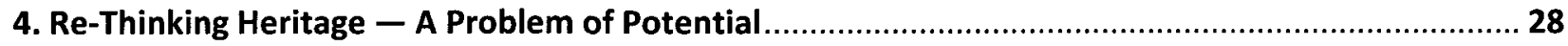

5. Generating Culture: Enabling Ottawa's Refugee Population ......................................................... 32

5.1 Indeterminate Shelter Catalyst - Diversified Neighborhood Infrastructure ................................ 41

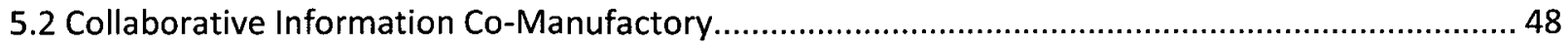

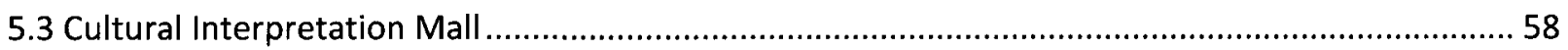

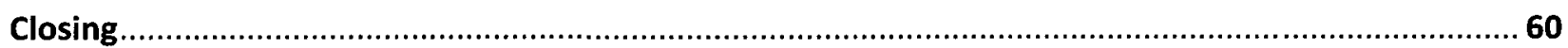

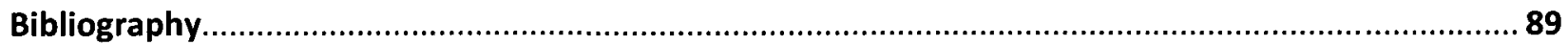




\section{List Of Illustrations}

\section{Title/Description}

\section{Page Number}

1 Vellinga, Marcel, Paul Oliver, and Alexander Bridge. Geographical Divisions of Vernacular Building Typologies, 2007. Map. Print. Vellinga, Marcel, Paul Oliver, and Alexander Bridge. Atlas of Vernacular Architecture of the World. Abingdon, Oxon: Routledge, 2007.

2 Stadt Essen. Germany, Essen, Passers-by Watching the Burning Synagogue in Steeler street, Nov 10, 1938. Photograph. Yad Vashem Photo Archives, Israel. Web : http://collections.yadvashem.org/photosarchive/en-us/4419365.html

3 Yad Vashem. Wiesbaden, Germany, The Michelsberg Synagogue Burning. Nov 10, 1938. Photograph. Yad Vashem, Israel . Web : nttp://collections.yadvashem.org/photosarchive/en-us/59446.htmi

4 German Federal Archive. Ruins of the Neumarkt and the Frauenkirche after Allied bombing, Dresden, German., circa 15 Feb 1945. Photograph. German Federal Archives, Germany. Web:

http://ww2db.com/image.php?image_id $=9638$

5 Al-Rumaye, Ahmad. U.S. Soldiers Inspect the Scene of a Double Bombing, Bayah, Baghdad. Feb 11, 2009. Photograph. Getty Images. Web:

http://www.foreignpolicy.com/articles/2010/08/30/inheriting_iraq?page=full

6 Ramsey. Parade der Wermacht am Zeppelinfield warend des Reichsparteitages. circa 1938. Nuremburg. Web: http://www.germanarchitecture.info/GERMANY/TEN/TEN-NS-02.htm

7 Israeli Project. Model of the Yeshiva of Porat Yosef, the Jewish Quarter, overlooking the Wailing Wall (Architect Moshe Safdie), 1970. Photograph. Archive of the Israeli Project, Israel. Print: Weizman, Eyal. Hollow Land. New York, Verso, 2007. 45. 
8 Israeli Project. Housing Cluster in Gilo, 1972 (Architect Salo Hershman, 1970.

Photograph. Israeli Project, Israel. Print: Weizman, Eyal. Hollow Land. New York, Verso, 2007. 45.

9 Shimoda, J. St. Brigid's Centre for the Arts and Humanities. March 5, 2010.

Photograph. Shimoda, J. Canada. Web:

http://www.flickr.com/photos/jeffshimoda/4421812964/

10 Author. Portuguese Community Centre, 115 Echo Drive, Ottawa, Ontario. (Facing East). October 29, 2010. Photograph.

11 Author. Portuguese Community Centre, 115 Echo Drive, Ottawa, Ontario.

(Facing South). October 29, 2010. Photograph.

12 Author. Portuguese Community Centre, 115 Echo Drive, Ottawa, Ontario. (Facing West). October 29, 2010. Photograph.

13 Author. Detail : Portuguese Community Centre, 115 Echo Drive, Ottawa,

Ontario. October 29, 2010. Photograph.

14 Author. Detail : Portuguese Community Centre, 115 Echo Drive, Ottawa,

Ontario. October 29, 2010. Photograph.

15 Author. Detail : Portuguese Community Centre, 115 Echo Drive, Ottawa, Ontario. October 29, 2010. Photograph.

16 Author. Detail : Portuguese Community Centre, 115 Echo Drive, Ottawa, Ontario. October 29, 2010. Photograph.

17 Author. Portuguese Community Centre and its Environs. November, 2010. Digital Media.

18 Rene, Pierre Allain. Portuguese youths bringing loaves of bread to Pentecost Feast. June 4, 1979. Photograph. Ottawa Journal, Ottawa, Canada. Ottawa Archives.

19 Andrews, Newton. Ukrainian Church welcoming Bishop from Rochester, New York. Nov 21, 1954. Photograph. Newton, Andrews. Ottawa, Canada.

Ottawa Archives

20 Author. Distribution and growth of congregations - 115 Echo Drive. Nov 2010. Digital Media 
21 Author, Caravanserai in Akko, Israel.2007. Photograph.

22 Gholizadeh, Babak. Floor Plan of Karaj, Safavid Caravanserai. 2004. CAD

Drawing. Babak Gholizadeh, Iran. Web:

http://en.wikipedia.org/wiki/File:Carvansara_plan.gif

23 Levitt-Goodman Architects. Strachan House - Street (Architect Levitt-Goodman

Architects). 1997. Photograph. Levitt-Goodman Architects, Toronto. Web :

http://levittgoodmanarchitects.com/project? $p=$ strachan \&c1=residential\&c2=No

ne

24 Levitt-Goodman Architects. Strachan House - Kitchen (Architec:t Levitt-

Goodman). 1997. Photograph. Levitt-Goodman Architects, Toronto. Web :

http://levittgoodmanarchitects.com/project?p=strachan\& $c 1=$ residential $\& \mathrm{c} 2=\mathrm{No}$ ne

25 Levitt-Goodman Architects. Strachan House - Town Hall (Architect: LevittGoodman). 1997. Photograph. Levitt-Goodman Architects, Toronto. Web : http://levittgoodmanarchitects.com/project?p=strachan \&c1=residential\&c2=No ne

26 Levitt-Goodman Architects. Strachan House - Detail (Architect Levitt-Goodman). 1997. Photograph. Levitt-Goodman Architects, Toronto. Web : http://levittgoodmanarchitects.com/project? $p=$ strachan\& $1=$ residential $\& c 2=$ No ne

27 Price, Cedric. Plan for Potteries Thinkbelt, Staffordshire England (Architect Cedric Price), 1965.Drawing. Web: http://designmuseum.org/design/cedricprice

28 Price, Cedric. Drawing for Potteries Thinkbelt, Staffordshire England (Architect Cedric Price), 1965.Drawing. Web: http://designmuseum.org/design/cedricprice

29 Price, Cedric. Perspective Drawing for Potteries Thinkbelt, Staffordshire England (Architect Cedric Price), 1965.Drawing. Web: http://www.cityofsound.com/blog/2006/02/design_thinkbel.html 


\section{List of Appendices}

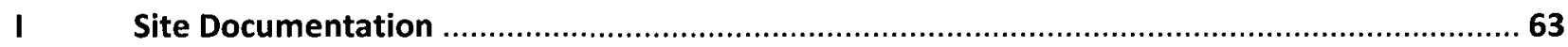

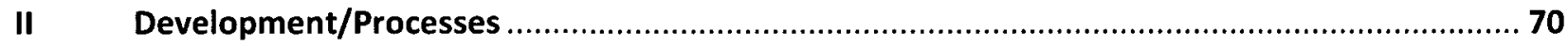

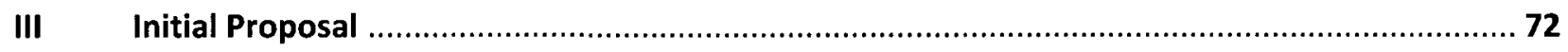

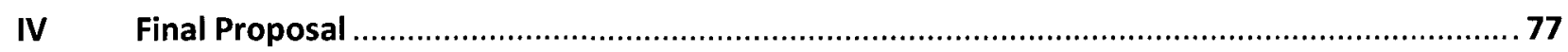




\section{Prelude}

T.S. Eliot once wrote in his literary and theological criticism After Strange Gods, that "tradition by itself is not enough"1, a proclamation that reflects the contemporary discourse on culture, identity, and the perceived authenticity of both. Eliot asserts that culture-specific systems such as literature and religion are privy to criticisms and revisions through time, in order to question their relevance and utility in an ever-changing society. If this assertion is taken as true, should other cultural systems such as art and architecture not be as well?

Architecture has been commonly seen as a tool to express, assert and delineate definitive spatial constructs specific to authentic cultural identities. In this view, architecture is a signifier that makes possible the understanding of something as "13th Century French", "High Renaissance Florentine", or "Typical French-Canadian", and is thereby indicative of the values, ethics and rituals of that identity. This view however, frames and fixes that identity, and thereby assumes an absolute understanding of particular cultural values, ethics, beliefs and practices through all time. This produces the illusion of a cohesive authentic architectural "tradition" that has been left to us.

This view of an absolute and essential cultural identity has been rightly challenged by the spatial reorganizations brought by globalization. The increase in mass migrations, displacements, and global trade of both goods and customs that we now call globalization has questioned the prior perception of spatial delineations of culture, as well as the understanding of its bounded and static nature through time. Through this reasoning, the architecture that is to some a signifier, is rather a projected fantasy - a patch used fix complete the cultural identity that is in fact always in flux.

\footnotetext{
${ }^{1}$ Eliot, T.S. After Strange Gods. 62
} 
I propose that architecture as signifier, as divine proof of heritage and tradition, is in fact detrimental to the growth and identity of a culture. By monumentalizing architecture and presenting it as archtypically emblematic of a culture, architecture traps that cultural identity in a backwards reflection, a folklore comparison that defines itself by excluding forms that do not belong to assigned archetypes. To better serve identity and authenticity, architecture should instead be seen as a cultural system, ideationally linked to the culture in which it is found, and not mechanically. In this way, architecture is then subject to the revisions that Eliot spoke of, allowing it to be as changeable or optional as that culture necessitates through time. In so doing, architecture evades the categorizations so often placed upon it, enabling its users to place inside, or embody within it what is pertinent in the shared experiences of that culture at any moment in time. This allows for new forms, new programs, and new hybrid identities all catalyzed by an architecture that best maintains the integrity of the processes that give form to the substance and fabric, and not the form itself. There is only authenticity in change. 


\section{Problematizing Cultural Heritage}

Many of us think of ourselves and our traditions and rituals as continuations of our timeless heritage immutable qualities that were brought to new lands by our ancestors, and passed down to us through time. In his work The Myth of Cultural Heritage, anthropologist Peter Niedermuller implies that these traditions are often understood in anthropological and ethnographic studies as "self-contained, bounded and unified constructs" ${ }^{2}$ or "discrete phenomena occupying discrete spaces", with these discrete spaces usually being the nation state - the geographical that we use most often to measure and delineate our cultural identities. Conversely, the notion that there is a de facto link between culture and a territorial boundary has informed the psychological basis that enables the formation of nation-states and their projected identities.

To support these projected identities, cultural groups have been determined by ensuring that a group under examination possessed a shared tradition, common cultural practices, and more concretely, a clearly defined territory. The study of both anthropology and ethnology were essentially bound to these notions of cultural differences organized and separated spatially, with cultural groups defined as bounded and unified homogenous cultural entities within a sea of other such homogenous groups. ${ }^{4}$ In this view, genetic lineage, exotic traditions, and cultural heritage (where heritage is seen as the timeless passing of practices and rituals from generation to generation in a continuous dogmatic fashion) are thought to be analogous with identity ${ }^{5}$, with these identities residing within static borders through time. This traditional view of identity and belonging, especially those notions of "authenticity" are

\footnotetext{
${ }^{2}$ Caglar, Hyphenated Identities and the Limits of Culture 169

${ }^{3}$ Gupta, Akh11, and Ferguson, James. Culture, Power, Place Critical Explorations in Anthropology 3

${ }^{4}$ Niedermuller, Ethnicty, Nationality, and the Myth of Cultural Heritage A European View 252

${ }^{5}$ Niedermuller, Ethntcity, Nationality, and the Myth of Cultural Herttage A European View 245
} 
then heavily reliant, if not uncompromisingly tied to locality, and therefore a static perception of cultural practices.

This dependence on locality is still prevalent within many fields of study, including that of the built environment. To better illustrate this point, we can examine a map from the Encyclopedia of Vernacular Architecture, a compendium that was assembled to catalogue the rich variation of vernacular solutions in built form the world over. This one image exemplifies the tendency to clearly categorize ethnocultures, using geographic location as the primary criteria to sort, order and classify them. This map insinuates graphically that specific ethno-cultural groups inhabit the space between each of the lines on the map, and that each of those groups has their own separate practices and traditions (in this case, specific to built forms ) exclusive from all other groups that do not fall within that line. The map, which comes as a result of decades of field research from contributors from many fields, is a direct manifestation of the belief of static cultural traditions continuing uninterrupted within distinct boundaries.

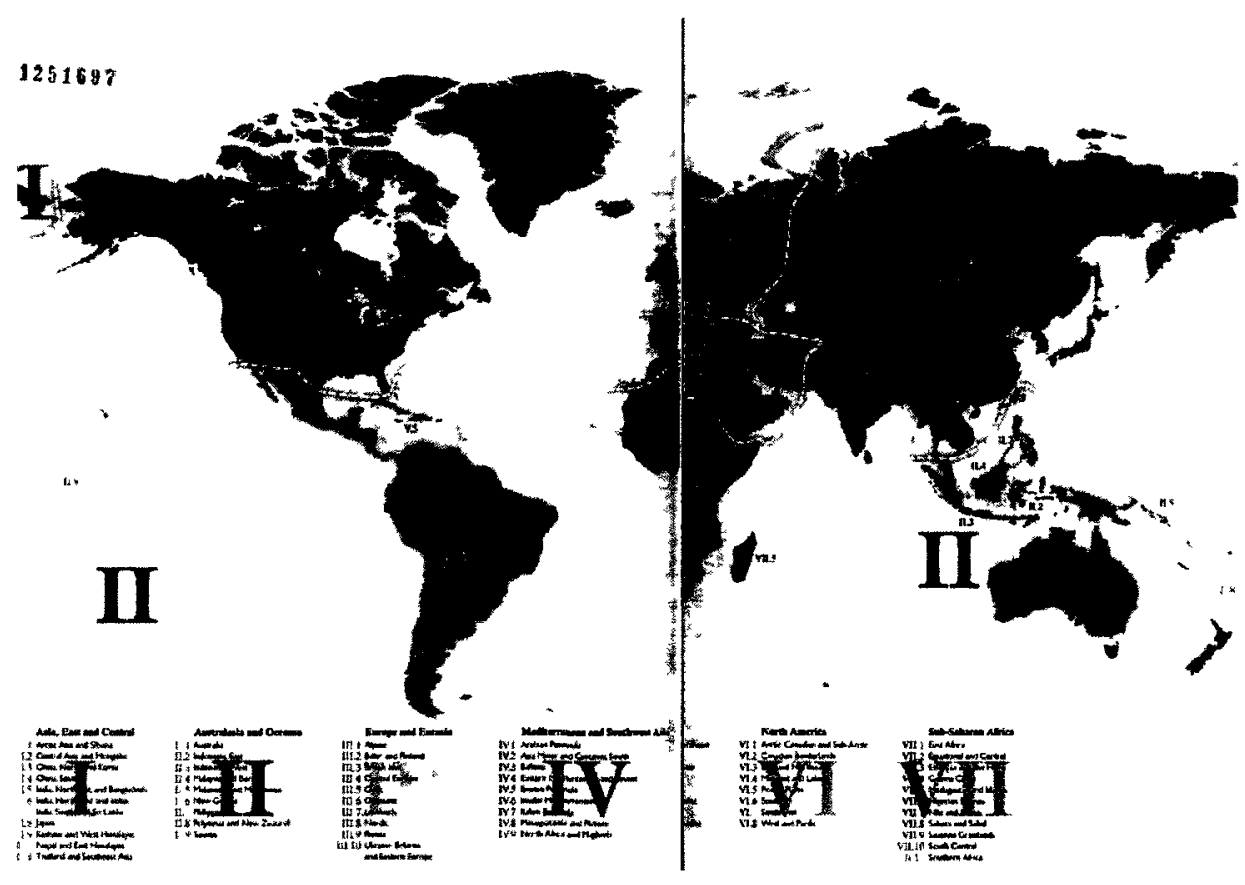

Fig. 1:

Map insinuating geographically bounded cultural groups through an analysis of the built environment. 
Unfortunately, this map is a dangerous over-simplification of how and why ethno-cultural identities are utilized the world over. This predominant view of historically and geographically determined ethno-cultural identity has rightly been questioned by globalization, the effects of which have served to blur the lines of the primary tools of cultural categorization.

Before these challenges to static and bounded cultural identities can be examined, "Globalization" must first be brought in to greater focus, and better understood in this context. According to Jan Nederveen Pieterse, Globalization "is a form of time-space compression.. ...It means more intensive interaction across wider space and in shorter time than before, in other words the experience of a shrinking world". ${ }^{6}$ Although there still exists a great deal of controversy surrounding the implications and extents of Globalization, in his book Globalization and Culture : Global Mélange, Pieterse attempts to collect and synthesize points of consensus from across fields to better develop his definition. The first point of agreement is that Globalization is largely being shaped by technological change. The boom in information and communication technologies has allowed for an infrastructure of global finance, capital mobility, trans-national communication, migration, travel and societal interactions ${ }^{7}$. The second is that this increase in capital mobility and population migration is uneven, and in favor of developed countries with established capitalist economies. The last, and most important to this discussion on cultural heritage, is that Globalization involves the reconfiguring of states and geographic territory. The increasing porosity of national boundaries that has allowed for increased flow of capital and labor forces has caused a correlated retreat and erosion of the nation state, while giving rise to ultra national regional states such as the European Union. The rapid subversion of the nation state by regional customs unions, free market unions, security alliances and regional states have all

\footnotetext{
${ }^{6}$ Pieterse, Nederveen Globahzation and Culture Global Melange 8

${ }^{7}$ Ibid 9
} 
challenged the preeminence of the nation state as a "container" to house disparate cultural traditions, and their timeless practices. ${ }^{8}$ If the boundary was necessary for so long to define an ethno-culture by excluding others, what becomes of an cultural group when that physical boundary becomes distorted or unreadable altogether? If just one of the three criteria (group, tradition, place) proves to be problematic, the predominant method of Defining cultural traditions becomes destabilized. What then does it mean to belong to an authentic cultural tradition?

As Eliot says, the problem with the word tradition is..."that it is so commonly applied: mis-applied, for the word itself implies a movement. Tradition cannot mean standing still."9 Although Eliot's observation was made nearly a century ago - and therefore outside the realm of contemporary debates on globalization and culture -it has proven to be insightful. Some, such as Pieterse now assert that these shortcomings in our understanding of tradition in the new global framework have existed through all recorded civilization, by recognizing globalization as a deep, historical process. ${ }^{10}$

Pieterse's position - that globalization has always existed, if under different names or guises - is based primarily on the findings of past historians. For example, in his book Cross-Cultural Trade in World History, Philip Curtin establishes the nature and existence of "trade diasporas". ${ }^{11}$ Curtin assigned this term to merchant groups that would spend decades, or even generations within a host culture to serve as permanent liaisons between traders of that culture, and their own. It is important to note in Curtin's' research that each of these merchant populations inevitably became obsolete. Being so effective in their role as catalysts of cultural exchange, the two seemingly disparate cultures would

\footnotetext{
${ }^{8}$ Pieterse, Jan Nederveen. Globalization and Culture Global Melange. 12

${ }^{9}$ Eliot, T.S. After Strange Gods 25

${ }^{10}$ Pieterse, Jan Nederveen. Globalization and Culture Global Melange 24

${ }^{11}$ Curtin, Philip. Cross Cultural Trade in World History 3
} 
either become so familiar with one another as to no longer require their mediating services, or the trade population would appropriate so many of the host culture's systems as to be nearly identical. ${ }^{12}$

A highly contrasting, but equally valid work is William McNeill's The Pursunt of Power, which details how various arms races since the turn of the 1st millennia $A D$ have transformed cultures across geographical and physical boundaries. ${ }^{13}$ By examining the implementation of warfare as an inherent cultural system within societies, McNeill does not simply discuss the transfer of ever-advancing weapons technologies, but also societal organizations, modes of production, and government typologies that evolved in relation to, or as a result of military advances. The outright fabrication of tradition is also mentioned, as power structures appropriated dress, uniforms, and academies to outdo one another on the battlefield. The Pursuit of Power illustrates that many cultural systems did not develop independently within confined spaces. Instead they were found to be the result of a process of combination or cross-contamination among ever-shifting and competing entities, and therefore cannot be said to be geographically bounded. ${ }^{14}$ In addition to this combinatory view of the cultural systems of war, it is also shown that traditions attributed to a given power structure can be manufactured in an ahistorical fashion if necessary. ${ }^{15}$ Taking such points into consideration, it is clear that a geographical challenge to the perception of cultural authenticity has always existed The notion of geographically bound nation states and ethnic territories functioning as a well-spring of culture is actually a recurring myth.

If exchanges of language, goods, practices, and even traditions have always existed, then the current phenomenon we call globalization has merely intensified and expanded it. The rate and totality of

\footnotetext{
${ }^{12}$ Curtin, Philp Cross Cultural Trade in World History 230

${ }^{13}$ Mcneill, William The Pursunt of Porwer 118

${ }^{14}$ Ibid 123

${ }^{15}$ Ibıd 131
} 
exchange in today's world has served simply to push an omnipresent condition - flux - to the foreground where we are forced to confront and consider its implications. This condition of flux that has now come to define our epoch - instantaneous communication, rapid transit, heavily interconnected economies, and constant and massive migrations all foster what Niedermuller calls a period of general transition, or liminality. ${ }^{16}$ Liminality in this circumstance can be defined as an ambiguous threshold where subjects belong neither to the society they once considered themselves to belong to, but are not yet a part of the society to which they have arrived. ${ }^{17}$ It is marked by disjunction, juxtaposition, and simultaneity, the quality of seeming to belong to several places at one time. In this liminal space, culture has been powerfully de-territorialized as it can no longer be clearly bounded in a concrete geographical sense. Displaced from the geographic boundaries, homogenous communities, and the environmental conditions that many use to falsely categorize it, the true nature of culture has been re-revealed in the globalized world as a working set of systems that are changeable, optional, adaptable and utilitarian in response to complex interrelationships in a deeply connected world. ${ }^{18}$ Instead of culture being commonly considered as a monolithic force resistant to change, culture can be understood as a relativistic and multidimensional concept that evolves over time. ${ }^{19}$ Rather than being regarded as historically and geographically determined and neatly categorized, culture is a combination of systems constructed in an ambivalent space of translation and negotiation. ${ }^{20}$ As such, culture is subject to the continuous re-evaluations of which Eliot spoke, and is defined not by harmful categorical exclusions, but by the ongoing dialogue and negotiation between entities.

\footnotetext{
${ }^{16}$ Niedermuller, Ethnicity, Nationality, and the Myth of Cultural Heritage A European View 245

${ }^{17}$ Victor Turner, The Ritual Process Structure and Ant1-Structure 95

${ }^{18}$ Geertz, Art as a Cultural System 1498

${ }^{19}$ Lawrence, Roderick J House Form and Culture What Have we Learnt in 30 Years ${ }^{2} 68$

${ }^{20}$ Baydar, Gulsum The Cultural Burden of Architecture 3
} 
This idea of a relative, negotiable culture complicates the perception of static ethno-cultural identities. Examining this problem allows us to ask the question "If cultural systems are boundless, highly relativistic and changeable, must the ethno-cultural identities that establish themselves based on relations with said cultural systems be as well?". Rather than being an identity composed of undying traditions, ethno-cultural identity itself is then perhaps in a liminal state, constantly shifting to respond to changing material conditions, semiotic codes, power relations, and relations among groups. ${ }^{21}$ Constantly fluctuating cultural systems (art, built forms, rituals) are still intrinsically linked to these identities, but they themselves offer no stable reference point to which a static identity can be established. The result, rather than timeless ethno-cultural heritage, is hybrid ethnic identities instead - a mélange of practices old and new, adapting continuously in relation to ever shifting societal conditions. Ethno-cultural identities seem to be defined not by the exclusive differences between them, but by the fact that the ongoing utilization and combination of cultural systems make such differentiations and exclusions impossible. They are defined by an irreducible lack - no identity is ever complete.

This assertion is problematic for power structures that have historically found the idea of complete and distinct ethno-cultural identities politically useful - such as the nation state and organized religious bodies. The idea of individuals belonging to a group that shares a culture and a unified history has been a powerful tool for conquest, oppression, division, and colonization. This ability to define cultural parameters, so that "others" can be created with which to compete economically and militarily, has long been exploited by power structures for self-serving aims, namely to drain off social tensions and internal conflicts by displacing them on to external "enemies". ${ }^{22}$ Asserting power and

\footnotetext{
${ }^{21}$ Smith, 1992, 512 - Problem with this citation - Smith is quoted in Niedermuller, have no references from Niedermuller'II

${ }^{22}$ Niedermuller, Ethnicty, Nationahty, and the Myth of Cultural Heritage A European View 253
} 
unifying disparate populations is made possible by assembling cultural elements, such as dress, language, literature, and elevating them to symbols of a Culture - as celebrated archetypes. The "other" is then established by excluding all symbols that do not fall within the established canon of archetypes. The self then, is not defined by its own intrinsic properties but by its relationship to the "other". ${ }^{23}$

Similarly, marginalized or disadvantaged ethno-cultural groups can employ the same devices to opposite effect. This tendency can be seen in nearly any cosmopolitan center that contains the liminal cultural groups that Pieterse speaks of, such as migrant workers, or large immigrant populations. Ethno-cultural groups recognize that they need an "expressive" and "visible" culture in order for it to be presented, so symbolic displays are composed of cultural systems salvaged from the past, such as folk dress and dances, and the marketed as ethno-cultural tradition. Such presentations offer public and social space without discrimination to marginalized groups, but more importantly, such public displays of ethno-cultural identity can then be used as a political tool to subvert established power structures by securing social position and empowerment. ${ }^{24}$

Less constructively, symbolic displays of ethno-cultural identity can become literal, and not figurative battlegrounds in divided societies. In his book, the Destruction of Memory, Robert Bevan describes how cultural systems, when elevated to a symbolic status within a society, become a primary target in ethno-cultural strife. Citing examples such as the erasure of Jewish property in Nazi Germany, the Allied bombings of Dresden and Cologne in the Second World War, and the deliberate attacks by Israeli forces on Palestinian institutions of culture, he elucidates how cultural symbols have been eradicated in an effort to destroy the perceived cultural content stored within them, thereby

\footnotetext{
${ }^{23}$ Bevan, Robert. The Destruction of Memory 134

${ }^{24}$ Niedermuller, Etbnictty, Nationalty, and the Myth of Cultural Heritage A European View 248
} 
eliminating the heritage and legitimacy of that identity. ${ }^{25}$ Even less permanent symbolic displays such as parades and pilgrimages fall victim to indiscriminate bombings, attesting to this tendency to destroy what is seen as a source of identity for an opposing ethno-cultural group. ${ }^{2627}$

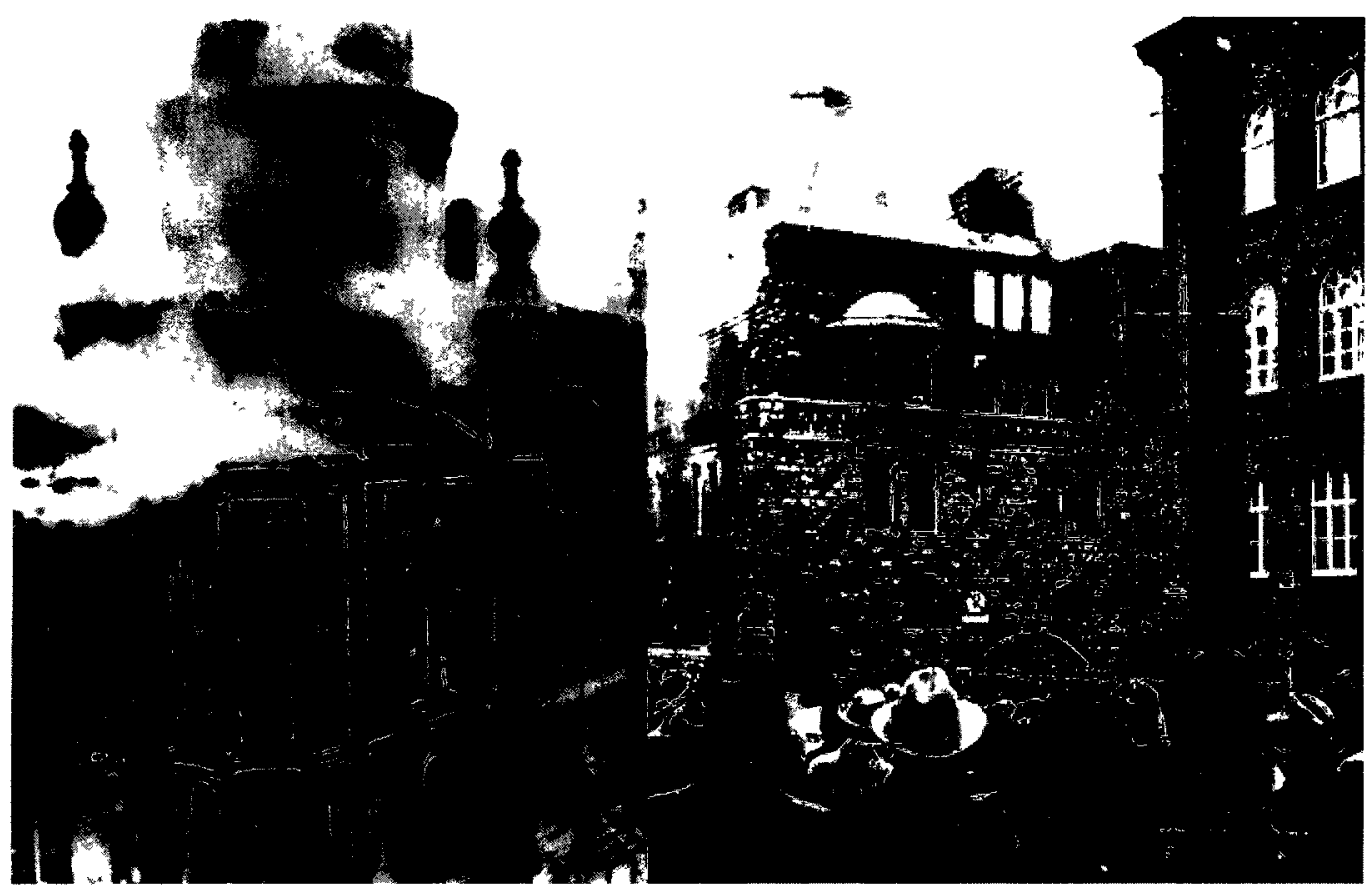

Fig. 2: Michelsberg Synagogue, set alight on Nov 9, 1938
Fig. 3: Synagogue in Essen, set alight on Nov 9, 1938

\footnotetext{
${ }^{25}$ Bevan, Robert. The Destruction of Memory. 8

${ }^{26}$ Reuters Africa. Timeline: Deadliest Attacks in Iraq Last Year. Reuters News Service: March 30, 2011 http://af.reuters.com/article/egyptNews/idAFLDE72T00420110330

${ }^{27}$ Morris, Loveday. Bomb Attacks in Iraq and Pakistan Target Sbiite Ptlgrims. The National (Online): Feb 06, 2010. http:/www.thenational.ae/news/worldwide/asia-pacific/bomb-attacks-in-iraq-and-pakistan-target-shiite-pilgrims
} 


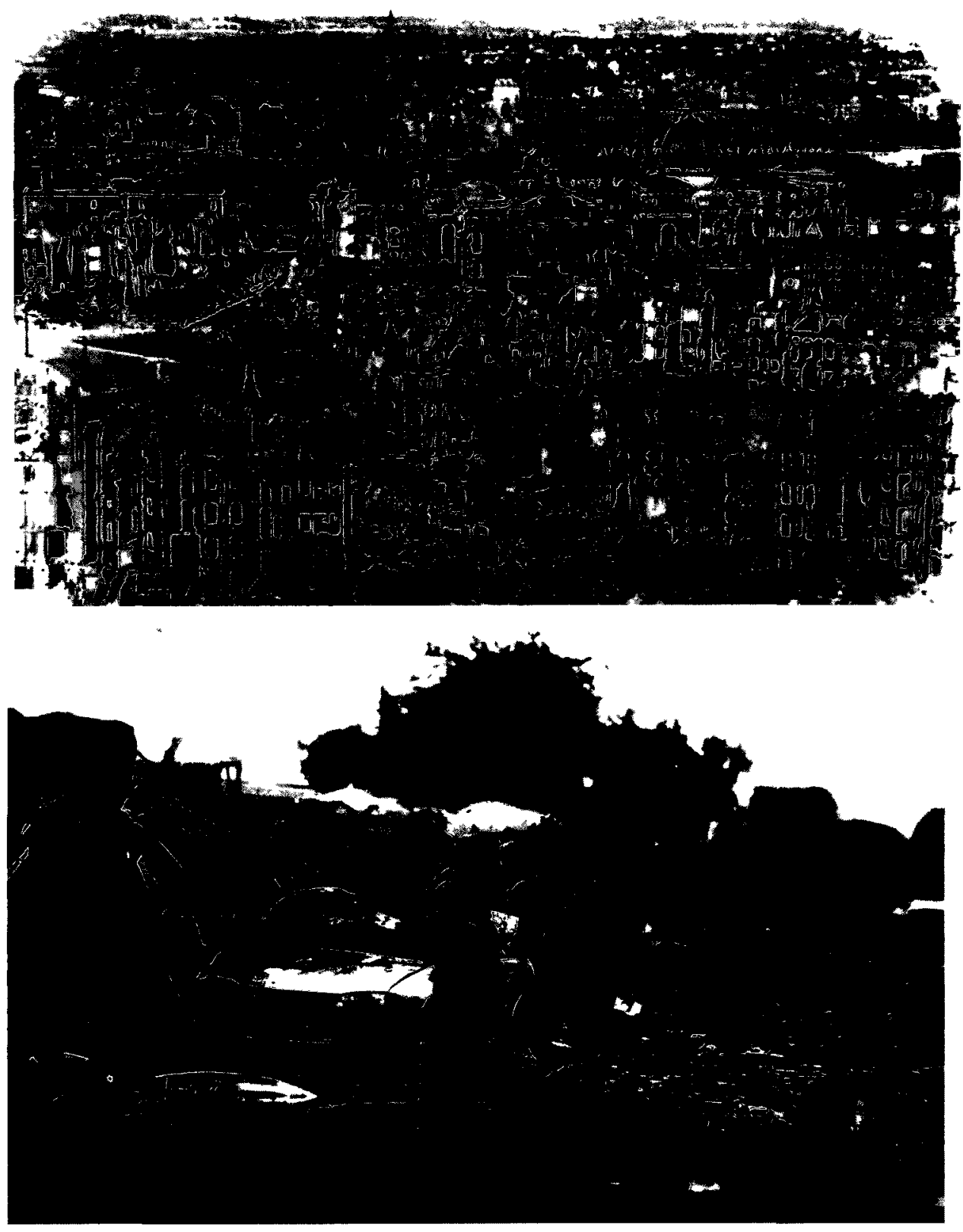

Fig. 4: Ruins of Dresden, Germany, after the Allied bombing raids of February 13-15, $1945 . \quad$ Ignoring targets of strategic importance such as industrial centres, the RAF and USAAF instead dropped some 3900000 lbs. of explosives on the Baroque city centre, destroying fifteen square miles of urban fabric

Fig. 5: US soldiers inspect the aftermath of a suicide bombing in Bayah, western Baghdad, Feb 11, 2009. Shiite pilgrims were the intended targets.

Regardless of who utilizes ethno-cultural identity, the act of turning inward on an identity to fix and harness it for political dominance or subversion can have deleterious consequences, not just for the group in question, but for those who wish to engage in meaningful and gainful negotiation with that group. Ultimately, cultural systems and their ethno-cultural identities tend to become trapped in a 
backward reflection of themselves ${ }^{28}$, a folklorish image subject to repetition as an empty cultural paradigm. To freeze or frame an ethno-cultural identity, or to try and salvage it as an archaeological artifact by arbitrarily assigning some cultural systems as archetypes, is nothing short of projecting a fantasy - a fantasy contrived to conceal the fact that no identity is ever complete. ${ }^{29}$ Architecture is one such cultural system which has been all too often utilized to this end.

\footnotetext{
${ }^{28}$ Niedermuller, Ethnicity, Nationality, and the Myth of Cultural Heritage A European View 248

${ }^{29}$ Baydar, Gulsum The Cultural Burden of Architecture 3
} 


\section{ARCHITECTURE AS A CULTURAL (SYMBOL vS. SYSTEM):}

As we have seen in the map from Atlas of Vernacular Architecture, architecture has often been a primary agent used to fix, frame, fabricate, or salvage a culture from the past for political purposes. Due to its nature as built form, Architecture is a highly visible cultural system, and often a very durable one, enabling it to be readily appropriated as a cultural emblem. In this way, architecture becomes what Bevan calls a "totem" ${ }^{30}$ - a flagship, or billboard - an elaborate form of advertisement or cultural proclamation used to impress or impose one culture over another. This utilization of architecture can be readily seen in many monuments the world over - The Brandenburg Gates, the Notre Dames, San Pietros and Red Squares of our world compete on behalf of the cultures that have appropriated them as symbols, to assert the superiority of one heritage over another. These buildings have come to be seen as sacred cultural artifacts, precious time capsules carrying immutable culture uninterrupted from time immemorial and onwards to eternity. They are thought to contain within them all of the characteristics and embodied knowledge of their epoch and their respective cultures. For this reason, they can attain a status of veneration, approaching sanctity. These buildings must remain as they were, and as they have always been perceived as being, so that the identity stored inside will not become confused or lost altogether. If the emblematic building changes, what would be the implications for the culture it has been appropriated to be an emblem of? To discuss the ramifications of repurposing an emblematic or sacred architecture, the act appropriating a building as such must first be examined.

In his paper, The Cultural Burden of Architecture, Gulsum Baydar relates this act of appropriation through an interpretation of the following passage in Vitruvius' treatise On Architecture:

\footnotetext{
${ }^{30}$ Bevan, Robert. The Destruction of Memory. 8
} 
Both in general and especially in architecture are these two things found; that which signifies and that which is signified. That which is signified is the thing proposed about which we speak; that which signifies is the demonstration unfolded in systems of precepts. ${ }^{31}$

According to Baydar, in this passage that which is referred to as the signified is a building itself - in a liminal state, awaiting signification. In this state, Baydar refers to the built environment as an empty identity category, open to interpretation and revision in its boundless state. The signifier then, is the language that is applied after the fact to authorize it as architecture, thereby assigning meaning to a building. Following Baydar's interpretation of Vitruvius, built objects are not considered architecture until they have been properly authorized by theory, thereby elevating "theorized" buildings above other built fabric. Baydar's' reasoning about the relationship between the signifier and that which is signified has vital implications for architecture and its relationship with culture. By applying theory to buildings, the architect separates architecture from the rest of the built fabric, a primary cultural system intrinsic in the functioning of an ethno-culture. In this mode, architecture is seen merely as a product of culture, and is therefore only symbolic of it. Serving only as a symbol, Architecture is removed from the shifting networks of other cultural systems, fixing its identity and utility - a utility that can only be restored through great discourse and dissent.

Herein lies the problem - When architecture becomes merely an expression of a culture, as an archetype incapable of alteration or reuse due to its symbolic content - it can only fail to be useful to the culture it hopes to symbolize by becoming immediately outmoded. In the words of Cedric Price, influential architect and critic on the subject of heritage and reuse :

This misplaced loyalty to the artefactual trappings of redundant, or at least declining social activities distorts the social usefulness and delight of the

\footnotetext{
${ }^{31}$ Vitruvius, On Arcbitecture, Granger trans. 7
} 
man-made environment... ...An increasing volume of space within which the individual lives and works is being unnaturally preserved not for its usefulness, but for a kinaesthetic pleasure enjoyed by the few, who in turn feel it should be recognized by the many. ${ }^{32}$

In a largely utilitarian, but partly humanitarian sense, Price is decrying the waste of urban space through the ongoing support of what this paper has been calling the emblematic or archetypical building. Because of its imagined symbolic cultural content, it becomes difficult to reassign a meaning or use to the emblematic building, leaving the emblematic building only one option - to continue on as an underutilized emblem of a culture for those who continue to believe it as such. Ultimately, in Price's opinion, society as a whole is victimized by those incapable of parting with the idea of a static heritage.

Of even greater detriment, the emblematic building can exploit the rift in continuity created by its own disassociation with the working systems of culture to project the harmful fantasies discussed earlier. These fantasies are used to shore up the gaps of incomplete identities, and close cultural dialogue to appropriate ethno-cultural identity for political gain. For example, In Germany, Albert Speer utilized architecture as a powerful galvanizing symbol of the past and future power of the Reich, and of the supremacy and predestination of the Aryan race. ${ }^{33}$ The disastrous results of the German desire to restore the past (but imagined) glory of the Reich are well known. In Israel, Government backed archaeologists frequently use architectural relics, appropriated as Judean archetypes to archaeologically salvage a past culture to justify land seizures in the Occupied Territories. ${ }^{34}$ Here, settlement architecture also purposefully mimics local Palestinian vernacular construction, to falsely

\footnotetext{
${ }^{32}$ Price, Cedric. The Square Book. 35

${ }^{33}$ Speer, Albert. Foreword. Albert Speer: Architecture 1932-1942. 213

${ }^{34}$ Weizman, Eyal. Hollow Land. 26
} 
project the appearance of a continuous Jewish cultural presence in the occupied territories through all history, thereby validating the displacement of one culture by another.

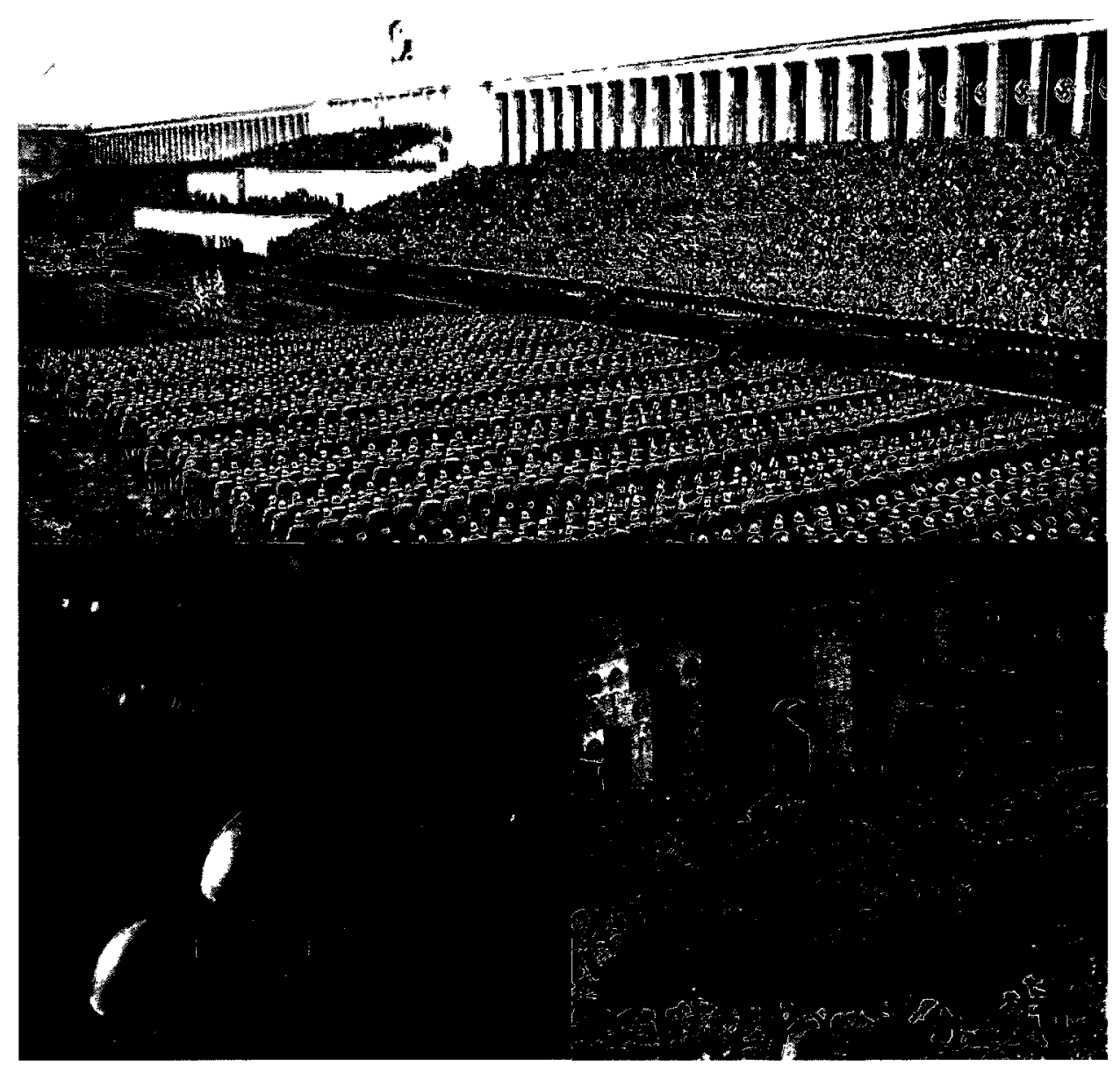

Fig. 6: View of the Fürherpodium from the Nuremburg parade grounds. Designed by Albert Speer, the parade grounds reference the architecture of Imperial Rome and Greece to establish a false tradition of power and permanence dating back to antiquity.

Fig. 7 (Left): Model of the proposed additions to Jewish Quarter, Jerusalem, 1970.

(Architect: Moshe Safdie)

Fig. 8 (Right): Israeli Settlement Bloc in Gilo, West Bank.

When built form is given validation after the fact - through an imposition of meaning and categorization - it can too easily become an agent of "othering", by excluding those built forms that do not relate to its archetypes. This "othering" sets cultural systems - now appropriated as symbols into harmful opposition to one another. These symbolic oppositions are then used to define 
boundaries, with the "good" residing within them, and the "bad" without. ${ }^{35}$ In the words of Bevan, symbolic buildings "are the structures that are erected or destroyed to keep peoples apart, or force them together." 36

Offering an alternative methodology to signification and categorization (which has been shown to be a kind of architectural divide-and-conquer), Giorgio Agamben, In his essay On Potentiality, discusses Aristotle's Metaphysics. According to Agamben's reading, it is not so much the capability to do one desired thing that determines potentiality, but more-so the capability to not-do something. ${ }^{37}$ Agamben is referring to not passing into actuality by avoiding signification and categorization. In this sense, potential is the capability of being and not-being simultaneously. If Architecture is to better serve ethno-cultural identity (which has already established as a fluid construct), it needs to be explored in a state prior to signification, as Baydar would say, as an empty identity category, where its ambiguous state can generate greater potential to catalyze culture, and not frame and fix it. By not naming built form as Architecture, and thereby bestowing on it a greater but artificially constructed significance, built objects can remain just that - objects - things awaiting signification. In this state, the built environment is then defined by the same irreducible lack that has come to inform our understanding of other cultural systems.

Our cities are now rife with heritage buildings, in many ways segregated from the rest of the urban fabric. They are preserved as symbols, as emblems of cultures past, or as life preservers meant to buoy the sinking popularity of a dead ritual - Cathedrals without congregations. So deep is the belief of architecture as a sacred vessel for culture, that the furniture of these cathedrals cannot be moved to

\footnotetext{
${ }^{35}$ Niedermuller, Ethntcity, Nationahty, and the Myth of Cultural Heritage A European View 252

${ }^{36}$ Bevan, Robert The Destruction of Memory 11

${ }^{37}$ Agamben, G1org1o Potentrahtites Collected Essays in Philosophy 182
} 


\section{Heritage Case Study : Ottawa's Portuguese Community Centre as a}

\section{Cultural Symbol, or System?}

Ottawa's Portuguese Community Center is comprised of a small, unremarkable chapel, shoe-horned in an awkward corner condition at the Junction of Main Street and Echo Drive, adjacent to the Rideau Canal, and north of Highway 417. As a piece of architecture, or as an "historic monument - a living witness of age-old traditions" 38 , the church is underwhelming, especially when compared to religious buildings of similar age that have survived the development and densification of Ottawa in the last century. Consisting largely of a single bay of unornamented red brick walls, resting on an aged and oft-repaired rubble-stone foundation, it lacks much of the refinement, detailing, and material splendor of its other aged companions in the city. The mundane, shingled roof sags heavily at the center, and is crowned by an incongruous cupola, just one of many curiosities which pock-mark the surface of the Portuguese Community Center. Six simple, paired, arched windows finished in flaking white paint run the length of the facade on a single sill, filled with uncolored glass with broken panes. Three squat windows in the foundation, which once provided light to the basement below, are now covered in grilling and filled with insulation. The East Wall is comprised of three tall, slender arched windows, divided geometrically in simple square panes of colored glass to provide light to the chancel inside. The Westworks are unceremonious, being comprised of a squat brick stoop added to the front of the church, sporting an asphalt shingled octagonal cupola, and a haphazard patchwork of openings and fixtures. The entry, sitting awkwardly beneath two empty flag holders and a single exposed light bulb, is a large, padlocked double door stained by rusting hinges. It sits upon a crudely poured concrete stair decorated with decaying cast iron hand railings. A second door sits within the concrete

\footnotetext{
${ }^{38}$ Venice Charter, Preamble
} 
foundation itself, curiously floating well above the ground, causing one to inquire where it once landed it where it may lead. The chancellery awkwardly protrudes from the easternmost side of the building, unsympathetically disrupting the line of the roof that encloses the chapel to which it is attached. One window has been replaced to suit as a duplicate fire exit. A brick chimney meanders its way skyward on this elevation of the building, its drunken sway held in check by two tension rods harnessed to the roof. A plywood shed leans in the corner formed by the protrusion of the chancellery from the East Wall, perhaps providing access to the basement. Other notables include a large satellite dish fastened to the westernmost corner of the building, various parking signs for the adjacent businesses, joist hangers from a now absent drive-shed and, everywhere, the mismatched patchwork of replaced and repaired bricks, re-pointed mortar, and crumbling sills, making disrepair the norm. If the criteria used to assess historic buildings for conservation are considered, the continued presence of the disheveled Portuguese Community Center can be considered a rather exceptional curiosity. 


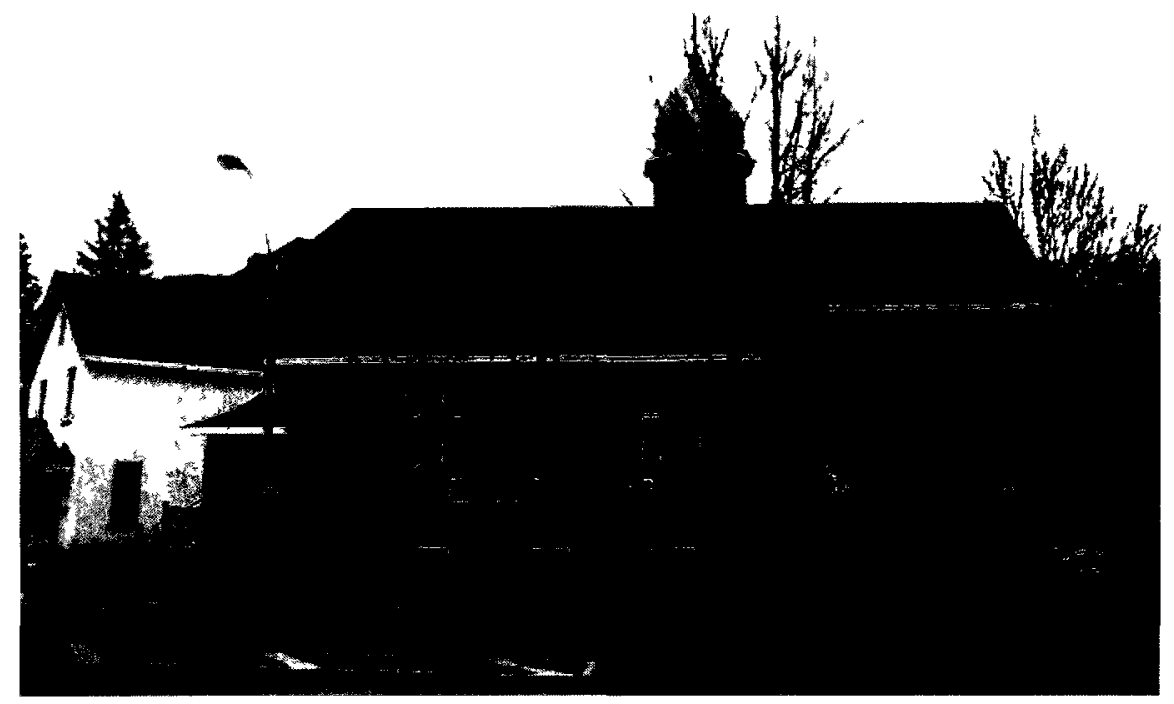

Fig. 10: Portuguese Community Centre at 115 Echo Drive, Ottawa Ontarıo. Looking East

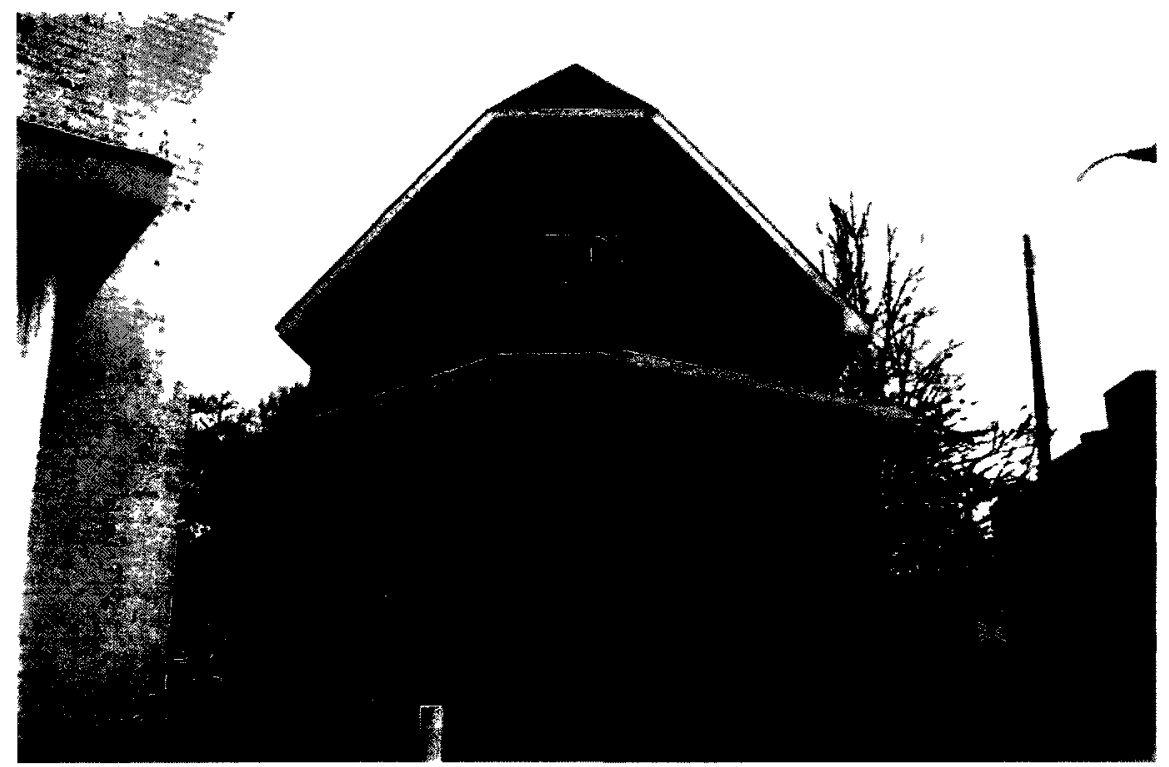

Fig. 11: Portuguese Community Centre at 115 Echo Drive, Ottawa Ontario. Looking South

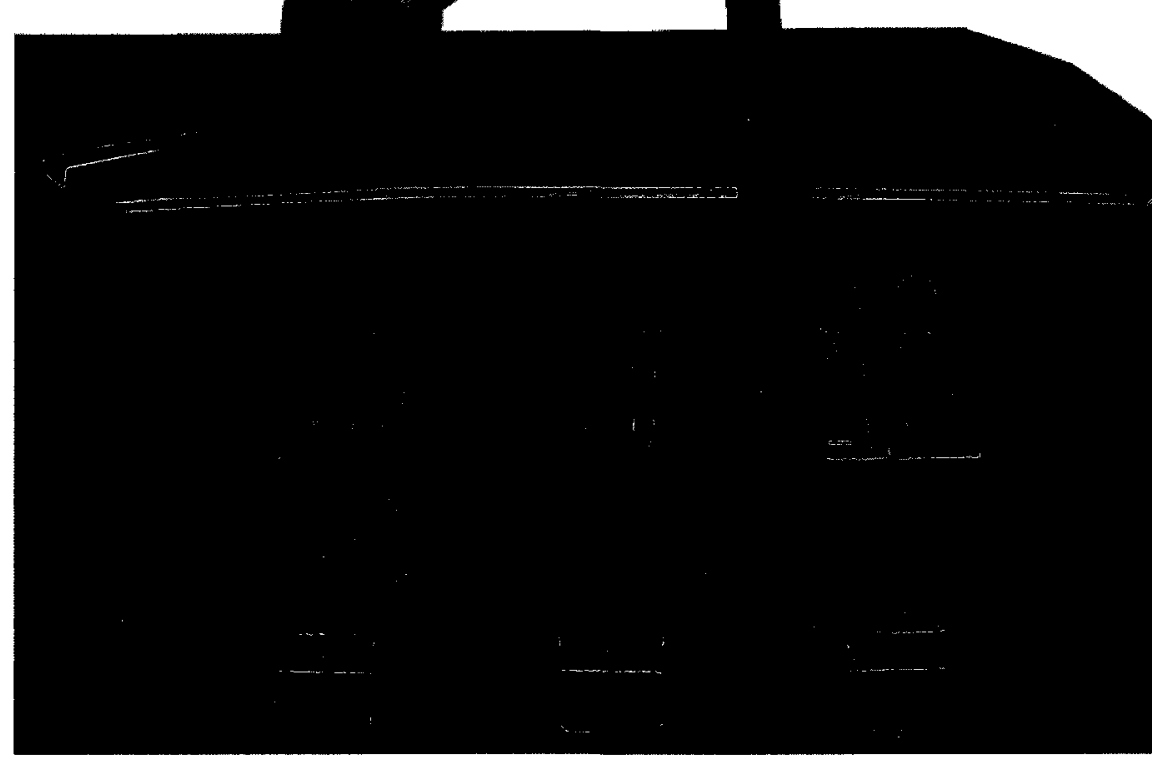

Fig. 12: Portuguese Community Centre at 115 Echo Drive, Ottawa Ontario. Looking West 


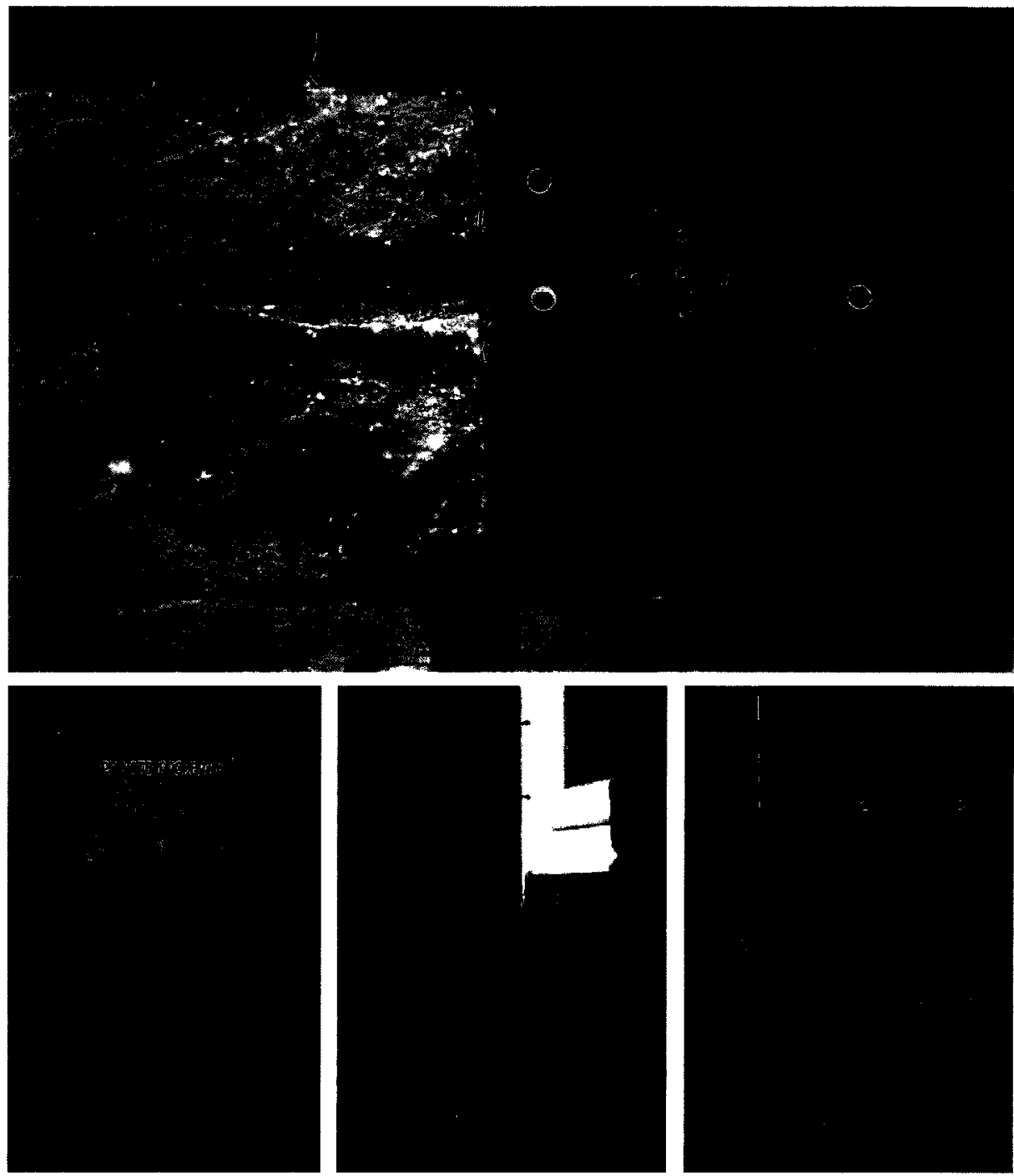

Fig. 13-16: Portuguese Community Centre at 115 Echo Drive, Ottawa Ontario. Palimpsest

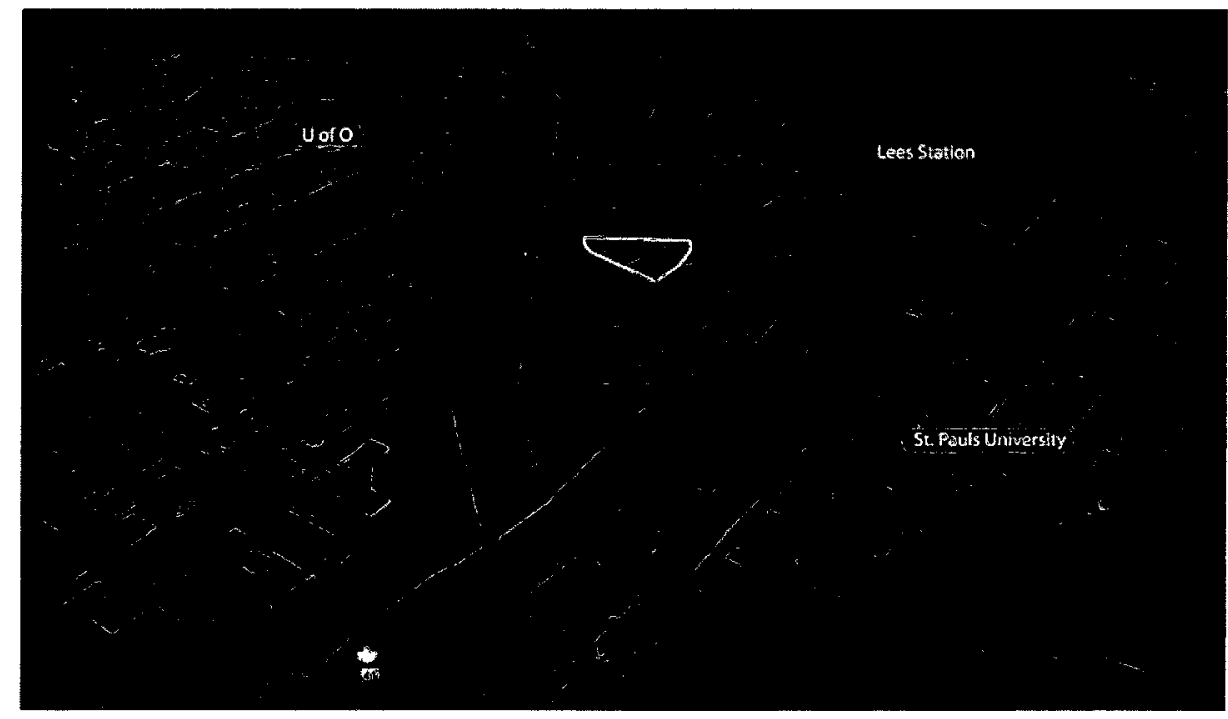

Fig. 17: Portuguese Community Centre, and surrounding site to be developed. 
Heritage conservation as we think of it today is still a relatively new concept, having emerged in the 1960's alongside other movements, such as environmental conservation. One of the most influential documents to emerge from the newly established field was the Venice charter of 1964 , the primary document that has come to inform heritage conservation with respect to the built environment. It states directly in its preamble that built fabric is "imbued with a message from the past" 39 , and that buildings and monuments are "living witnesses to age old traditions"40, implying that culture is symbolically stored as content within them. This view that tradition is somehow embodied within the physical building itself has led to a particular focus on the material elements on a site, as the repositories of significance for the place. Such a theory lends itself, or even forces a typical treatment on historical buildings in a context of urban renewal - what Geertz would call "turning them in to folklore and collecting them"41 - an action that fixes and frames the interpretation of buildings and thereby museumizes them in an attempt to pristinely conserve the heritage stored inside. Therefore, heritage conservation typically lends itself to those building that aesthetically please - those buildings we elevate to the status of symbol through our preoccupation with the facade.

To be deemed "heritage", and thereby worthy of conservation, buildings must typically be elevated to archetypical status, and deemed exceptional in their physical make-up, which the Portuguese Community Center is not. If authentic heritage resides emblematically within the very stones and timbers of buildings, within the craftsmanship of its detailing, and the careful maintenance of its original state, then the Portuguese Community Center could not be said to have any heritage value at all. If this is so, then what has allowed the Portuguese Community Center to survive to this day, and

\footnotetext{
${ }^{39}$ Venice Charter, Preamble

${ }^{40}$ Ibid

${ }^{41}$ Geertz, Clifford. The Interpretation of Cultures, 29.
} 
what - if anything - could validate its continued presence at 115 Echo Drive? A visit to the City of Ottawa archives emphatically provides an answer to both of those questions.

By examining a series of archived newspaper clippings and black and white photographs, it is clear that at no point could it be said that the chapel at 115 Echo Drive was an embodiment of Portuguese cultural practices, or a sacred repository of Portuguese rites and traditions. The building that has survived to the present day was constructed in 1919 to provide for a growing Anglican congregation that had spilled beyond the limits of its primary church (built in 1877), now absent, likely being cleared from the portion of the site where a two storey office building now stands. ${ }^{42}$ Importantly, having been composed as an auxiliary to another building, it would seem that utility and affordability were of primary concern in the design of the chapel, and not iconography and decoration. After the removal of the primary Anglican church, the chapel was purchased by a German Lutheran congregation. After the Lutheran congregation purchased land and built a larger church elsewhere, it was followed by a Seventh Day Adventist congregation. The church continued to change hands until its eventual purchase by the Portuguese community of Ottawa, with congregations as varied as Greek Orthodox, Pentecostals, and Ukrainian Orthodox. ${ }^{43}$ The exact purchase date by the Portuguese community is unknown, but it was sometime after the drafting of the City of Ottawa's Fire Insurance maps of $1954^{44} \mathrm{~A}$ newspaper article announcing the completion of a new Ukrainian Orthodox Cathedral could put the purchase of the chapel on Echo Drive somewhere in the years 1963-1964,

\footnotetext{
42 Earliest found map of location is a fire insurance map from 1954 It indicates a large vacant lot to the south of the existing chapel, where a two storey office building now stands

${ }^{43}$ Rogers, Marion C Church of the Week Ottawa Journal June 30, 1978

${ }^{44}$ The Ottawa Fire Insurance Maps of 1954 note that the Chapel at 115 Echo Drive belonged to the Ukrainan Orthodox congregation at that time See Appendix A

${ }^{45}$ Rogers, Marion G Ukrainzan Ortbodox Cathedral, Ottawa Journal, 1979 (date unknown)
} 
and certainly before the year $1978 .{ }^{46}$ Sole ownership of the property by the Portuguese community has far from stopped the carousel of religious groups that have used the chapel since its inception. The building is currently used by a Catholic group celebrating the Latin Mass. The Chapel can be said to have housed a different congregation, on average, every 11 years.

It would appear that the answer as to why the chapel on 115 Echo Drive has been so successful at both avoiding demolition for so long while attracting new and disparate communities, is that is much closer to what Baydar called an empty identity category, and not a monumental piece of architecture. The great potential caused by the absence of symbolic ornament, and its utilitarian history has allowed the chapel at 115 Echo to be filled with a new and different significance as necessitated by each of its various user communities.

Though the chapel at 115 Echo Drive may well be unkempt, unpretentious, and of little interest with regards to contemporary heritage conservation practices, it has an exceptional and valuable history that deserves recognition. The eclectic forms, banal materials and unsympathetic alterations that scar the face of the chapel form a palimpsest - layered evidence of a utilitarian cultural system that is revisable as needs dictate, and not a sacred symbol of an undying ethno-cultural heritage. Serving as such, the chapel at 115 Echo drive has been an invaluable tool for marginalized and underrepresented ethnic immigrant groups that have come to Ottawa. Fleeing poverty, war or oppression, the chapel at 115 Echo has been, and continues to be an affordable and accessible refuge in which liminal communities can begin constructing their identities as they negotiate within the new societal conditions in which they find themselves.

${ }^{46}$ Rogers, Marion C. Church of the Week. Ottawa Journal. June 30, 1978 


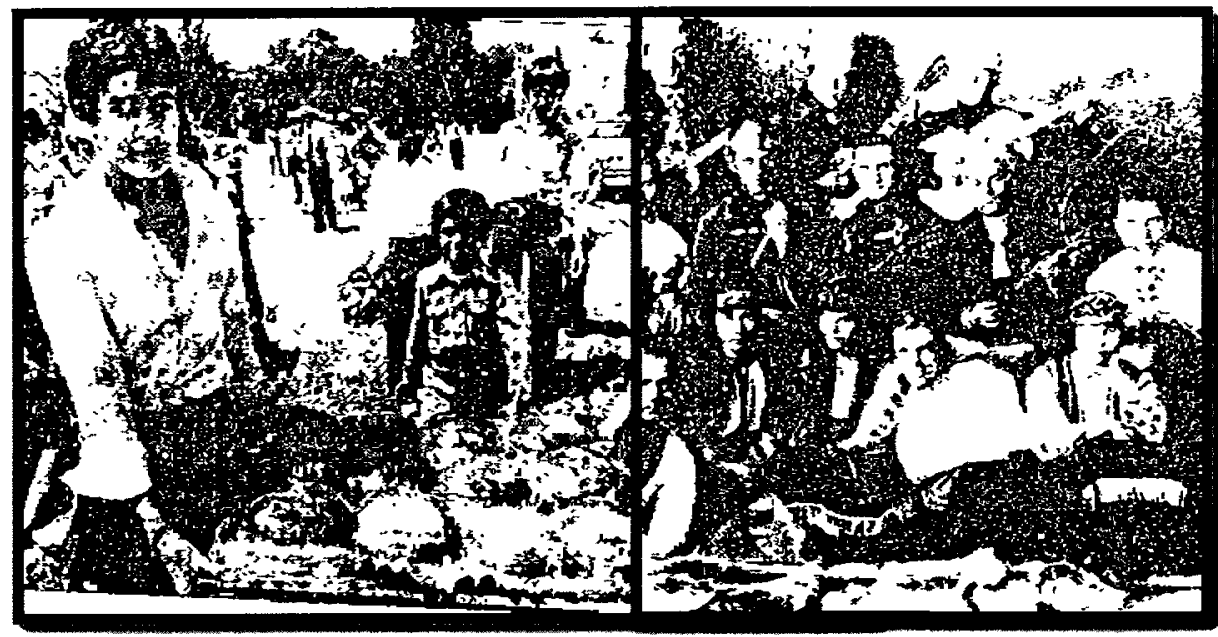

Fig. 18 (Left): Portuguese congregation celebrate Pentecost Sunday feast. (1979)

Fig. 19 (Right): Ukrainian Orthodox congregation poses for a photograph in traditional garb. (1954)

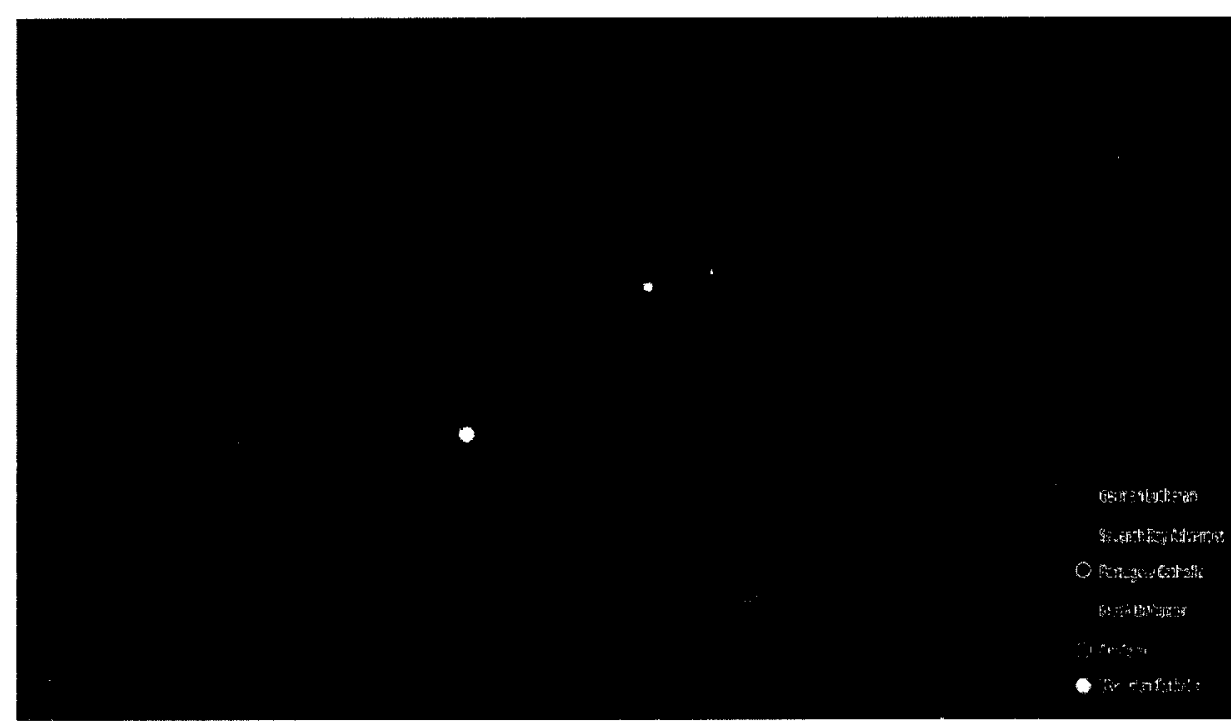

Fig. 20 (Right): Map documenting the growth and dispersal of various congregations from the Chapel at 115 Echo Drive. 


\section{Re-Thinking Heritage - A Problem of Potential}

This thesis now comes to a point where it is pressed with the task of deciding some sort of future for the Portuguese Community Center at 115 Echo Drive. Initial thoughts of preserving the site as a generator or negotiation center of culture for the Portuguese Community are undermined by the fact that the building has already been abandoned by the Portuguese Community for a new building much further from the city center. Furthermore, investigations as to which pieces of the chapel are symbolic kernels of Portuguese culture provided marginal evidence, as inhabitation of the Chapel by the Portuguese community proves to be but one small layer of sediment.

If the Portuguese Community Center cannot be said to be authentically Portuguese, exactly what stage of occupancy of the chapel can be said to be the most authentic heritage, the one worth protecting? Is it even possible, or morally right to make such distinctions? A paper titled Theorizing Heritage, written by Barbara Kirschenblatt-Gimblett provides some direction through her insights in to the nature of heritage itself.

As a folklorist who began her academic work in the 1970 's, she states that she was trained to study tradition, as tradition is still thought to be as defined by most popular dictionaries. This definition is taken from Wikipedia, the world's most popular, but academically maligned encyclopedia. It states that tradition "is a tool to preserve a wide range of culturally significant ideas, specific practices and the various methods used by distinct cultures," ${ }^{47}$ or in other words, a force that is resistant to change. Kirschenblatt-Gimblett makes reference in her paper to a book titled The Invention of Tradition, by

\footnotetext{
${ }^{47}$ http://en.wikipedia.org/wiki/Tradition
} 
Eric Hobsbawm and Terence Ranger, that challenged this very definition of tradition, and the viability of her field of Folklore studies. In its introductory chapter, Hobsbawm and Ranger make this pertinent statement:

insofar as there is such reference to a historic past, the peculiarity of "invented" traditions is that the continuity with it is largely factitious. In short, they are responses to novel situations which take the form of reference to old situations, or which establish their own past by quasi-obligatory repetition. ${ }^{48}$

This interpretation of tradition sounds resonates with Niedermuller's writings on cultural heritage, or Geertz's Interpretation of Culture, both of which state in their own way (now borrowing again from Baydar's words), that culture consists of a combination of systems constructed in an ambivalent space of enunciation and a discontinuous time of translation and negotiation. ${ }^{49}$ The position taken by Hobsbawm and Ranger, that tradition is made (though not totally fabricated), led KirschenblattGimblett to take a similar stance when writing Theorizıng Heritage :

Heritage, for the sake of my argument, is the transvaluation of the obsolete, the mistaken, the outmoded, the dead, and the defunct. Heritage is created through a process of exhibition (as knowledge, as performance, as museum display). Exhibition endows heritage thus conceived with a second life. ${ }^{50}$

By this definition heritage itself is a new mode of cultural production that produces something entirely new that merely has recourse to the past ${ }^{51}-$ it is not the past itself. Heritage then cannot, and will never be an authentic vision of the past. What is even more important to note is that for something (a building, neighborhood, dress, festival, dance, feast etc.) to become "heritage", it must first fall out of use or favor by the culture to which it used to be systemically linked to. Heritage is therefore a layer applied after the fact in a futile attempt to reconcile the utility of an outmoded cultural system. This

\footnotetext{
${ }^{48}$ Hobsbawm, Erich and Ranger, Terrence The Invention of Tradition pg 2

${ }^{49}$ Baydar, Gulsum The Cultural Burden of Architecture 3

${ }^{50}$ Kurschenblat-Gımblett Theortzing Heritage 369

${ }^{51}$ Ibld 370
} 
attempt is made by means of appropriating the outmoded system as a symbol of culture, allowing it to generate attention and capital, but ironically removing it further from the ongoing dialogue of cultural systems. If the chapel at 115 Echo Drive were to be treated in such a way, as a heritage landmark, perhaps an "Open Air Museum of Immigration", its meaning would become fixed in this way, spoiling its potential to be a catalytic generator of culture in Ottawa for future immigrants. If the chapel is still finding use as a cultural safe-house of sorts, why should its potential to do so be annulled by labeling it as heritage, thereby removing it from the sphere of everyday utility? The relatively recent inclusion ${ }^{52}$ of "cultural landscapes" in to the canon of applicable heritage sites raises an interesting dilemma that gives weight to the argument for a continued presence of the Chapel at 115 Echo Drive in downtown

\section{Ottawa.}

In 1992, UNESCO declared that "cultural landscapes" were now subject to assessment and protection, allowing them to be designated and protected as heritage under appropriate legislation. These new heritage landscapes posed problems for both conservationists and existing heritage criteria, due to their inherent traits of ongoing change and evolution. The rigid criteria used to evaluate the built environment was incongruous and insufficient to the dynamic and ephemeral qualities inherent within landscapes. Sites such as Civil War battlefields, farming districts, and managed woodlots necessitated a rethinking of the status quo. The declaration that resulted from the ICOMOS meeting in 1996 in San Antonio sates that:

dynamic cultural sites, such as historic cities and cultural landscapes, may be considered to be the product of many authors over a long period of time whose process of creation often continues today. This constant adaptation to human need can actively contribute to maintaining the continuum among the past, present and future life of our communities. Through them, our traditions are maintained as

\footnotetext{
${ }^{52}$ UNESCO World Heritage Committee Operational Gudelınes for the Implementation of the World Heritage Convention of 1992 was the first point at which landscapes were recognized as viable heritage sites
} 
they evolve to respond to the needs of society. This evolution is normal and forms an intrinsic part of our heritage. Some physical changes associated with maintaining the traditional patterns of communal use of the heritage site do not necessarily diminish the site's significance and may actually enhance it. Therefore, such material changes may be welcome as part of on-going evolution. ${ }^{53}$

This declaration mirrors the one that opened this paper - that authenticity lies not in any one facet of a site's history that we may chose to package and sell as heritage, but in the changes that occur over the passage of time itself. To be authentic with regards to a place or building is to focus on the dynamic, and to move away from questioning how to best maintain the integrity of the fabric (seen as a timeless cultural symbol) toward how to best maintain the integrity of the processes which gave form and substance to the fabric instead. ${ }^{54}$ By this reasoning, the chapel at 115 Echo Drive need not surrender any of its current utility to new citizens of Ottawa - rather, its potential can be heightened through sympathetic and additional construction and programming. The chapel's continued existence will be justified by the addition of another layer of architectural sediment, one that will serve to intensify the Chapel's present use as a working tool for those in greatest need of renegotiating their identity in a new context - thereby maintaining the integrity of the processes which gave form to its fabric. This addition will be called the Culture Generator.

\footnotetext{
${ }^{53}$ ICOMOS, InterAmerican Symposium on Authenticity in the Conservation and Management of the Cultural Heritage Declaratron of San Antonio Section B - Article 5

${ }^{54}$ Stovel, Herb Foreword Working towards the Nara Document, 105-106
} 


\section{Generating Culture: Enabling Ottawa's Refugee Population}

Of all the hybrid identity groups mentioned by Pieterse and others, such as immigrants, emigrants, migrant workers, and dual citizens, none face the social and identity challenges of the government sponsored refugee. To meet these challenges, the Chapel at 115 Echo Drive will again be modified to endow its services on a much larger population than it has in the past - the displaced persons of the world who eventually come to make Ottawa their home.

As a signatory of the United Nations Convention on Refugees, Canada is a nation committed to protecting the stateless, not just by offering temporary refuge to those in need, but by offering government sponsored social support and permanent resettlement if desired. Of the 8000 immigrants who permanently settle in Ottawa each year, approximately 2000 are refugees. ${ }^{55}$ Although immigration is often vital for the health of a city and growing its economy, such a large number of refugee migrants places a huge strain on Ottawa's social systems, and great strain on the refugees themselves.

Since Canada's refugee legislation is now based largely on compassionate and humanitarian sympathies $^{56}$, government sponsored refugees gain access to Canada mostly on criteria of compassion, and not on criteria of compatibility or economic potential. For this reason, the refugee populations of Canada are immediately disadvantaged upon their arrival, lagging behind selected immigrants ${ }^{57}$ in

\footnotetext{
${ }^{55}$ Statıstics Canada Facts and Figures Statistical Overview of the Temporary Restdent ad Refugee Clatmant Population 200229

${ }^{56}$ Beiser, Morton, DeVoretz, Don, and Pivnenko, Sergyy The Economic Experience of Refugees in Canada, from Research on Immigration and Integration in the Metropols 2

${ }^{57}$ Accordıng to the CIC, selected immigrants are divided in to four classes Business, Economı, Family Class, and Skılled Worker, based on their perceived utility to the Canadian Economy All have been found to outperform designated refugees in every economic category See note 57, Beiser and Morton

http //secure vec bc ca/citizenshıp immigration-terms cfm
} 
nearly every measurable economic and social category. ${ }^{58}$ The majority of designated refugees who attain Canadian citizenship do not speak either official language, with the vast majority having attained only a secondary education at best, making many basic needs such as employment, housing, and social networks difficult to attain on arrival. ${ }^{59}$

Due to these language and education deficits, the refugee experience is largely typified by reliance on outside sources for income such as government or private sponsorship, forming a long term dependence on social services such as employment insurance and social welfare. Even in the peak years of a worker's productivity ( 21 - 48 years of age), designated refugees are twice as likely to receive long term welfare assistance and employment insurance than all other immigrant classes. ${ }^{60}$ According to one study, only $52 \%$ of all refugees studied between the ages of 20 and 64 found steady, secure employment within the 17 year study period $(1980-1997)^{61}$. This culture of dependence and workforce inexperience makes long term poverty a disturbingly common issue, with the average refugee designate earning only $70 \%$ of the Low Income Cut-Off level. ${ }^{62}$

The economic disparity between refugees and other landed immigrants is only one piece of the much larger problems of adaptation and negotiation. Although displaced newcomers who arrive in Canada are relieved in finding safety from persecution, new and challenging obstacles soon present themselves, such as living in unsafe neighborhoods, a lack of social networks, isolation, discrimination, and

\footnotetext{
${ }^{58}$ Beiser, Morton, DeVoretz, Don, and Pivnenko, Sergiy The Economic Experience of Refugees in Canada, from Research on Immigration and Integration in the Metropolis 30

${ }^{59}$ Ibid 8

${ }^{60}$ Ibid 27

${ }^{61}$ Ibid 28

${ }^{62}$ Ibid 26
} 
emotional trauma. ${ }^{63}$ Participation in a new society becomes difficult or disrupted by the stresses resulting from fleeing the country of origin, cultural perceptions about education, the lack of opportunities presented, or the frequency of bureaucratic barriers encountered. The chronic stress resulting from both fleeing one's own cultural context and quickly being forced to negotiate a highly dissimilar one $e^{64}$, causes disruption in refugee's abilities to reappraise their lives, and explore new ways of thinking and acting - to negotiate new identities in an alien context. ${ }^{656667}$

It has already been noted by Niedermuller, Geertz, and others, that ethno-cultural identities have always been seen to adapt and reinvent themselves within the fluctuating societal conditions and power structures from which they derived. Cultural change by itself then, is not so much the problem that needs to be addressed in the refugee scenario, but the frightening and alienating pace at which cultural change occurs to the displaced. The dislocation suffered from fleeing one's home country is clearly unavoidable and must be taken as a given in this exploration, but the additional challenge of being thrust amongst a dissimilar social structure could certainly be mitigated by how refugee "integration"68 is systemically handled.

\footnotetext{
${ }^{63}$ Magro, Karen Bunlding bridges to soctal inclusion researcbing the experiences and challenges of the lost boys and girls of Sudan community in Winnipeg 2

${ }^{64}$ CBC News Online, Forum Addresses Depression in the Somali Community March 5, 2010 Found at $\mathrm{http} / / \mathrm{www} \mathrm{cbc} \mathrm{ca} / \mathrm{canada} /$ ottawa/story/2010/03/05/ott-somali-depression html

${ }^{65}$ Magro, Karen Bullding Bridges to Social Inclusion Researching the Expertences and Challenges of the Lost Boys and Gurls of Sudan Communtty in Winnipeg 2

${ }_{66}^{66}$ Taylor, Donald D Vietnamese Refugee Adaptations in Three Contexts A Life History Approach 146

${ }^{6 /}$ Ervin, Alexander M and Welın, Louse Refugee Chents and Social Service Agencies Some Aspects of Cross-Cultural Misunderstanding 182

${ }^{68}$ Integration is the predominant word used in literature not just in studies and Government Departments such as the CIC, but also in community settlement organizations as well, such as the 'Somalı Integratıon Center"

See Derwing, Tracy, Krahn, Harvey, Mulder Marlene, and Wilkınson, Lorı Educated and Underemployed Refugee Integration into the Canadian Labour Market
} 
In his research Culture and Bunlt Form - a Reconsideration, Amos Rapaport makes reference to supportive environments, which he describes as assisting to modulate and manage rates of change within globalized cultures. ${ }^{69} \mathrm{~A}$ supportive environment can be established by critically asking "what is it that needs to be supported?". By identifying "core" cultural systems that carry greater meaning and continuity within an ethno-cultural identity, the negative effects of isolation can be mitigated, allowing for syncretism and constructive adaptation instead. Using a local example, the Somali Centre for Family Services demonstrates that it is not so much the "peripheral"70 practices of a culture (dance, dress, and tribal colors), but systems such as family and social networks, and communication and negotiation that are truly vital in the constructive adaptation to new societal conditions. Having been initially focused on "preserving Somali Culture and Heritage", the Somali Centre for Family Services has now realigned itself to foster the core systems of greatest need - housing, counseling and language services. ${ }^{71}$

If the current system of government sponsored refugee integration permeates a culture of dependence, isolation, degradation, and passivity, what then can be provided through a built intervention to create a culture of self reliance, communication, prosperity, and engagement?

The Portuguese Community Centre serves to inform that any addition to the site must be just as adaptable and utilitarian, if it is to be of any service to the refugees that would use it. Based on the needs of refugees themselves, and the documented strain on the social welfare and housing services of Ottawa, the potential of the site must be intensified to provide for a supportive environment to instill

\footnotetext{
${ }^{69}$ Rapaport, Amos Culture and Bunlt Form - a Reconsideration pg 201

${ }^{70}$ Both Eliot and Rapaport refer to some cultural systems as being more vital than others - a core of beliefs and practices that are indispensible, surrounded by a shell of "shallow", changeable practices

See, Eliot, T S After Strange Gods 18, and,

Rapaport, Amos Culture and Bult Form A Reconszderation 180

${ }^{71} \mathrm{http} / / \mathrm{www}$ somalıfamilyservices org/about html
} 
stability, sense of place, and comfort within the refugee population, so that healthy growth of identity may follow. If the negative manifestations of ethno-cultural identities arise in spaces of marginalization and exclusion, then the additions to 115 Echo Drive should instead intensify exchange and dialogue between refugees and the new societal conditions in to which they are thrust, thereby empowering refugees through enabling ${ }^{72}$ them.

There are of course, problems encountered when taking such an approach. How can one specify what to build, if such specificity has been seen time and again to cause prohibitive restraints upon buildings and their users? To assign definitive programs is to frame and categorize, and to frame and categorize is to exclude possibilities. To be truly potential, a building must be as free to not-do one thing, as to do another. Being unable to anticipate which cultural group may next utilize the chapel, and not being a member of that group ourselves, it would be impossible to design for the needs of one group without constricting the potential of the group that may follow.

One solution to this dilemma may be to simply avoid specification - For this reason, I propose to let the building constantly re-purpose itself, just as the Chapel has throughout its history. To this end, accounting software was utilized to process a database of key terms, thereby generating infinite programs through randomized automated serial assignment ${ }^{73}$. Doing so created disjunctive, anomalous, and often contradictory possibilities that combine and recombine in a multitude of ways, allowing for an unlimited amount of uses over time. The following terms are the results from two of such random samples.

\footnotetext{
72 This term has been borrowed from Ryston Landau's reflections on Cedric Price' life work, titled A Philosophy of Enablement. See: Price, Cedric. The Square Book . 11

${ }^{73}$ Using a program titled ACL (a data analytics software) a database of terms was entered in to spreadsheet of 3 data fields. Utilizing ACL's sampling feature, a random serial number was assigned to each of the terms in the data fields, thereby assembling them at random. This process could be repeated an unlimited number times, with an identical data field to produce different results each iteration.
} 
1.6 : Ethno Anticipatory Dwelling Kitchen / Anticipatory Ethno - Dwelling

1.1 : Network Hybrid-Enclosure

1.7 : Hyper-Express Hybrid Exchange

1.10 : Indeterminate Dialogue Machine

$1 . .31$ : Dynamic Ethnic Facts Pavilion

1.26 : Difference Exchange Network

$1.20:$ Juxtaposed Habitat Manufactory

1.13 : Public Inter-Space Practice

1.17 : Spontaneous Experiment Dwelling Center

1.18 : Dwelling System Infrastructure

1.28 : Hybridized Religion System

1.9 : Techno-Boundary Interchange

1.13 : Diversified Neighbourhood Shelter Infrastructure

1.21 : Language Laboratory Building Tool

1.11 : Authentic Community Culture?

1.4 : Liminal Ritual

1.12 : Cultural Interpretation Mall 
2.5 : Inter-Scalable Research

2.24 : Experiment Pavilion

2.32 : Knowledge Dwelling System

2.12 : Situated Knowledge Program

2.26 : Integral Exchange Practice

2.3 : Indeterminate Shelter Catalyst

2.16 : Radically Diversified Social Space

2.36 : Ethno-link Playground

2.18 : Collaborative Information Co-Manufactory

2.12 : Spontaneous Habitat Mall

2.19 : Boundless Community Generator

2.29 : Religion Exchange Infrastructure

2.4 : Dynamic Cultural Collusion

2.20 : Hybrid Manufactory

2.8: Anticipatory Ethnic Practice Lounge 
This is not to say that these generated terms are the program or the title of the building itself, for they serve as an analogue for how the building itself should function - as a system or infrastructure which supports or catalyzes constant reconfiguration. The contradictory and double meanings that result from this exercise indicate an elusive and constantly fluctuating functionality - or in Agamben's terminology, a richness in the potentiality of the building to "do", and "not-do".

Dangerously, by this logic, there exists a convenient excuse for the architect to do no designing at all why should one assign materials, programs and capacities, if such decisions may only inhibit the future possibilities of the Culture Generator? How is it possible to design for the specifics of one ethnocultural group without inhibiting another? Revisiting Agamben's On Potentiality serves to give direction in light of this apparent dilemma.

In his introduction, Agamben differentiates between two different types of potentiality, the generic and the specific. ${ }^{74}$ In the context of this thesis, the generic can be likened to the potentiality of the newly arrived refugees who are meant to utilize the Culture Generator. The refugee's lack of education, professional training, and language (when compared to the host community, Ottawa) presupposes a high degree in variance as to what they may someday do, or not-do. By contrast, The specific potential, in the circumstances given by Agamben, exists in things or beings with a faculty, which is described by Agamben as a "having". In this state, things or persons are potential in that they have the ability to do, or not-do based on an acquired knowledge. Agamben, for instance, states among his examples that the architect has the potential "to build" through his or her education as an architect. If we ask the question "what are the specific faculties a refugee need attain upon

\footnotetext{
${ }^{74}$ Agamben, Giorgio Potentıalities Collected Essays in Phrlosophy 179
} 
resettlement?", it becomes clearer what must be imparted on the refugees through the use of the Culture Generator if they are to be enabled to negotiate a prosperous existence in a new society.

The present protocol for housing newly arrived refugees is to temporarily place them in a motel or hostel, while more permanent accommodations can be found in the rental housing market. ${ }^{75}$ During this initial residence, refugees are taken by volunteers from local settlement programs to be enrolled in various government registries such as Health and Social Insurance, and to buy necessities such as furniture for a future apartment, and clothes suitable for the Canadian climate. ${ }^{76}$ In general, and in Ottawa especially, this initial temporary residency has lengthened substantially due to a chronic shortfall in subsidized or affordable housing. ${ }^{778}$ At present, the city of Ottawa has a 5 year waiting list for its stock of 25000 subsidized units ${ }^{79}$. To help alleviate this problem, social workers at settlement agencies have developed contacts with various landlords who possess affordable rental properties across their respective cities of responsibility, so that a stock of cheaper accommodations may be available to refugees upon resettlement. Although some officials within Ottawa's social services have expressed a need for affordable housing specific to sheltering the refugee population, the initial capital cost of doing so has been prohibitive. ${ }^{80}$ The end result of these shortages is that refugees are forced to live wherever there is an affordable vacancy, and not necessarily in an environment more suitable to their resettlement. If shelter currently serves as a protagonist of alienation and segregation amongst the refugee population, thereby spoiling their potential as new citizens, could it not instead become a primary agent in their successful resettlement?

\footnotetext{
${ }^{75}$ Crossley, B Tusha Fundamentals of Government Sponsored Refugee Settlement 161, 163

${ }^{76}$ Ibid 162

${ }^{77}$ Redmond, David, and Associates, Canadian Mortgage and Housing Corporation - Research Division Refugee Housing Information Needs Research Conducted in the Region of Niagara 28

${ }^{78}$ Sabourın, Dan Personal Interview March 25, 2011

${ }^{79} \mathrm{http} / / \mathrm{www}$ ottawa ca/resıdents/housing/social_housing/index_en html

${ }^{80}$ Sabourın, Dan Personal Interview March 25, 2011
} 
Studies show that refugees must quickly develop the faculty to communicate ${ }^{81}$, and the knowledge of a skill or trade in demand ${ }^{82}$, so that they can feel a measure of belonging and independence and support themselves financially. Unfortunately, it has been shown that the inherent difficulties in acquiring these skills are compounded by the depression and stress so often incurred on the displaced..$^{838485}$ Refugees are robbed of the potential to negotiate a new existence due to a deleterious mental state induced by their past experiences, and their present disconnection from the culture in which they have arrived - two symptoms that can be ameliorated through a more supportive housing environment.

Although many refugees feel they receive ample "material" and "instrumental" support in their relocation to $\mathrm{Canada}^{86}$ (this includes financial assistance and counseling), host communities are unable to deliver what is most crucial to the displaced - a culturally responsive support system. The socioemotional support of individuals who have lived through similar experiences and can thereby provide affection and sympathy to newly arrived refugees is crucial if they are to be emotionally and mentally capable of tackling the daunting task of learning a new language and finding employment in a new context. ${ }^{87}$ If the Culture Generator is to improve upon the current results of refugee "integration" as it now stands, it can first provide a common housing infrastructure for refugees to co-habit, subverting the present systems which inhibit their potential for interaction by scattering refugees about the greater Ottawa area.

\subsection{Indeterminate Shelter Catalyst - Diversified Neighborhood Infrastructure}

\footnotetext{
${ }^{81}$ Van Esterık, Jon L Communicatıve Clatms in a Refugee Program Case Study of an Anthropologist as a Service Provıder 187

${ }^{82}$ Ibid 188

${ }^{83}$ Ibid 192

${ }^{84}$ Ervin, Alexander M and Welın, Louise Refugee Chents and Social Service Agenctes Some Aspects of Cross-Cultural Misunderstanding 182

${ }^{85}$ Fuchs, Linda Factors Affecting the Level of Happiness Among Southeast Astan Refugee Women in Saskatoon 150-151

${ }^{86}$ Fuchs, Linda Factors Affecting the Level of Happiness Among Southeast Asian Refugee Women in Saskatoon 155

${ }^{87}$ Ibid 156
} 
This housing infrastructure is to be comprised of two parts - a short term hostel (Indeterminate Shelter Catalyst) of approximately 25 rooms, and an indeterminate number of short term rental units (Diversified Neighbourhood Shelter Infrastructure). The indeterminate shelter catalyst will be designed for the short intermediary stage prior to moving in to a sponsor's home or a rental unit, either within the Culture Generator, or without.

The Shelter Catalyst would provide private rooms suitable for a variety of household configurations such as individuals, couples, and families, with each having its own kitchenette and bathroom facilities. These units would be of a static configuration, and designed primarily to provide privacy and calm after the uncomfortable life of refugee camps, and the invasive procedures endemic in the refugee application process. Once initial settlement acquisitions and inquiries have been made, refugees may transition to the Short term rental units on site. These units will have to be approached with a greater criticality, as they will be the most intrinsic piece in the supportive environment that is the Culture Generator.

Lawrence points out in his reflection on the cultural suitability of housing, House Form and Culture: What Have we Learnt, that there has been an exceptional oversight of societal values in the fabrication of residences in the globalized world, with particular inattention to the rapidly changing composition of households and families - a condition that holds particularly true to the displaced. ${ }^{88}$ In his opinion, the values of residents concerning the use of domestic space and facilities are not taken in to account in the design and composition of housing stock - that the interrelations between the societal context and its embedded processes are not being associated in conjunction with personal values. ${ }^{89}$ As a result, housing has been compromised as a cultural system within the greater societal context, robbed of its

\footnotetext{
${ }^{88}$ Lawrence, Roderıck J House Form and Culture What Have we Learnt in Thirty Years? 59

${ }^{89}$ Ibld 59
} 
potential, and fixed in actuality by largely economic imperatives. The resulting human costs of such cultural unsuitability in housing are anxiety, stress, and a lack of sense of belonging ${ }^{90}-$ costs that must be avoided if the displaced are to negotiate a prosperous life in a new context. Although it is conceivable that with proper research and attentiveness that one could design an exceptionally sensitive dwelling for a specific culture, how does one do so without fixing that dwelling in actuality, thereby spoiling its potential use by another cultural group?

Amos Rapaport makes it clear in his reflections on his earliest work, House Form and Culture, that it may be possible to show that particular parts of the environment are supportive for specific components of culture given an understanding of the mechanisms that link them. ${ }^{91}$ These findings imply that it is not any one "best" solution that should be implemented when attempting to prepare a suitable housing strategy for the displaced, but to instead prepare a working mechanism or an infrastructure that may support a multitude of "best" solutions, as accorded by the various cultural practices it will be recruited to support.

Since the variety of cultures received in Ottawa due to government sponsored refugee programs is so great, and prevailing attitudes regarding privacy, security, and personal space will all differ greatly depending on which culture makes a unit its home at any given time, it would seem that refugee tenants should be able to control their personal environments to a high degree so that they can address their own culture specific needs. The four homes that currently exist adjacent to the Chapel are not flexible enough to meet the varying demands that would be placed on them, nor do they have the capacity to deal with the number of refugees who will be housed in the Culture Generator. Therefore, they will be removed to support a higher density of housing units, which will take the form of four

\footnotetext{
${ }^{90}$ Ibid. 69

${ }^{91}$ Rapaport, Amos. Culture and Bult Form - A Reconsideration 181
} 
residence towers. The rental units should themselves function as a negotiating mechanism between the individual tenants, the cultural systems they utilize, and the social services located within the generator, so that the needs of personal space, privacy, sociability, and networking can be reconciled on an individual basis as needs dictate. The housing market in Ottawa at present is too rigid to provide for such ongoing negotiations, but there are some historic examples that can be consulted, as they employ adaptive, liminal infrastructures that support the reflexive actions desired in the Culture

\section{Generator.}

The first of these precedents is the caravanserai, a building typology predominantly used along the trade routes of Asia, North Africa, and South-Eastern Europe, from the age of late antiquity ${ }^{92}$ until the advent of the railroad. Built to service merchants and their camel caravans along their journeys, the caravanserai was a large, permanent, stone building, with a large open rectilinear courtyard. The inside wall of this courtyard was composed largely of identical niches and bays, within which merchants could store their wares, animals, and themselves during temporary stays to rest and resupply. ${ }^{93}$ The modular layout of these bays allowed them to be reflexively occupied based on the size and needs of the caravan, and also held spaces for ceremonial baths and prayer, allowing those of various cultural backgrounds to adhere to their religious duties. Their modular construction practice proved to be so successful that the caravanserai eventually served a multiplicity of other functions such as, royal guesthouses, barracks, government offices, storehouses, and centers of worship. ${ }^{9495}$ Most importantly, these buildings were composed of a number of other liminal spaces, namely large entry

\footnotetext{
${ }^{92}$ O'Gorman, Kevın D and Prentice, Richard C (2008) Iranian bospitalty from caravanserai to bazaar to reporting symboltc experience 3

${ }^{93}$ Sims, Eleanor 1978 Trade and Travel Markets and Caravansara 101

${ }^{94}$ O'Gorman, Kevin D and Prentice, Rtchard C (2008) Iranaan hospitality from caravanserat to

bazaar to reporting symboluc experience 3

9s Yavuz, Ays1 Tukel 1997 The Concepts that Shape Anatohan Seljuq Caravansara 80-95
} 
portals that could serve alternatively as market, supply, and social areas as required, allowing for exchange and interaction between travelling merchants and the local population. Although often not a grand building, the caravanserai ultimately excelled in providing a utilitarian system which could be endlessly configured to provide the cultural and everyday necessities of its varying tenants, thereby functioning as a cultural exchange in its own time.
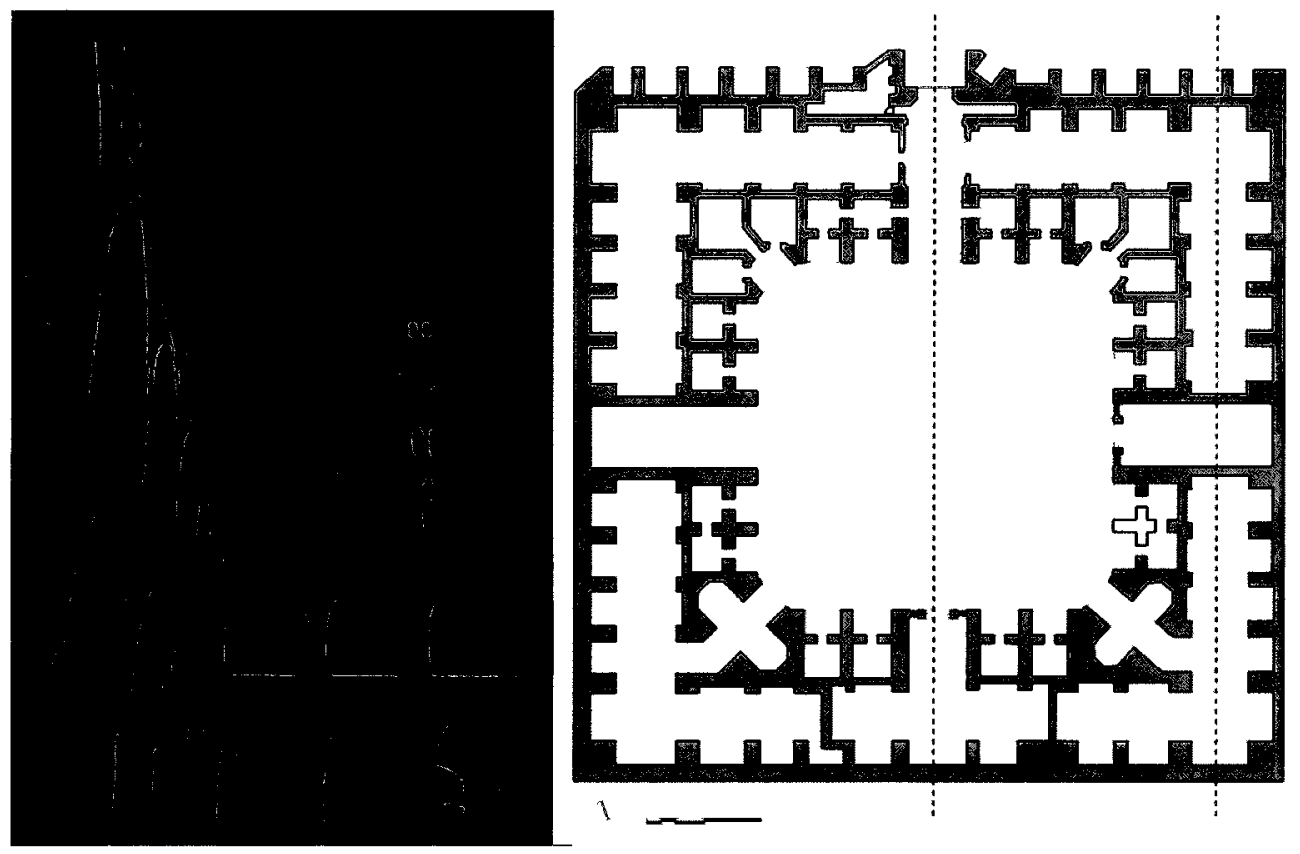

Fig. 21 (Left):

Caravanserai in Akko, Israel.

Fig. 22 (Right): Floor Plan, Safavid Caravanserai.

A more contemporary, and local example is the Strachan House, by Levitt Goodman Architects. Located in downtown Toronto, Canada, the Strachan House is a turn of the century warehouse reconstituted as housing for the most challenged of Toronto's homeless population. The primary goal of the Strachan House was to assist in establishing permanent residences for those in need, and thereby help normalize the lives of its tenants, many of whom suffer from mental health conditions or drug and/or alcohol addiction. When tasked with the problem of creating a safe haven for a transient population, the architects responsible activated the utilitarian space of the warehouse in much the same way as the caravanserais of old. By dividing the warehouse into 12 group "homes", and linking 
them through a central social space, called the "street", the architects supplied not just private spaces for individual persons, but public spaces as well - a system that has allowed for highly adaptable environments. For example, each home has a "kitchen", which serves as a liminal space that can be configured by the members of each home to mediate between the conditions of privacy and sociability. Through this utilization of indeterminacy and liminality, Levitt and Goodman embodied within the Strachan house a great potential for collaboration and negotiation, not just between its tenants, but also the social workers who are tasked with supporting them. Taking its cues from the permanent but adaptable caravanserai, and a modern counterpart, the Strachan House, the residences Culture Generator will also seek, in the words of Rapaport, to "establish generalized frameworks where the interplay of the constant and changeable aspects of man can find expression". ${ }^{96}$
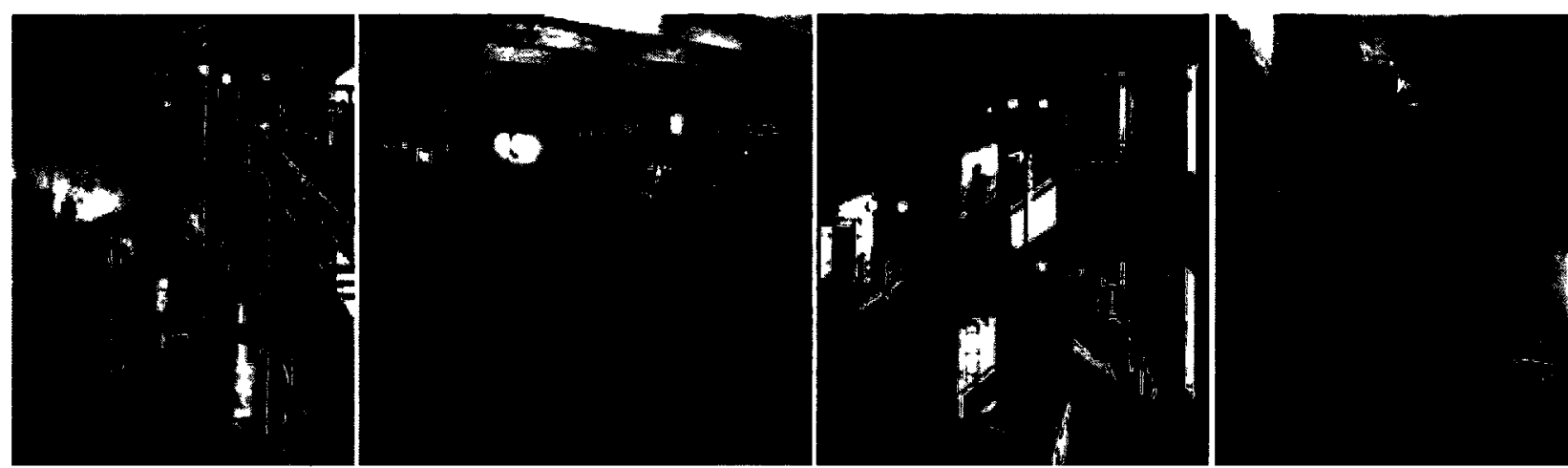

Fig. 23 - 26 (Left to Right) : Strachan House, "Street"; Strachan House, "Kitchen"; Strachan House, "Town Hall"; Strachan House, detail.

To maximize utility amongst its future tenants, the residence towers of the Culture Generator will at first be largely left un-built, with the infrastructure necessary for it to grow and orient itself in relation to the demands of its tenants constructed instead. This infrastructure will be comprised of a robust structural core that will not constrain the future growth of the units as demanded by refugee numbers and needs. The units themselves will be unitized and manufactured on site, so that the growth and

\footnotetext{
${ }^{96}$ Rapaport, Amos. House Form and Culture. p 135
} 
configuration of the residences can respond to cultural feedbacks more quickly than conventional construction methods. Resident units will be built identical to one another, but supplied with the means to alter its utility to cater to differing cultural attitudes such as privacy and personal property. They can be linked or severed from one another to respond to nuclear family sizes, household makeups, and to accommodate or eliminate the possibility of shared living spaces such as kitchens and dining rooms. Utility services will be run centrally through easily accessed bays, so that the potential of residence configurations will not be spoiled by the inability of plumbing and electricity to service them. Most importantly, circulation paths and un-programmed space will be put in place in the initial stages far beyond the needs of its initial tenant numbers, so that social nodes can be formed in response to needs as they appear during transition. Such un-programmed spaces can provide a great diversity in programming to increase the potential for interaction among its tenants, thereby catalyzing community and social support networks in the crucial first months after arrival. These nodes could take the form of (but are certainly not limited to) community or group kitchens, halls for ceremonies and celebrations, spaces for games and leisure, community green spaces, children's nursery spaces, and common lounge areas in residences, and residence units themselves. The base of each tower will also be a critical meeting point, as they form the interface between the dwelling units and the variety of services and skills offered through the Culture Generator. These are intended to function as the "kitchen" in the Strachan House, as an adaptable threshold that allows tenants to chose the level of engagement with the services on site, and the citizens of Ottawa. Again, indeterminacy is of paramount importance. As architects, it is often our impetus to design our way out of adverse circumstances that appear to us, instead of preparing preventative environments that are capable of 
reacting against such circumstances on their own. In the words of Cedric Price, "architecture is too long in gestation to be a serious problem solver". ${ }^{97}$

\subsection{Collaborative Information Co-Manufactory}

Keeping this notion of adaptability in mind, a relevant observation that surfaced in a Saskatoon study of refugee happiness levels serves to direct another important facet of the Culture Generator - the Collaborative Information Co-Manufactory. This study revealed that those women who were also able to establish a new network of contacts within the host culture reported the highest levels of happiness and satisfaction in their new lives, as these cross-cultural contacts helped to alleviate the frustration and confusion of operating in a new societal context. ${ }^{98}$ These close contacts typically develop through contact with the various NGO's, volunteer groups, and councilors who form the bulk of resettlement programming. These contacts however, are located in disparate places, are initially unfamiliar with a refugee's cultural norms, and are usually only contacted by the refugees after a problem has already occurred that requires solving, such as an erroneous social welfare claim, or a crisis in rental housing. The potential for collaboration and exchange in scenarios such as these are hindered either by the physical space, or cultural divide between refugees and support services. These initial meetings often digress into frustrating and vexing experiences, as the differing cultural norms and practices of both parties lead to frequent misunderstandings. In its research, the World Bank has stated that "the main difference between success and failure is the degree to which displaced people themselves are in involved in determining the quality and quantity of their services." ${ }^{99}$ If the bureaucracy of refugee

\footnotetext{
${ }^{97}$ Cedric Price, RIBA Journal, September, 1981. 67

${ }^{98}$ Fuchs, Linda. Factors Affecting Level of Happiness Among Southeast Astan Refugee Women in Saskatoon 8

${ }^{99}$ World Bank, World Development Report 2004
} 
resettlement, in all of its good intentions, is stifling the potential of refugees through its restrictive and unresponsive protocols, then what can be done through a built intervention to heighten the interaction between refugees and their support outlets in the host society?

Another project that sought to critically rethink an institutionalized problem in such a way was the Potteries Think-belt, by Cedric Price. Here, Price utilized the decaying industrial framework of the failing English ceramics industry and its supporting rail lines to build a higher education network across hundreds of square miles of English countryside. This radical re-interpretation of the university as an institution came as a response to the very same conditions and attitudes that frustrate refugee resettlement. In his reflection on Cedric Price's architectural propositions, A Philosophy of Enabling, Ryston Landau states that :

The bureaucratization of modern architecture as widely found in the British Public Sector was revealing an insensitivity to individual difference and showed no awareness of the possibilities of individual human potential. People had been reduced to standards, and standards had been further reduced to economics. The modern movement had espoused an enterprise which demanded a deterministic restrictiveness and left no room for individual movement. ${ }^{100}$

According to Price, the university as a place of learning had been discredited by its inability to react to technological and economic flux in an increasingly globalized world. Instead of distributing inflexible degrees based on requirements that were centuries old, universities should instead offer learning facilities at multiple stages of the users life as needs dictated.

To enable such constant reconfigurations, and to emancipate education from the elitist trappings of the university system, Price proposed building a school that literally moved. Utilizing abandoned rail-

\footnotetext{
${ }^{100}$ Landau, Ryston. A Philosopby of Enabling, in The Square Book. 11
} 
yards and underused highways, moving education spaces could be endlessly reconfigured on a network to support new curriculums. The pre-existing rail lines and roads would catalyze the movement of people and information, as well as the curriculum and lecture halls themselves, which Price saw as a mobile service that could be summoned on demand of its users. Through its indeterminacy, the Think Belt could avoid all classification as an institution, and immediately reconfigure itself to provide for the immediate demands of the changing economy and technologies. Most importantly, individual users could configure their education as they saw best in immediate reaction to market demands, thereby enabling them to prosper outside of a system otherwise incapable of reacting with sufficient speed to a changing society. Being unhampered by dogmas prevailing attitudes, "the university would become a launching pad for ideas and rather less of a Mecca of accepted truths". ${ }^{101}$

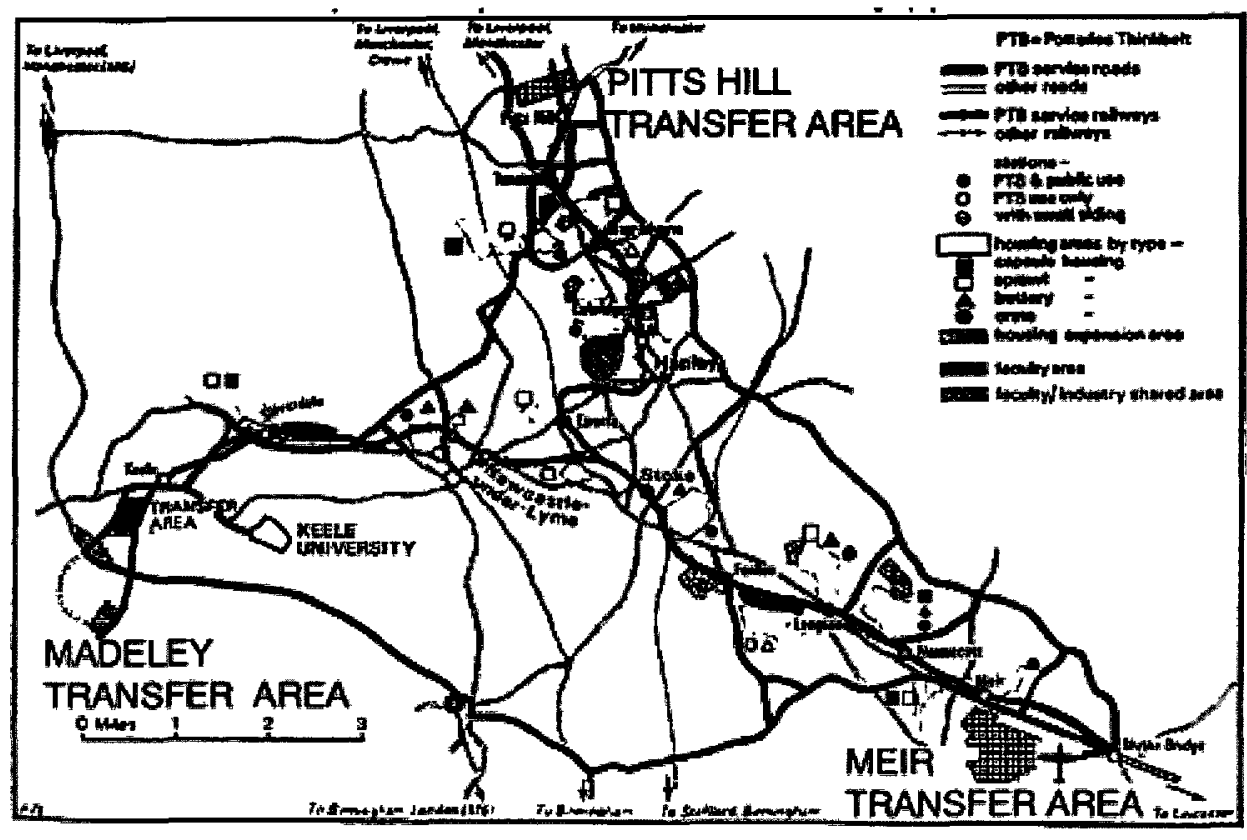

Fig. 27: Scheme Plan, Potteries Think-Belt. (Architect : Cedric Price. 1965)

${ }^{101}$ Price, Cedric. Actrvity and Change, Archigram 1962. In The Square Book. 26 

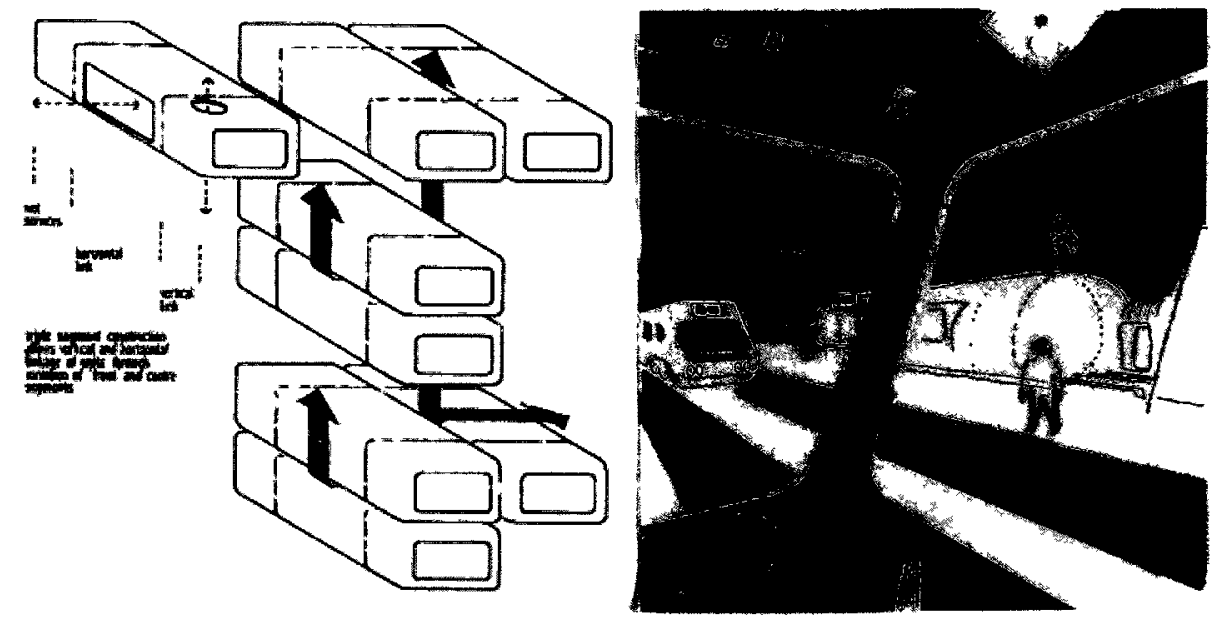

Fig. 28 (Left): Schematic axonometric studying functionality and possible configurations supported. Potteries Think-Belt. (Architect : Cedric Price. 1965)

Fig. $29 \quad$ (Right): Perspective - Mobile classrooms. Potteries Think-Belt. (Architect : Cedric Price. 1965)

Here, Price was primarily concerned with catalyzing innovation, by intensifying the exchange of ideas and knowledge - the same mechanisms through which the Culture Generator is conceived to catalyze the fabrication of new cultural identities. A similar intensification could be accomplished here, by providing temporary work spaces, or "nodes" to representatives of various social services within the Culture Generator itself, and full time "access points" for organizations and charities that deal predominantly with refugee settlement in Ottawa. By doing so, the Culture Generator could function much like a mall or stock exchange, except information and ideas would be the currency exchanged between participants, and not currency itself. By providing a more varied and less constrictive framework, refugees would be presented with the opportunity to access information and services in the order and combinations of their choosing, resulting in more focused and relevant assistance on a case by case basis. Increasing the availability, and variability of services could only serve to increase awareness, understanding - and most importantly - alter the balance of cultural exchange from one of "integration" on behalf of the refugees, to one more approximating equality amongst parties. Altering this balance would not only be of benefit to the displaced, but also to those organizations tasked with their well-being upon their arrival and transition phases, as it is their unavoidable lack of cultural 
understanding that frustrates both refugees, and their own efforts as social workers to alleviate the problems encountered by them.

Some organizations that could greatly benefit from the use of temporary work nodes supplied by the Culture Generator may include (but are not limited to) :

- Citizenship and Immigration Canada

- Service Canada

- Ontario Ministry of Health

- Ontario Ministry of Citizenship

- immigration lawyers

- professional translators

- United Way of Ottawa

- various culturally specific settlement and community organizations, such as the Somali Centre for Family Services, National Capital region Tamil Association, etc.

In contrast to those organizations that could temporarily occupy the infrastructures provided, there are a number of others that would be vital in the Culture Generator's success in helping its refugee clients/tenants to resettle in Ottawa are listed below, and would have representatives/resources on site at all time.

- the Ottawa Community Immigrant Services Organization

- Immigrant Women Services Ottawa

- City of Ottawa Immigration

- Ottawa Community Housing 
- City of Ottawa Library

- Adult Language Services

- employment services

- mental health professionals

This level and intensity of collaboration places many programmatic demands on the Culture Generator - office spaces, boardrooms, classrooms, private screening/therapy rooms, and computer and internet access stations are all necessary for the Collaborative Information Co-Manufactory to be successful.

To prevent one single orientation of these programs from inhibiting the potential of future configurations, the Information Co-Manufactory will largely be comprised of a unitized structural grid, an infrastructure, that spans the breadth of the site. Much like the residence units, usable floor space will be maximized through a minimal use of load bearing structures, with this usable floor space segregated in an optional fashion using devices such as screens, and moving partitions. The structure put in place will be well beyond the needs of the double height space that will be initially provided, in the contingency that the Culture Generator will eventually demand more room for programming. This new infrastructure will link the two buildings that remain on the site - the small chapel at the corner of Main Street and Echo Drive, and the office building at the corner of Main Street and Greenfield.

At present, most English as a Second Language Courses (referred to as ESL from here on) paid for by the government upon resettlement usually last for 20 weeks of full time study, even though some in the field of resettlement find that a full year of study is insufficient for a refugee wholly unfamiliar with 
the English language to be comfortable using it on a day to day basis. ${ }^{102}$ Another common problem is that basic literacy classes do not include any job specific language training that can be easily utilized in the workplace. Such job specific language courses are available to sponsored refugees, but only after a suitable amount of English language proficiency has been attained in other courses. ${ }^{103}$ The resulting time for a displaced person in Canada to become reasonably language proficient for any given workplace would be well over a year if they had little initial knowledge of the English language on their arrival. With studies showing that the first 3 years of a refugee's resettlement will often determine their continued success, ${ }^{104}$ it would seem that spending nearly half of that time acquiring passing language skills to be an unsatisfactory situation

In a Case Study of his own resettlement program in Upstate New York, John L. Van Esterick makes mention of the frustration his clients experienced upon their arrival to local high schools to begin their ESL training. Walking through the halls to their English classrooms, refugees would frequently encounter automobile repair shops, aesthetics clinics, home economics classrooms, or computer classes, and then inquire about or demand access to them - demands Van Esterick had neither the funds or permission to respond to. ${ }^{105}$ According to governing bodies and regulations, these classes fell outside the scope of the training that should be provided to refugees, even though they were seen by the refugees themselves as the quickest path to gainful employment, financial security, and actualization of their stated goals as newly arrived Americans. ${ }^{106}$ Since economic data and refugee interviews have supported a view that such job specific skills are indeed vital, (if not more vital than

\footnotetext{
${ }^{102}$ Van Esterik, Communicative Claims in a Refugee Program Case Study of an Antbropologist as a Service Provider 187

${ }^{103}$ The following address is a course list of profession specific ESL courses offered in Ottawa, and their correlating English proficiency levels : http.//www onlinetools ontarioimmıration.ca/esl/wizard/step5 aspx'culture=en\&external=f\&l=en\&c=54\&pt=11\&d=1\&t=1

${ }^{104}$ Stein, B N Occupational Adjustment of Refugees The Vietnamese in the Unted States International Migration Review 13(1): 24-45

${ }^{105}$ Van Esterik, Communicative Claims in a Refugee Program Case Study of an Anthropologist as a Service Provider 187

${ }^{106}$ Ibid 187
} 
fundamental English literacy), a primary goal of the Culture Generator will be creating a hybrid practice of job specific language instruction while accumulating work hours to familiarize newcomers with the Canadian workplace. Although many refugees arrive with relevant experiences from their country of origin, their potentiality is often stifled by prevailing attitudes and the bureaucracy of state run immigration programs.

In contrast to the accepted norms of resettlement employment and language programming, The culture generator offers an emancipatory $\operatorname{plan}^{107}$ to the problems of language education and gathering workplace experience, with the hopes of shortening the time necessary to gain permanent employment while generating small amounts of personal income.

The term emancipatory ${ }^{108}$ has been borrowed here from Korman and Lebas' reflection on the works and writings of Henri Lefebvre and Constant Niewenhuys, two leading figures in the Situationist movement centered in Paris and Holland in the 1950's. In reaction to what they deemed an isolated, repetitive, and ultimately deterministic daily life dictated by Capitalist economic systems (the same systems that ultimately dictate the path and pace of a refugee's settlement), the Situationists posited a new life of "situations" to restore the poetic and ludic aspects of the daily experience, thereby increasing the quality of life of individuals. ${ }^{109}$ These "situations" were made possible in an architectural sense through "emancipatory planning" - by the linking of spatially separated neighborhoods and heightening interaction and exchange between citizens, thereby returning daily experience to a more authentic human condition. Emancipatory planning, therefore, constituted a duel project of recovery

${ }^{107}$ Kofman, Eleonore and Lebas, Elizabeth Recovery and Reappropration in Lefebvre and Constant 87

${ }^{108}$ Henrı Lefebvre on the Situationıst International Interview conducted and translated 1983 by Kristın Ross Printed in October 79, Winter 1997 - http //www notbored org/lefebvre-interview html

${ }^{109}$ Kofman, Eleonore and Lebas, Elizabeth Recovery and Reappropration in Lefebvre and Constant 86 
and re-appropriation. It resisted separation between activities, people and ambiences, and created places for meeting and sociability. Constant's work specifically emphasized nomadism, flexibility, and the choice of environments. ${ }^{110}$ Similarly, the Culture Generator will offer multiple and simultaneous education and employment opportunities, providing refugees the choice of the environment that best suits their needs, or the option to fabricate one of their own within the infrastructure provided.

For instance, "sewing" is one job specific ESL program offered in the Ottawa area to the refugee population, and one of the few that does not require previous English language experience to enroll. ${ }^{111}$ Instead of hosting such a class in a local high school classroom, merely learning the language to communicate in a tailor/seamstress' environment, the language class could instead be a tailor's shop where alterations and clothes could be made, with the necessary communications being learned concurrently. By providing an alteration or a dry cleaning service to the local community, the class itself could be revenue generating, thereby empowering those enrolled as they gain valuable hands on experience dealing with customers. While learning and gathering Canadian work experience, the residents of the Culture Generator should be able to exploit the commercial street frontage available on Main Street and Greenfield Avenue whenever they see an opportunity to do so.

As another example, refugees from more agrarian economies could have the potential to grow produce on site in an urban garden or greenhouse to reduce the cost of food and increase personal health, while helping to mitigate the effects of cultural disconnection. Produce could even be sold to the citizens of Ottawa from a temporary retail space or market on site. The constant reconfiguration of the services

\footnotetext{
${ }^{110}$ Ibid 87

${ }^{111}$ The following address is a course list of profession specific ESL courses offered in Ottawa, and their correlating English proficiency levels : http://www.onlinetools.ontarioimmigration.ca/esl/wizard/step5.aspx?culture $=$ en\&external=f\&l=en\&c=54\&pt=11\&d=1\&t=1
} 
and the living units within the Culture Generator could provide hands on trade or construction experience for resident refugees. Tenants could not only specify the alterations to their living environment, but also participate and gain valuable work experience from them. Could the communal kitchens at the base of a residence tower not be licensed and inspected to serve as a restaurant, so that refugees could market their "authentic heritage" in the form of dishes for consumption by the public? Could the workstations used for computer literacy training and job searches not double as an internet cafe and coffee shop during the day to provide service jobs for some of the resident refugees?

Again, the goal is not to specify all of the opportunities that will exist in the Culture Generator, but to provide a foundation or system that constantly causes its users to question what opportunities could be present on an ongoing basis as the needs of refugees and society as a whole change.

\subsection{Cultural Interpretation Mall}

The description of the Culture Generator comes to a close where it started, with the aging chapel that used to sit incongruously at the corner of Main Street and Echo Drive. No longer sagging and swaying, but braced by the infrastructure that serves to heighten its potential, it has been repurposed as a Cultural Interpretation Mall. Now carefully augmented, the chapel's potential has been heightened to allow for the variety of ways in which the tenants of the Culture Generator can congregate, and market their traditions to the citizens of Ottawa.

The chapel will still function largely as a ceremonial building, but it will now be capable of serving many beliefs at once. Supported by flexible spaces that can be utilized for storage, management, and even construction, it will have the potential to grow with its congregations, and to support the visual displays of marketed heritage that Kirschenblatt-Gimblett spoke of, such as dances, feasts, festivals, 
and parades. The chapel is ideally situated on a well trafficked corner, adjacent to a parkway and Ottawa's primary attraction - the Rideau Canal - making it a highly visible and accessible. Such a desirable position should be taken advantage of by its residents at every opportunity, to call out and be noticed, and hopefully, understood. As both Niedermuller and Kirschenblatt-Gimblett have shown, the ability to display one's heritage publicly - even if that heritage will in large part be a contrivance - is often a necessary and vital step in the recognition, and eventual acceptance of a displaced or minority group in a plural society.

The decision to both physically link the chapel the Culture Generator, and metaphorically with the fabric of Ottawa serves a dual purpose here. In a strictly utilitarian sense, such a move was necessary to justify the continued presence of the chapel in light of rampant development, and also to begin administering to the ailments of the government sponsored refugee program. In a greater sense, this approach to adaptive reuse serves as a built criticism of both heritage conservation, and the existence of a cultural heritage in general.

As a religious building, the chapel could easily be targeted for conventional heritage conservation practice, and muzeumized to protect its material qualities. Instead, the chapel has been purposefully woven in to the continuous, living fabric that is the Culture Generator. Through this union with the other "historic" building on site - the mundane office building dating from the 1950's - architecture has been reinforced as a utilitarian cultural system, and not a symbolic product of culture. Materially linked to its evolving context, and thereby evolving itself, no attempt can be made to fix the chapel's utility and meaning, thereby robbing it of its embodied potential. Instead, it is read merely as another trace, which, when experienced amongst its new surroundings, tells an entirely different narrative - 
that of a tool used throughout its history, and now its future - to stimulate growth and manufacture new traditions for the displaced. 


\section{Closing}

It is likely that any person who may read this paper will have come across Henry Ford's quote, that "history is bunk". Taken out of context, these words serve as little more than an empty cliché. Read in its entirety, however, his words echo those of Eliot that opened this paper. "History is more or less bunk. It's tradition. We don't want tradition. We want to live in the present, and the only history that is worth a tinker's damn is the history that we make today."112

The overwhelming majority of refugees come to Canada optimistic, or even euphoric after fleeing the difficulties that forced them from their homelands. ${ }^{113}$ Each of them are eager to turn aside the past, look forward, and create a new prosperous existence in light of all that they have had to leave behind. This inherent desire to prosper is frustrated not by the capabilities of refugees themselves, but by the inflexible institution of government refugee sponsorship. Constrained by legislation and institutionally isolated, refugees are often marginalized from the political, economic, and social spheres of daily life. Robbed of the power to define and represent themselves ${ }^{114}$, refugees are forced to retreat to the only public sphere left to them - that of cultural difference, through displays "tradition". 115

This response to difficult social circumstances is how culture, taken as traditional performance or symbolic locality, can cause both social and political withdrawal into ethno-cultural identity - a process we know as ethno-cultural fundamentalism. ${ }^{116}$ Although this process of mobilizing ethno-cultural heritage may be a logical response to the social environment in which refugees find themselves, the resulting exclusion of those who do not belong to the "authentic" tradition performed only serves to

\footnotetext{
${ }^{112}$ Henry Ford, Interview in Chrcago Tribune, May 25th, 1916

${ }^{113}$ Crossley, B Tusha Fundamentals of Government Sponsored Refugee Settlement 159

${ }^{114}$ Brydon, Diana Why Communtty Matters 246

${ }^{113}$ Smith, in Niedermuller

${ }^{116}$ Niedermuller, Ethnictiy, Nationality, and the Myth of Cultural Herntage A European View 249
} 
deepen feelings of isolation and exclusion among the displaced. ${ }^{117}$ These actions do not seem to be made by choice, but as an ingrained reaction to a disadvantaged position within an unfamiliar society.

If Canada aspires to be a truly pluralist society of equal opportunity, prosperity, and inclusion for all of its citizens, then the potential of its sponsored refugees must not be inhibited by the cumbersome bureaucracy that too often fixes their paths. As architects, we are often called on to contribute to the larger system within which refugees must negotiate a new existence, and are therefore at least partially accountable for their success. With this responsibility in mind, care must be taken to ensure that our decisions as architects do not contribute to the stagnation of those who arrive from different cultures, but instead enables them to assemble new identities and skills that may allow them to prosper.

We can do so by straying purposefully from our predisposition to dictate the shape and function of the built environment, and instead let it shape itself, as a working system of culture within society. This pertains not only to that which we build now and may chose to build in the future, but also to our actions in regard to what already exists as built form. As the composition, complexity, and beliefs of our society shift in the globalized world, we as "Canadians" can also be inclined to the same backward looking action as our marginalized newcomers - to salvage outmoded cultural systems and assert them as authentic tradition. To the architect or planner, this act of fabrication comes in the form of heritage designation, which all too often fixes the utility and identity of our cities and the buildings within them, and removes them from the ongoing dialogues within society. As Price said, any built form so consciously fixed can only hinder the society that hopes to utilize it, through its inherent obsolescence. $^{118}$

\footnotetext{
${ }^{117}$ Gwynne-Vaughan, Stephen. A General Model of Refugee Immegration Home, Displacement, and Host-Related Factors in the Resettlement of Somali Refugees in Ottazva. 185

${ }^{118}$ Price, Cedric. The Square Book 35
} 
Just as this project has critically challenged the ideas of heritage and identity within the context of resettlement to heighten the potential of Ottawa's refugee population, it has done likewise for the ideas of heritage and identity with respect to our cities. It would seem that the potential of both can periodically fall victim to our tendency to attempt to clearly define our culture, instead of letting our culture continually re-define itself in relation to shifting political, social, and global surroundings, as it always has.

As Eliot said "We are always in danger, in clinging to an old tradition, or attempting to re-establish an old one, of confusing the vital, and the unessential, the real, and the sentimental. The second danger is to aim to return to some previous condition which we imagine as having been capable of preservation in perpetuity, instead of aiming to stimulate the life which produced that condition in its time." 119

${ }^{119}$ Elıot, T S After Strange Gods 18-19 


\section{Site Documentation / Analysis}

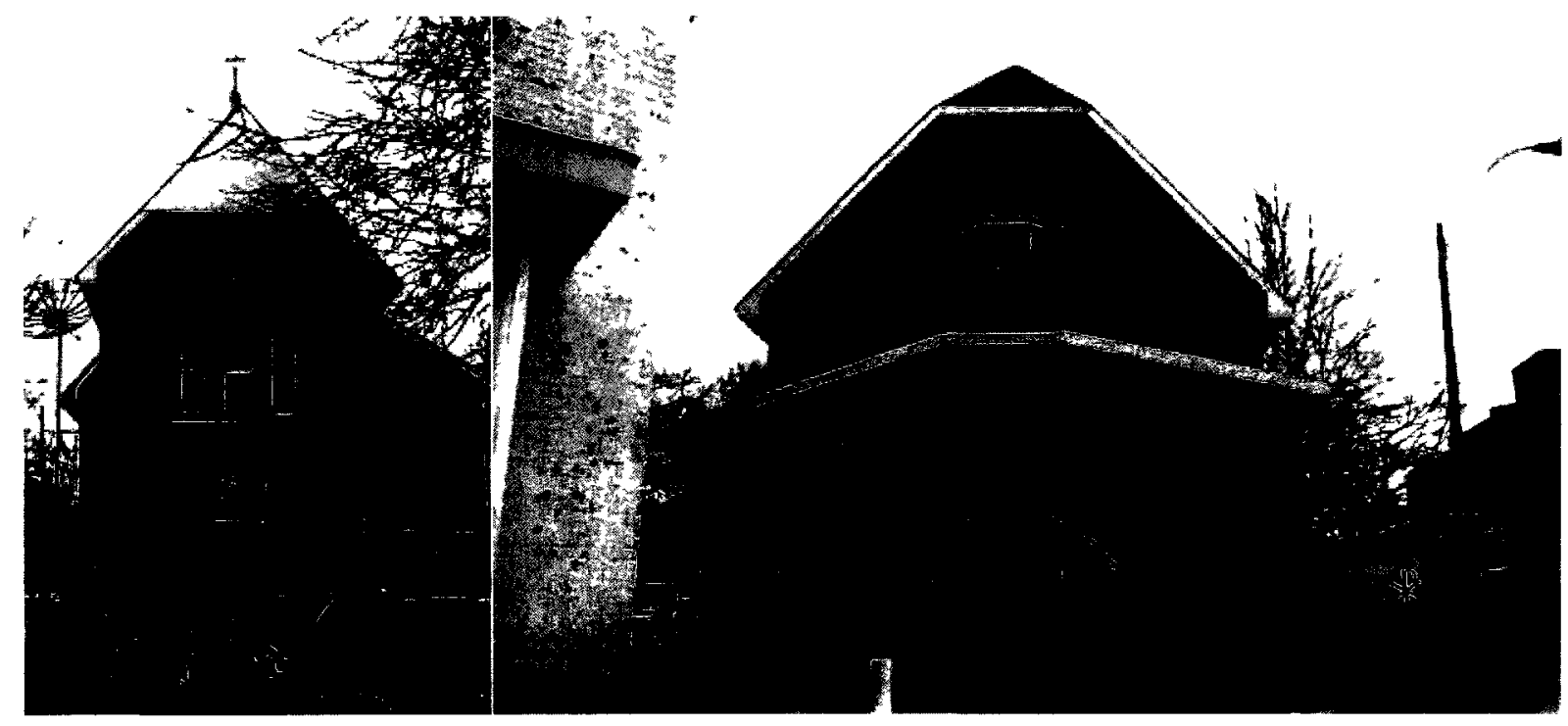

I.a - Chapel facing North

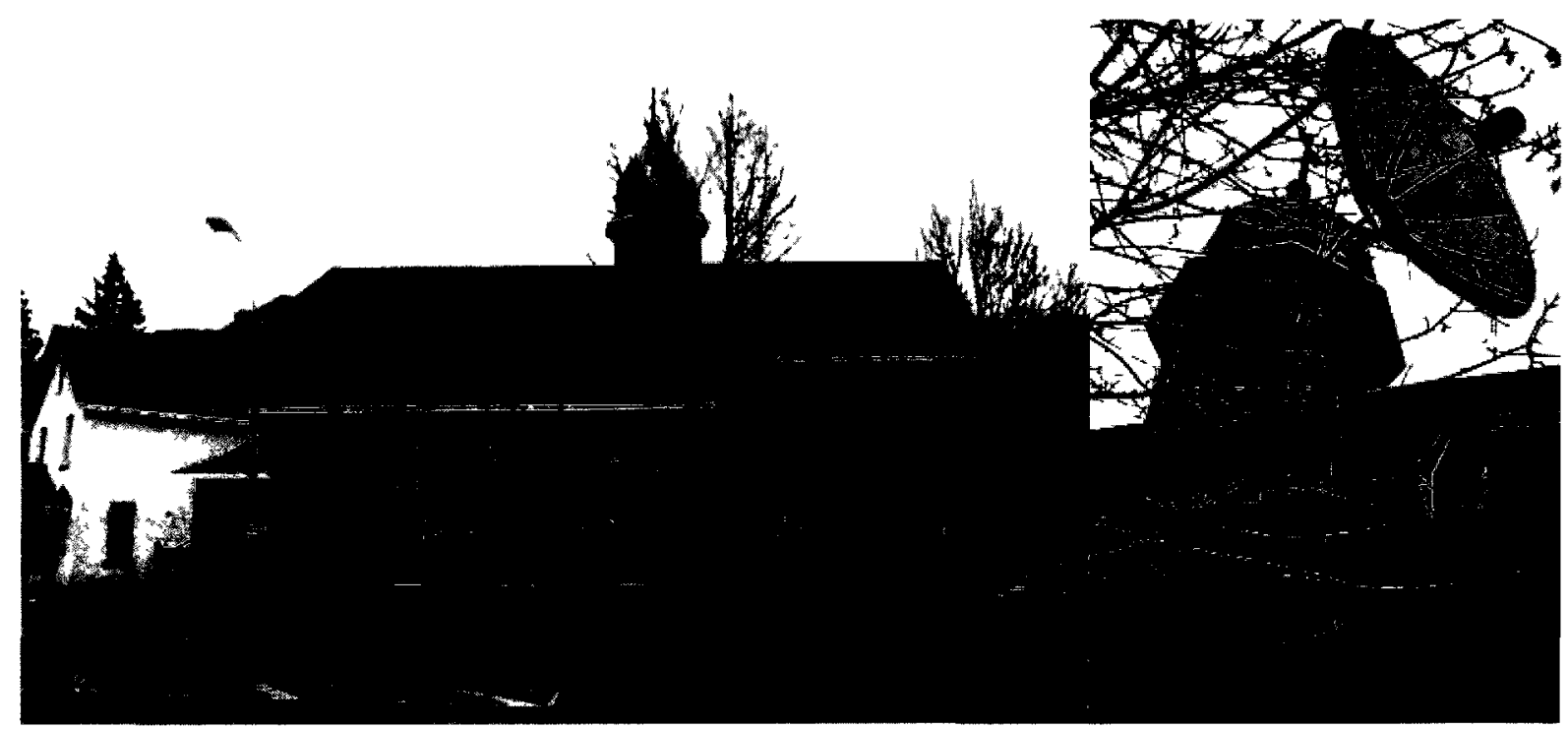

I.c - Chapel facing East

I.d - Chapel cupola and satellite dish 


\section{Site Documentation / Analysis}
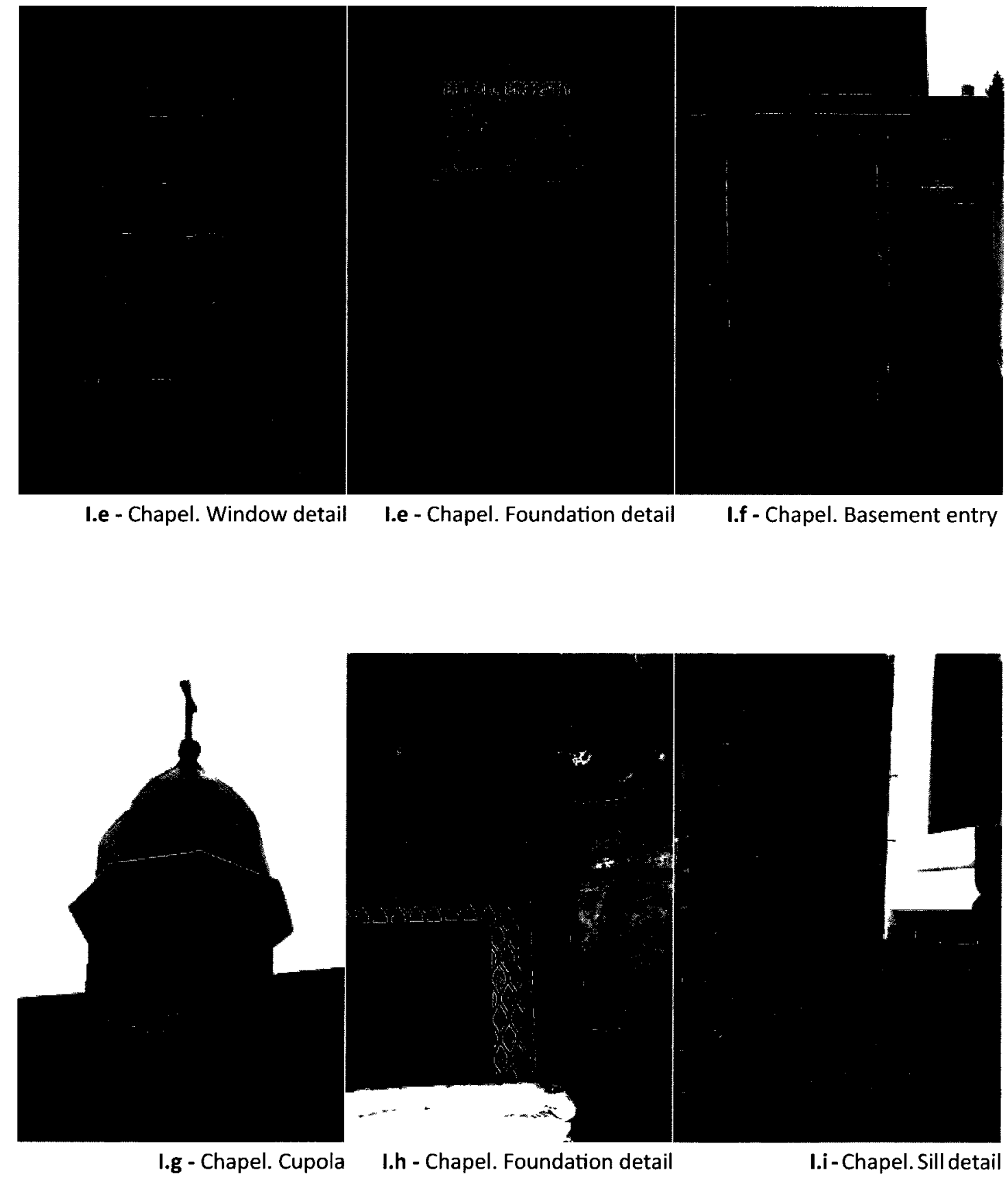


\section{Site Documentation / Analysis}
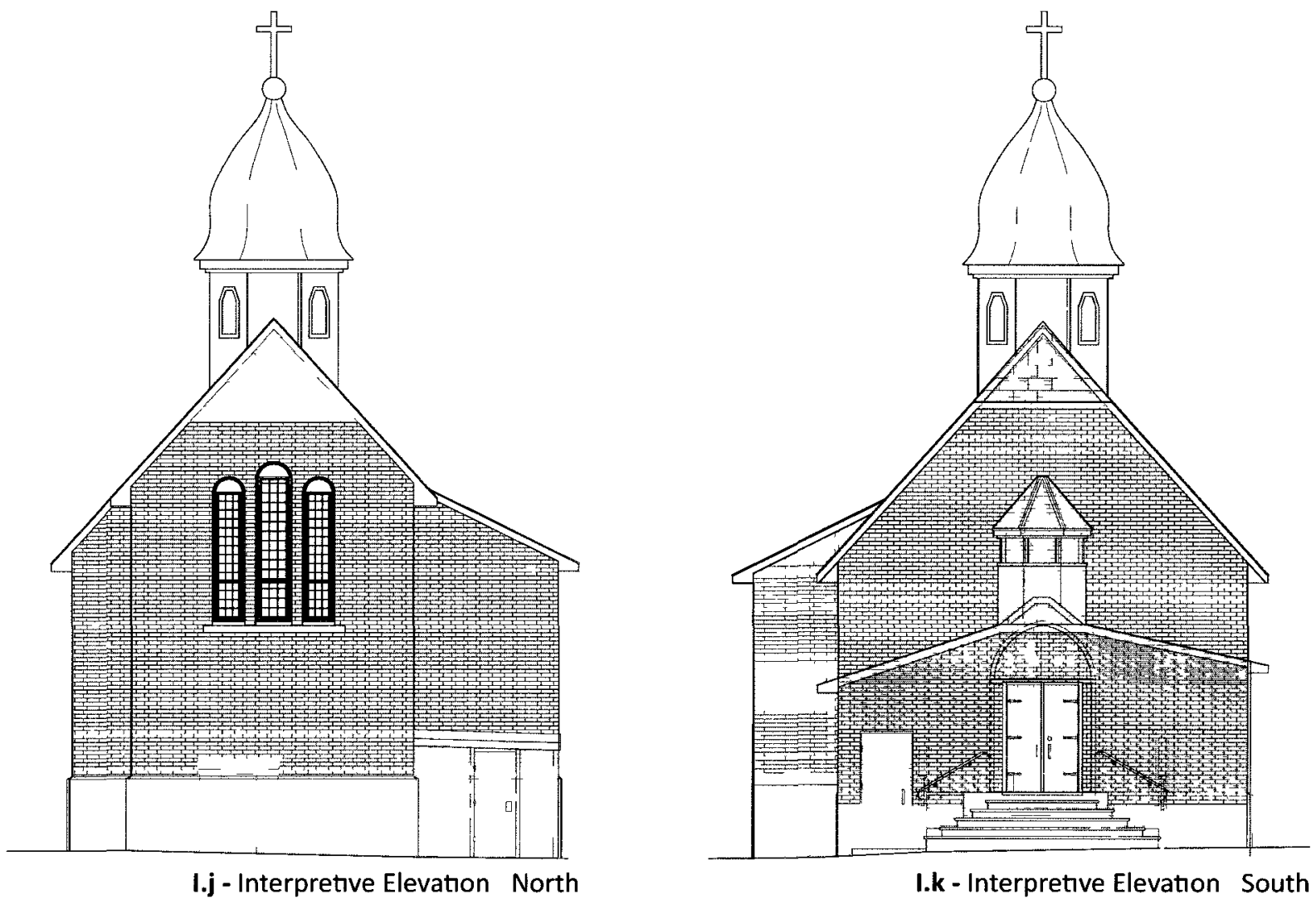


\section{Site Documentation / Analysis}

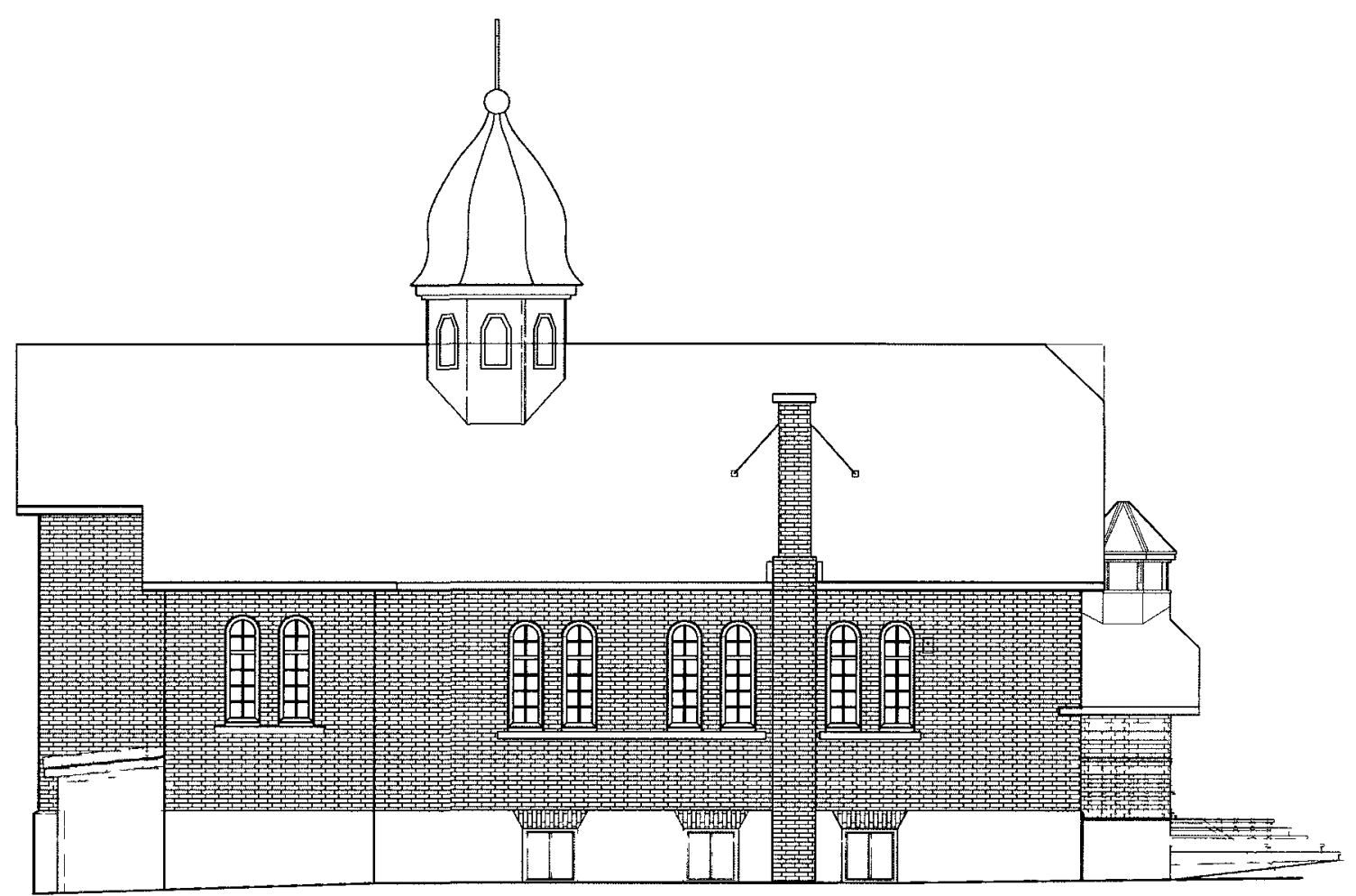

I.I - Interpretive Elevation : West

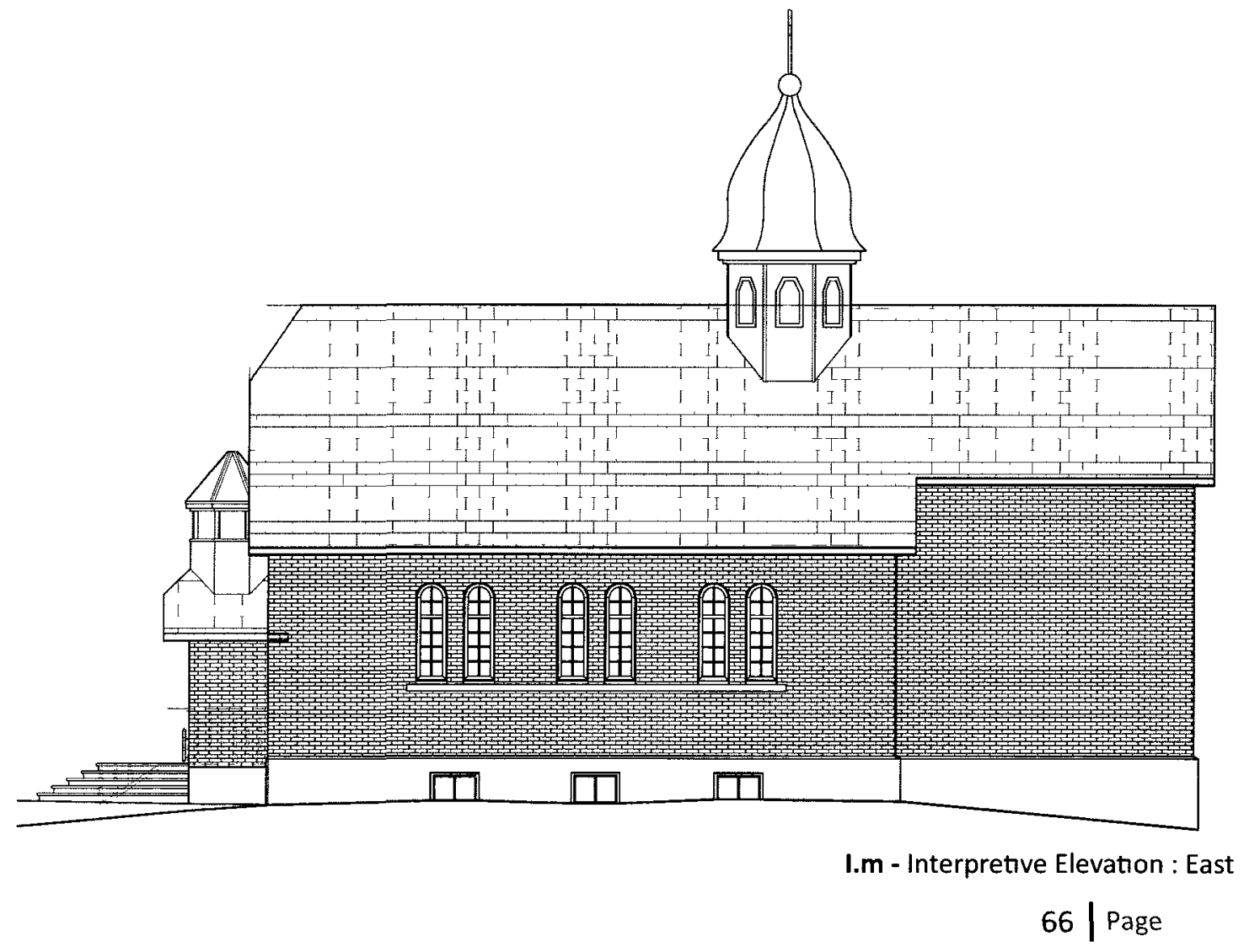




\section{Site Documentation / Analysis}

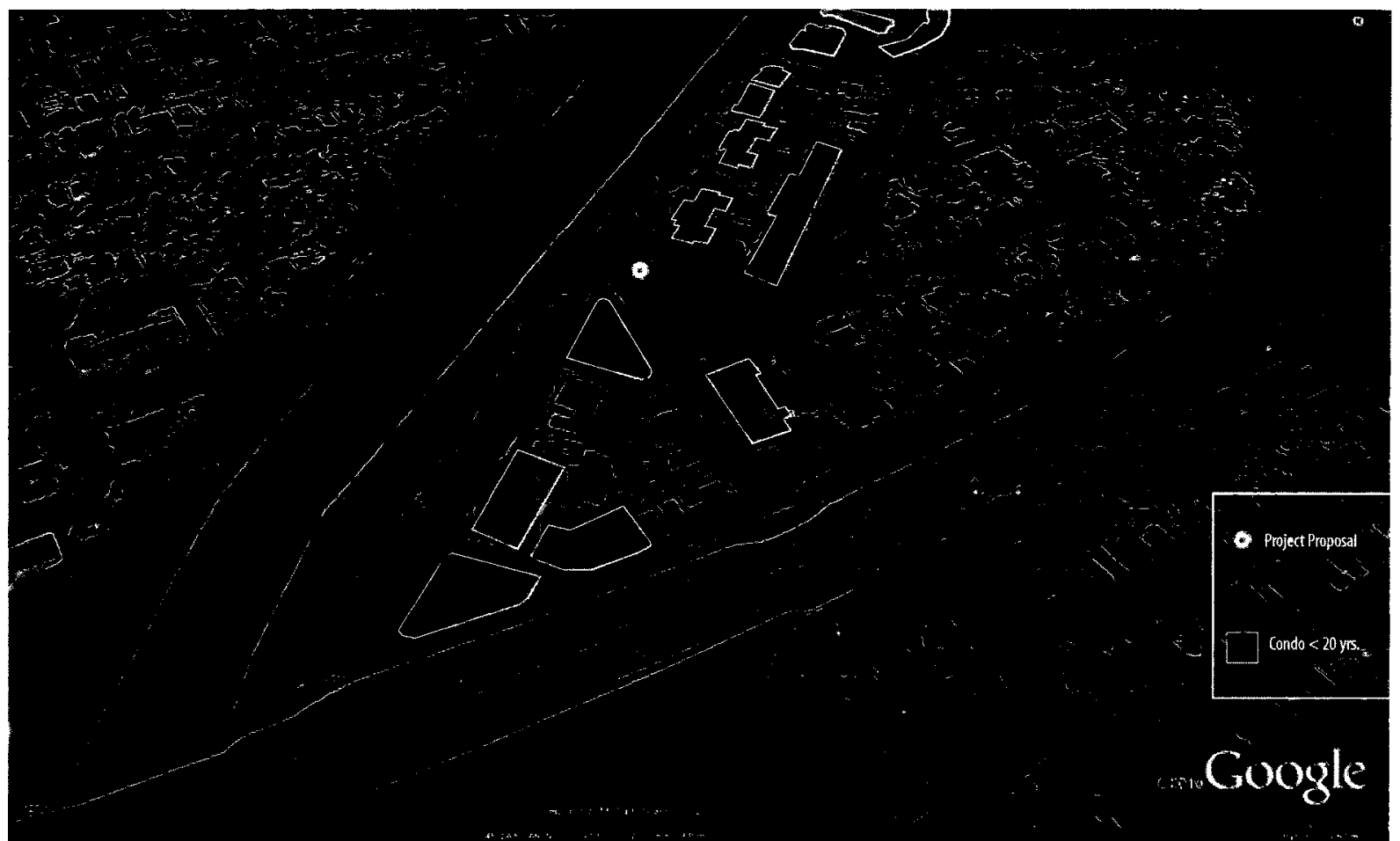

I.n - Context Map : Encroaching Development

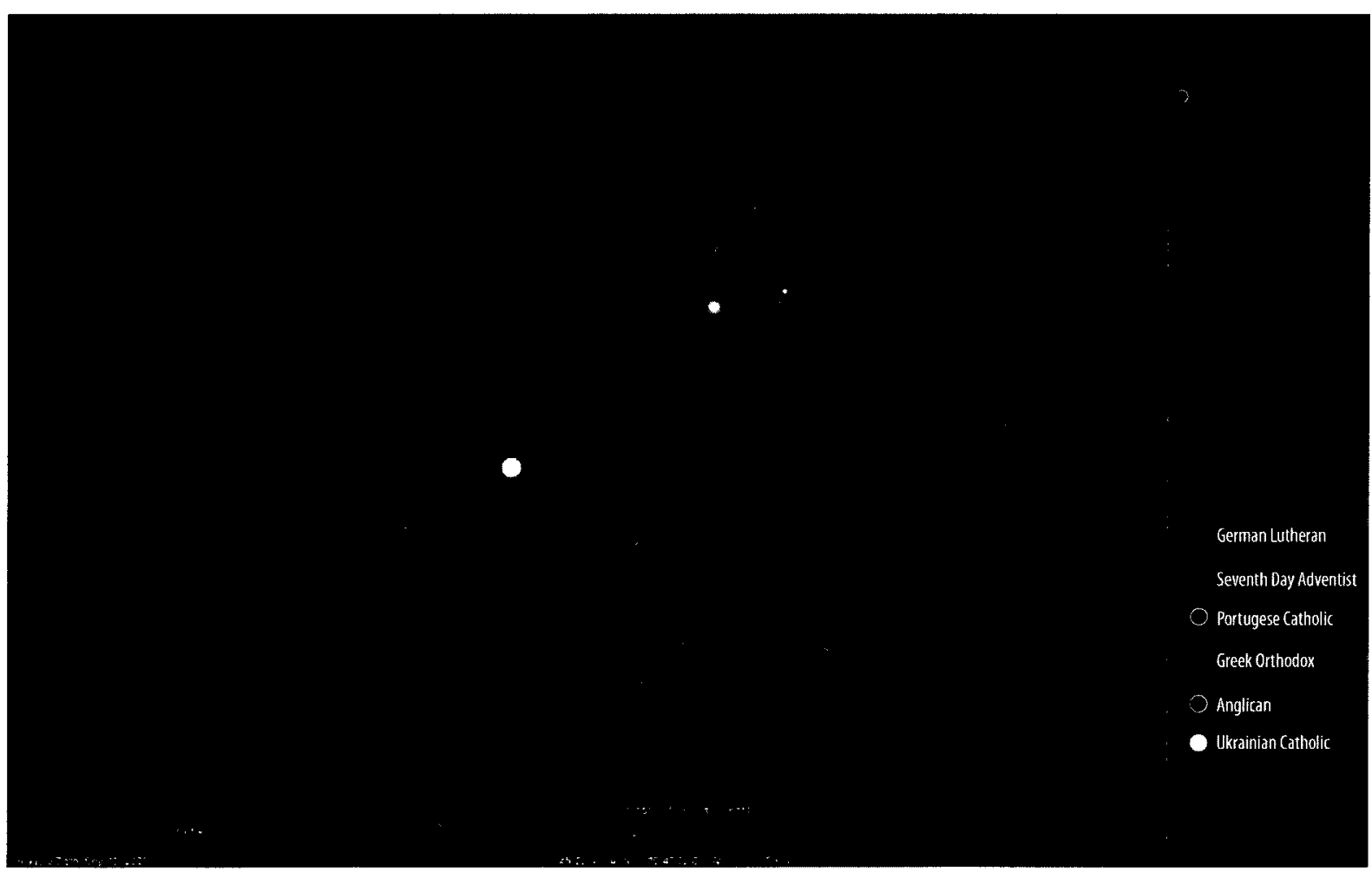

I.o - 115 Echo Drive : Growth and Distribution of Congregations 


\section{Site Documentation / Analysis}

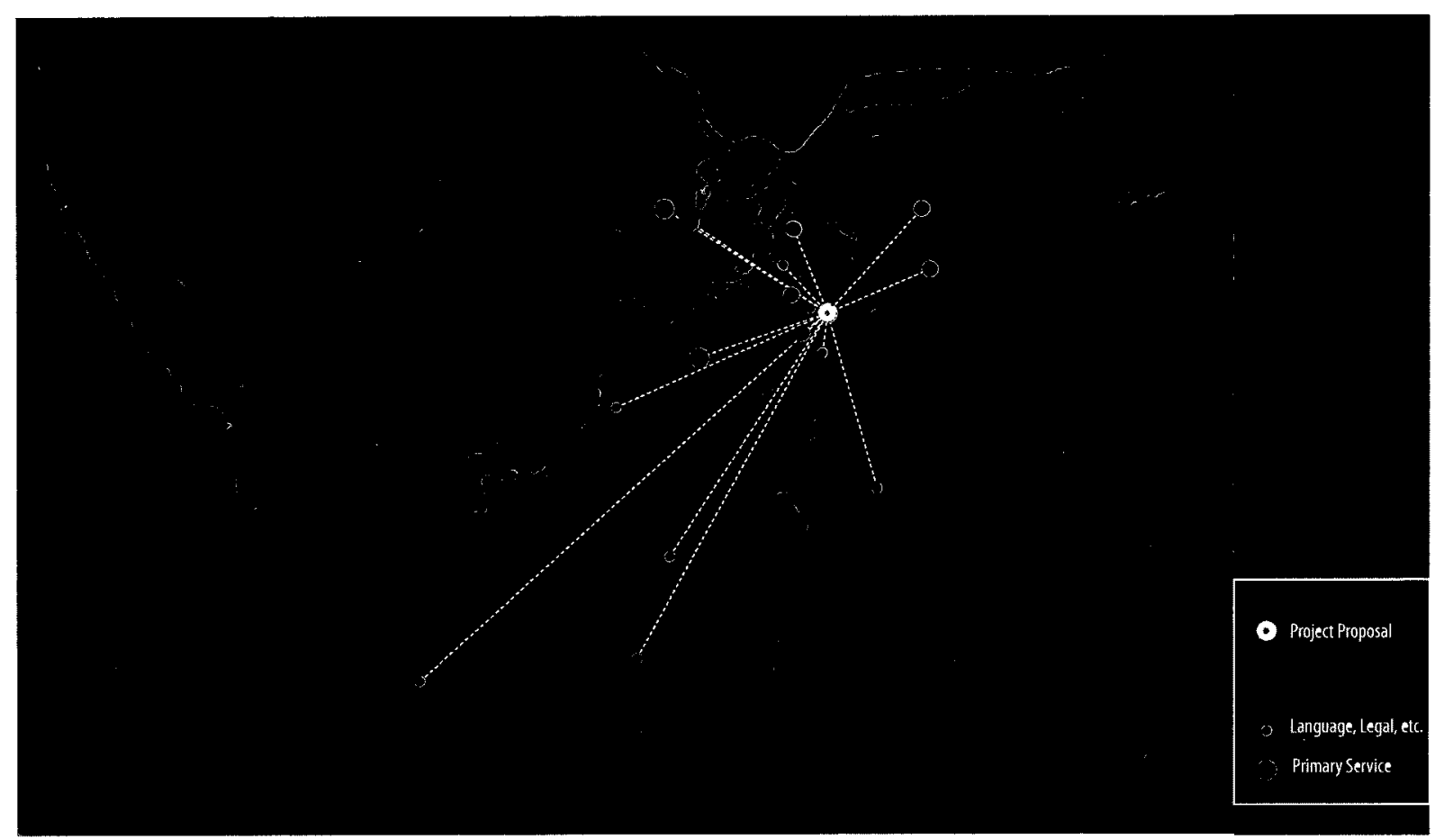

I.p - Context Map :Immigration Services

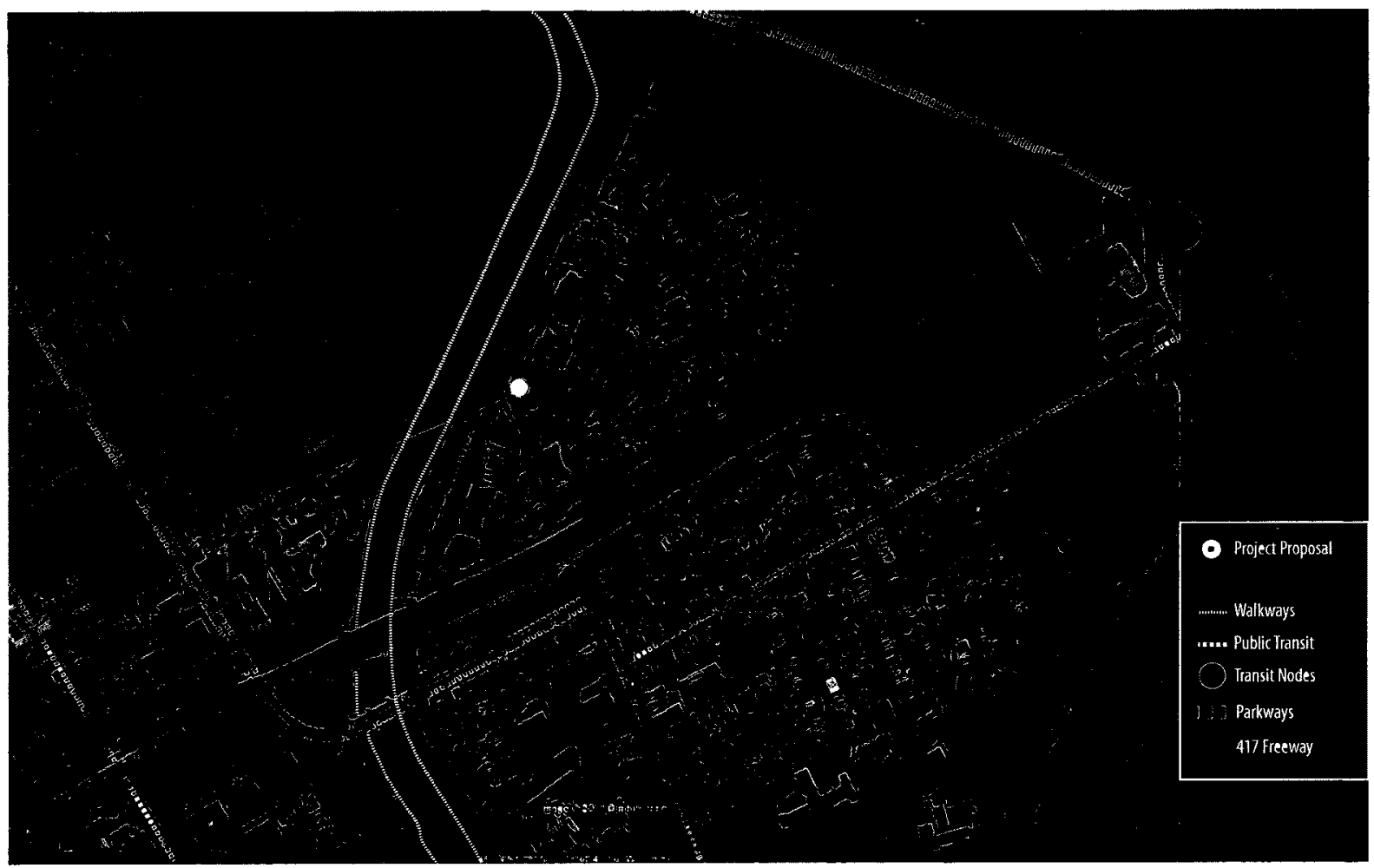

I.q - Context Map : Connectivity

$68 \mid$ Page 


\section{Site Documentation / Analysis}

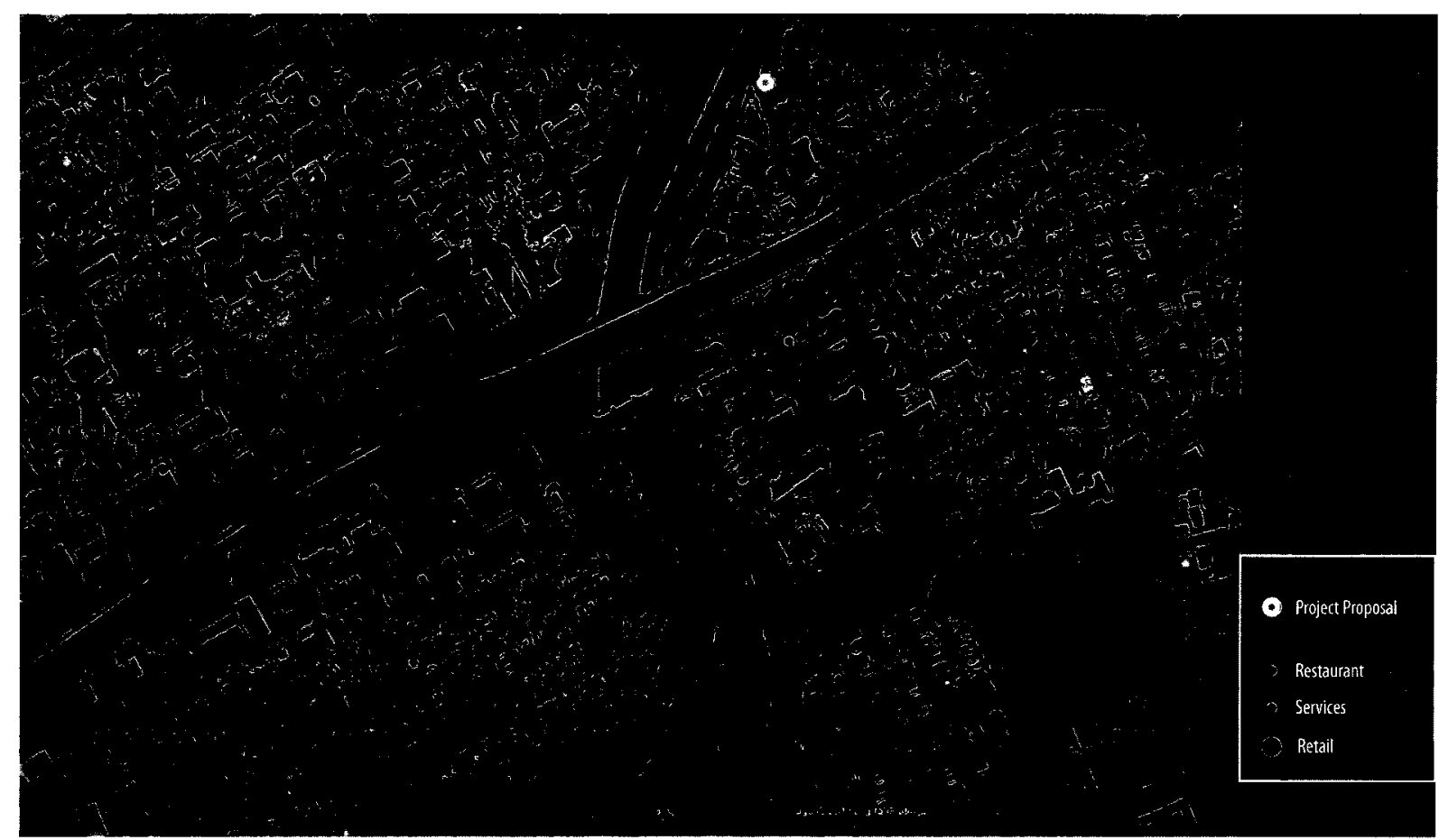

I.r - Context Map : Commerce

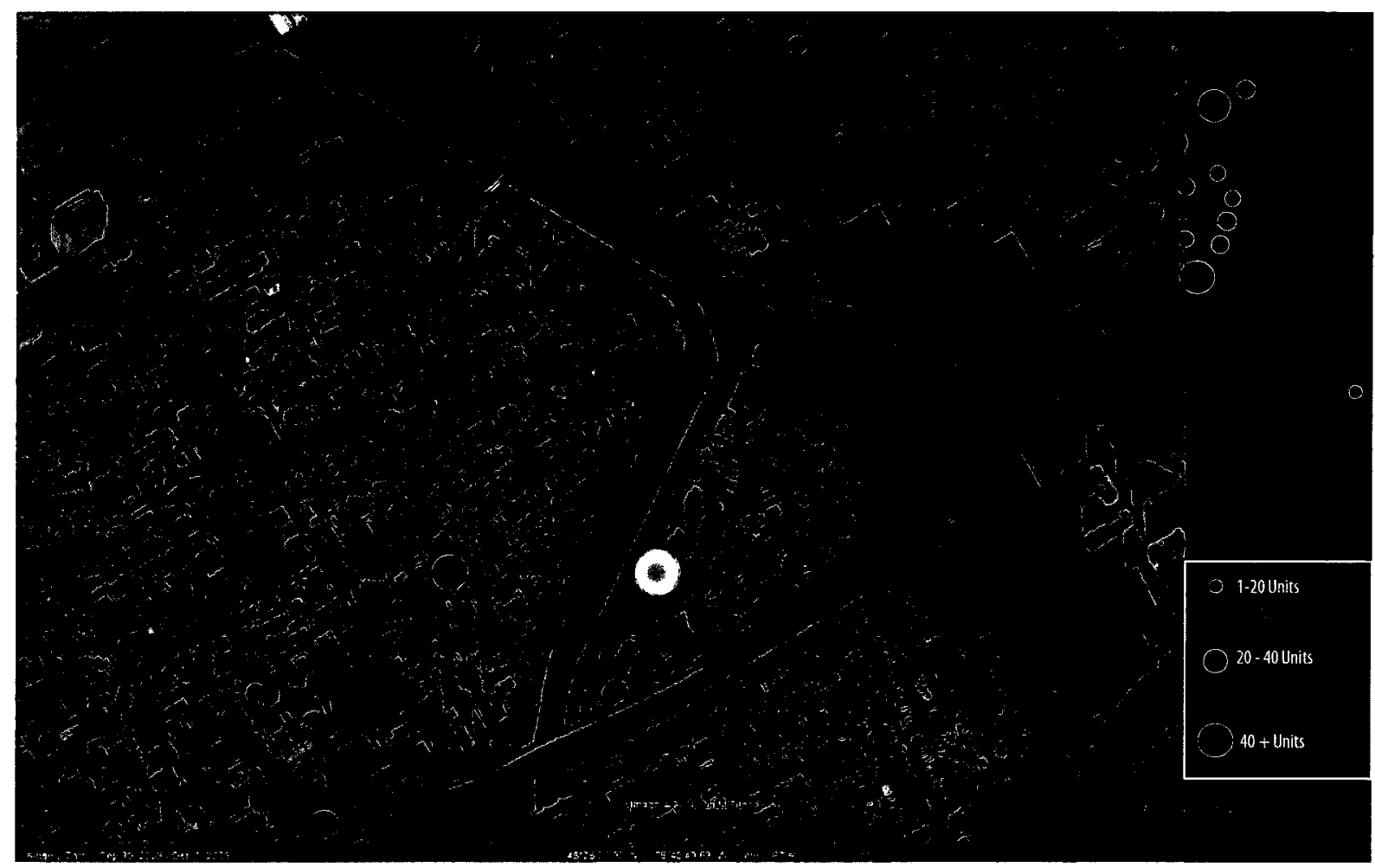

I.s - Context Map: Existing Social Housing

69 | Page 


\section{Development / Processes}
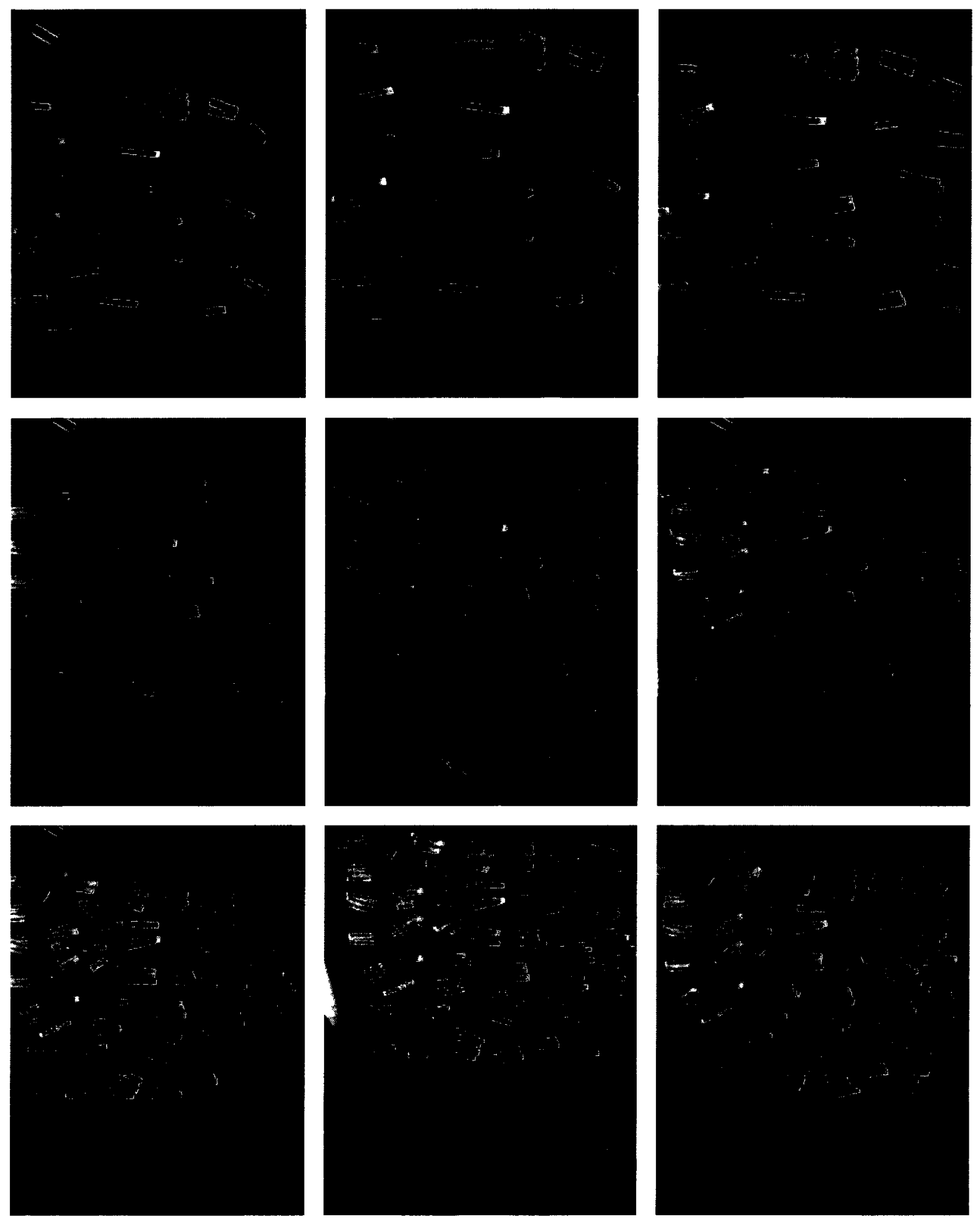

II.a - Generating Programs

70 | Page 
II. Development / Processes

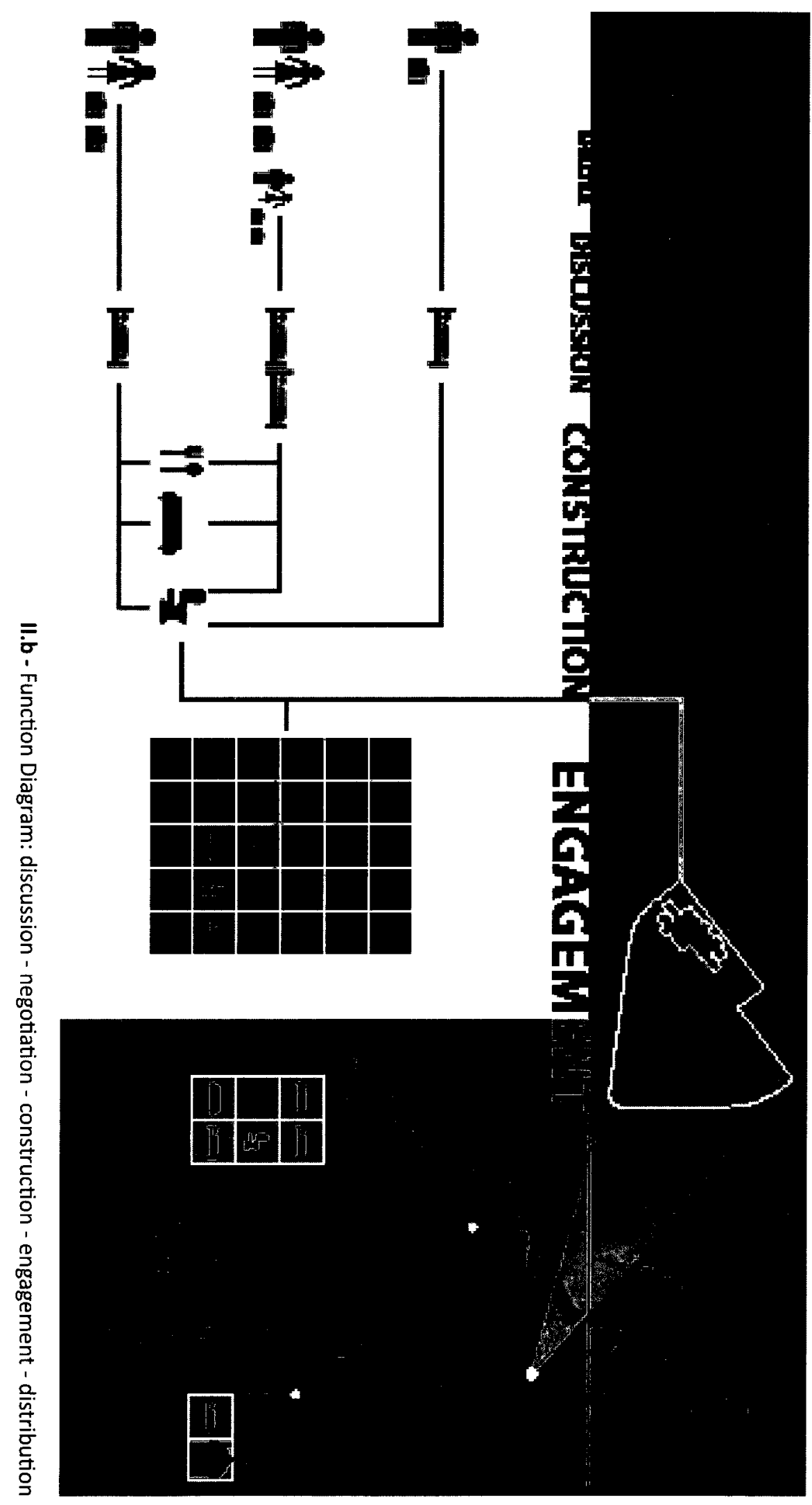




\section{Initial Proposals}

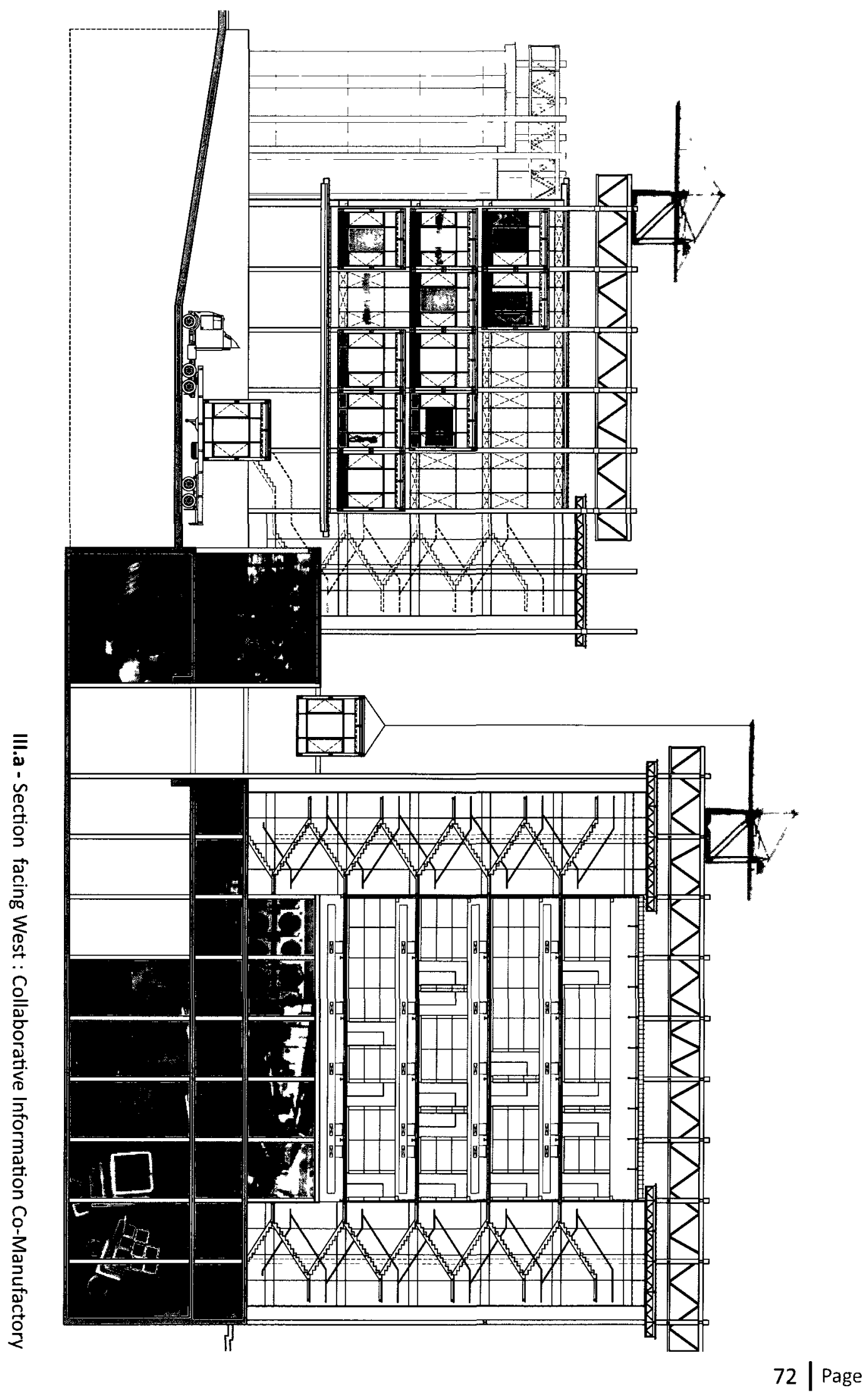




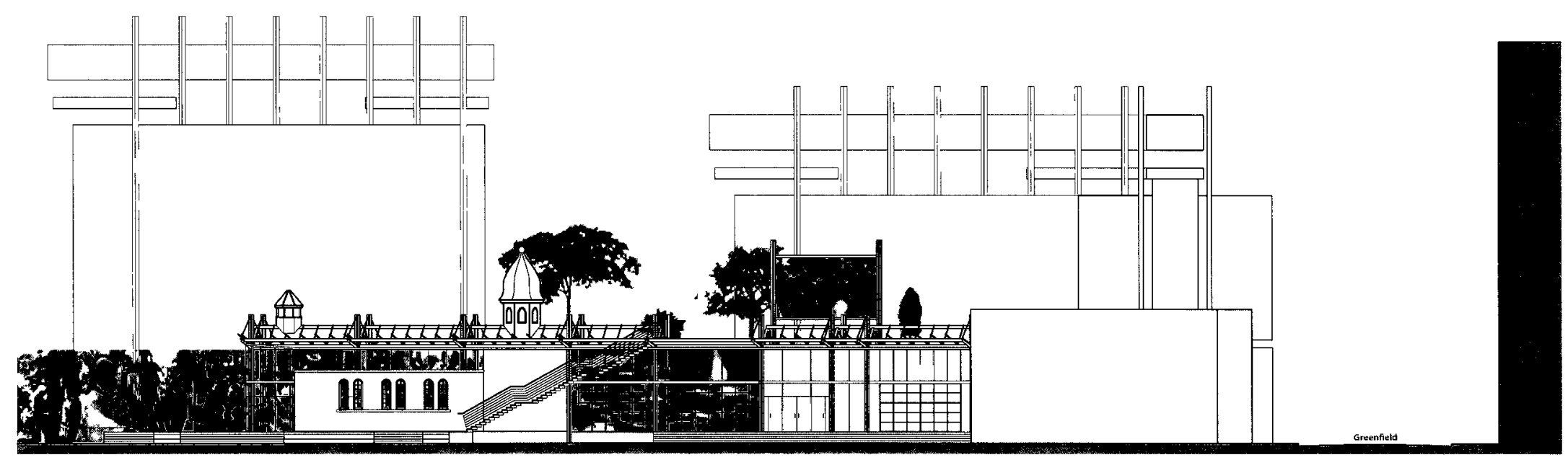

$\frac{n}{0}$
员
$\frac{0}{0}$
$\frac{2}{0}$
$\frac{1}{0}$
$: \frac{E}{E}$
$\equiv$
$\equiv$

III.b - Elevation facing East : Cultural Interpretation Mall 


\section{Initial Proposals}

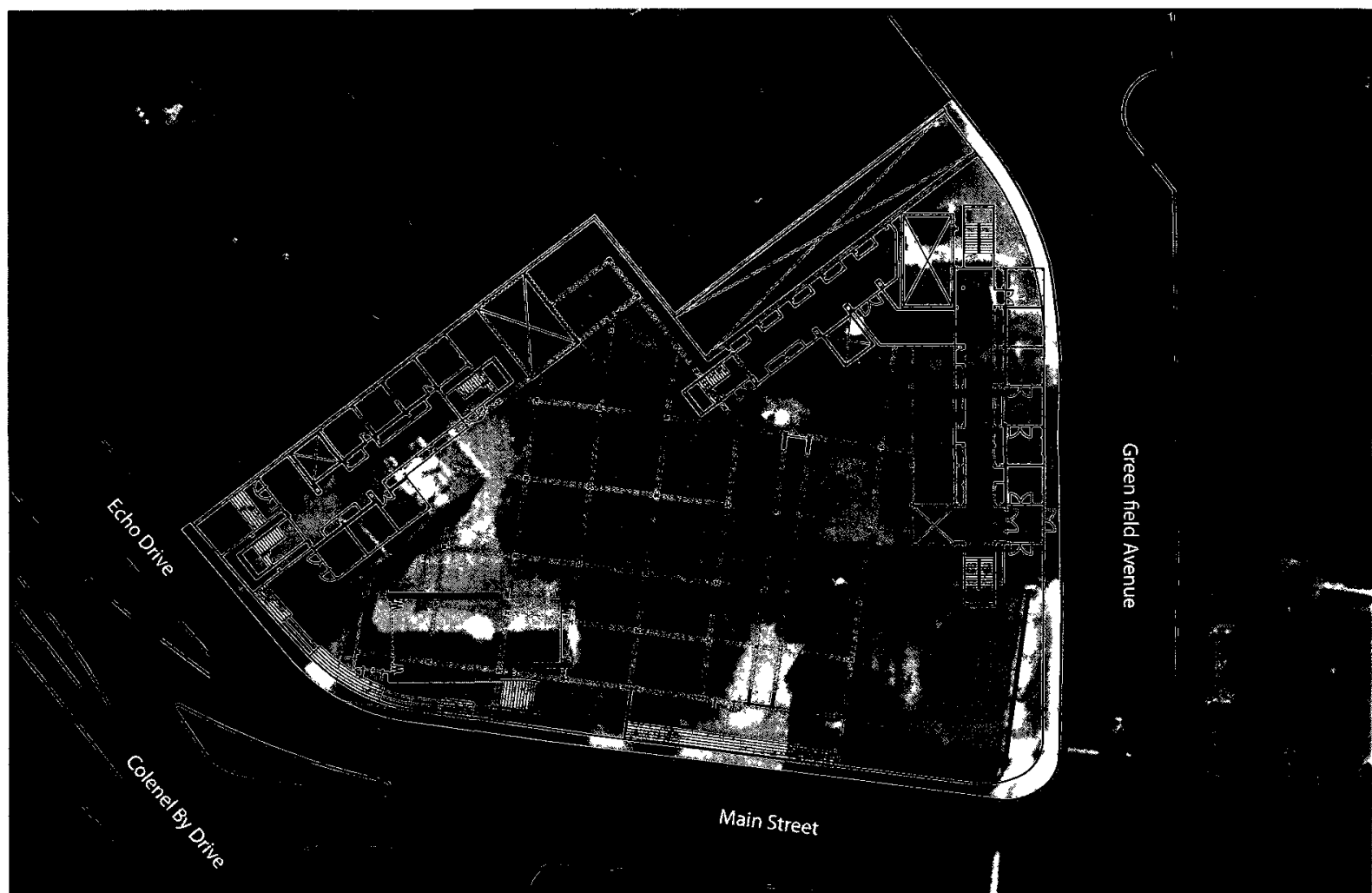

III.c (above) - Ground Floor Plan: Collaborative Information Co-Manufactory
III.d (below) - Third Floor Plan: Indeterminate

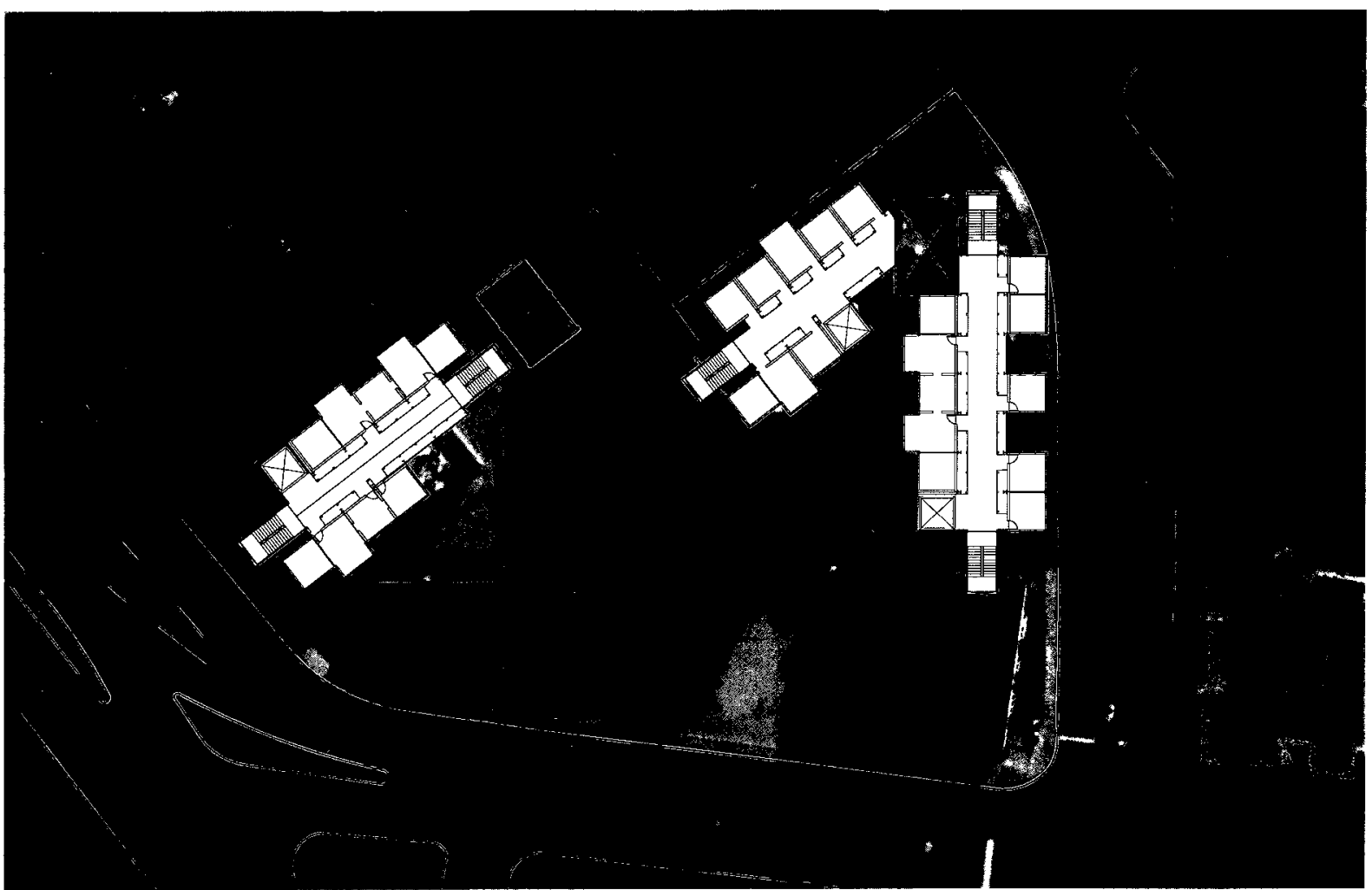




\section{Initial Proposals}
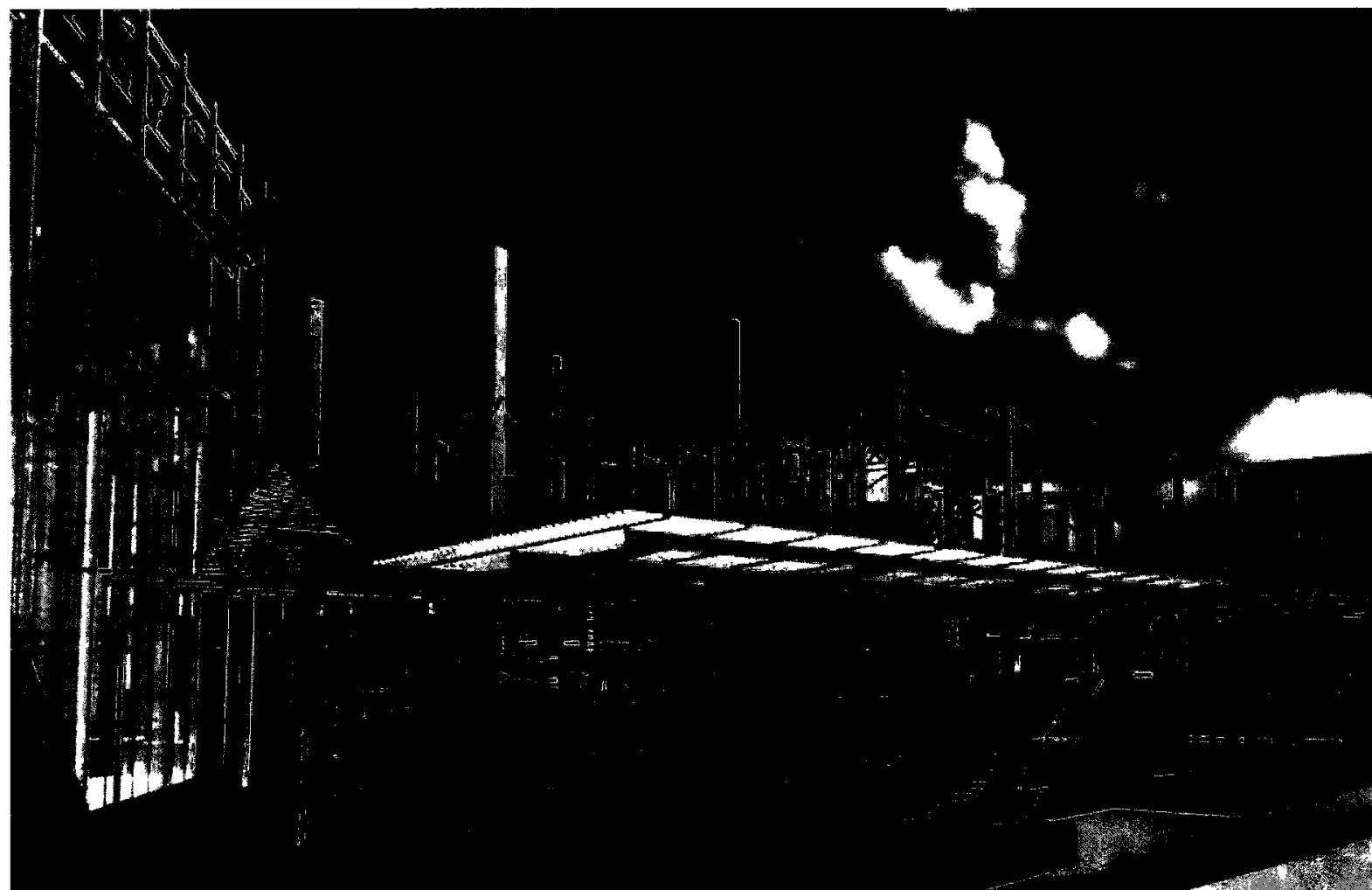

III.e (above) - Perspective View : Cha-

III.f (below) - Perspective View: pel additions from Echo and Main.

"Market" space on Main Street

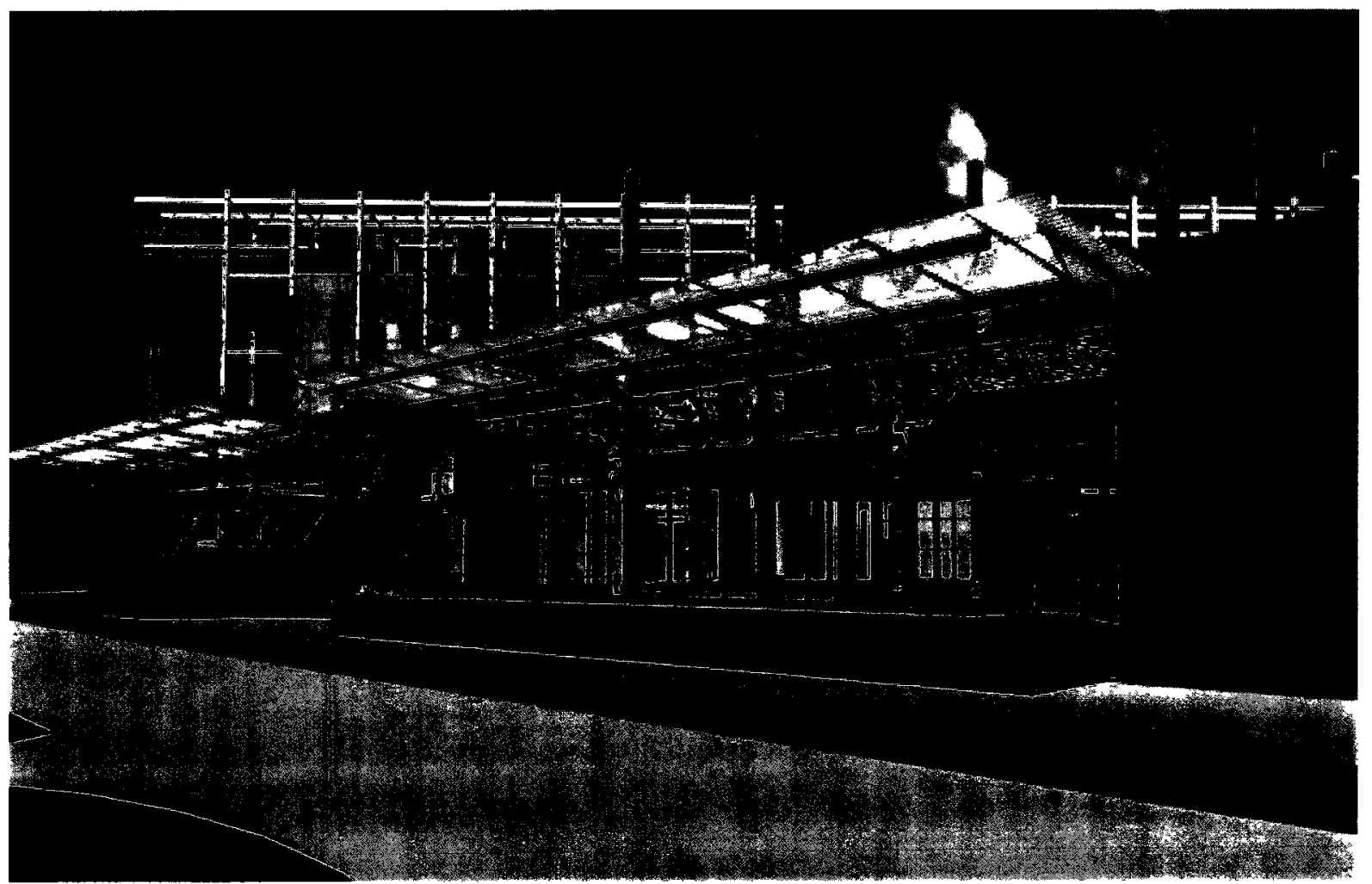




\section{Initial Proposals}

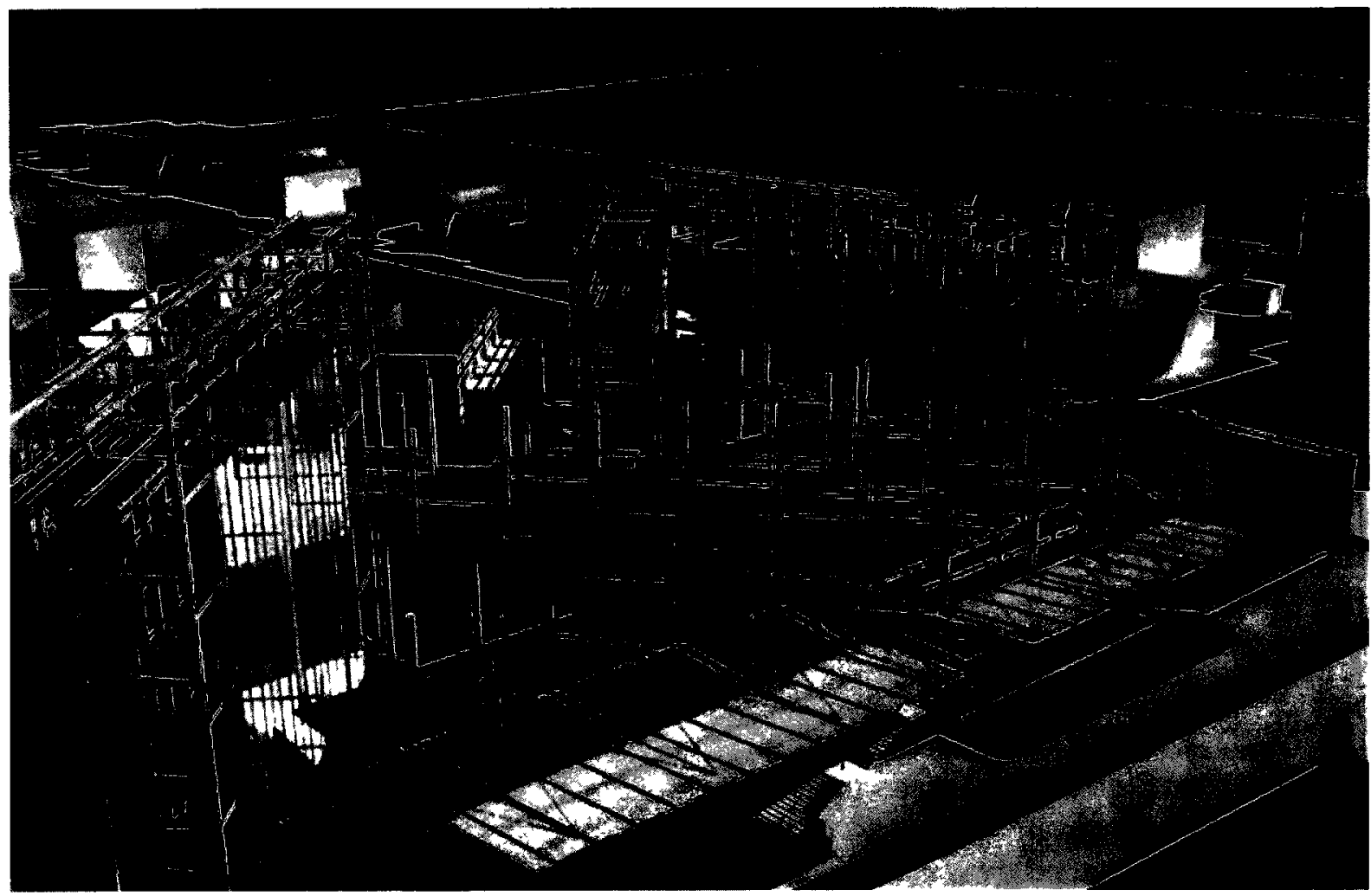

III.g (above) - Aerial View: Housing Infrastructure from Northwest
III.h (below) - Aerial View : Housing infrastructure and public court from Southwest

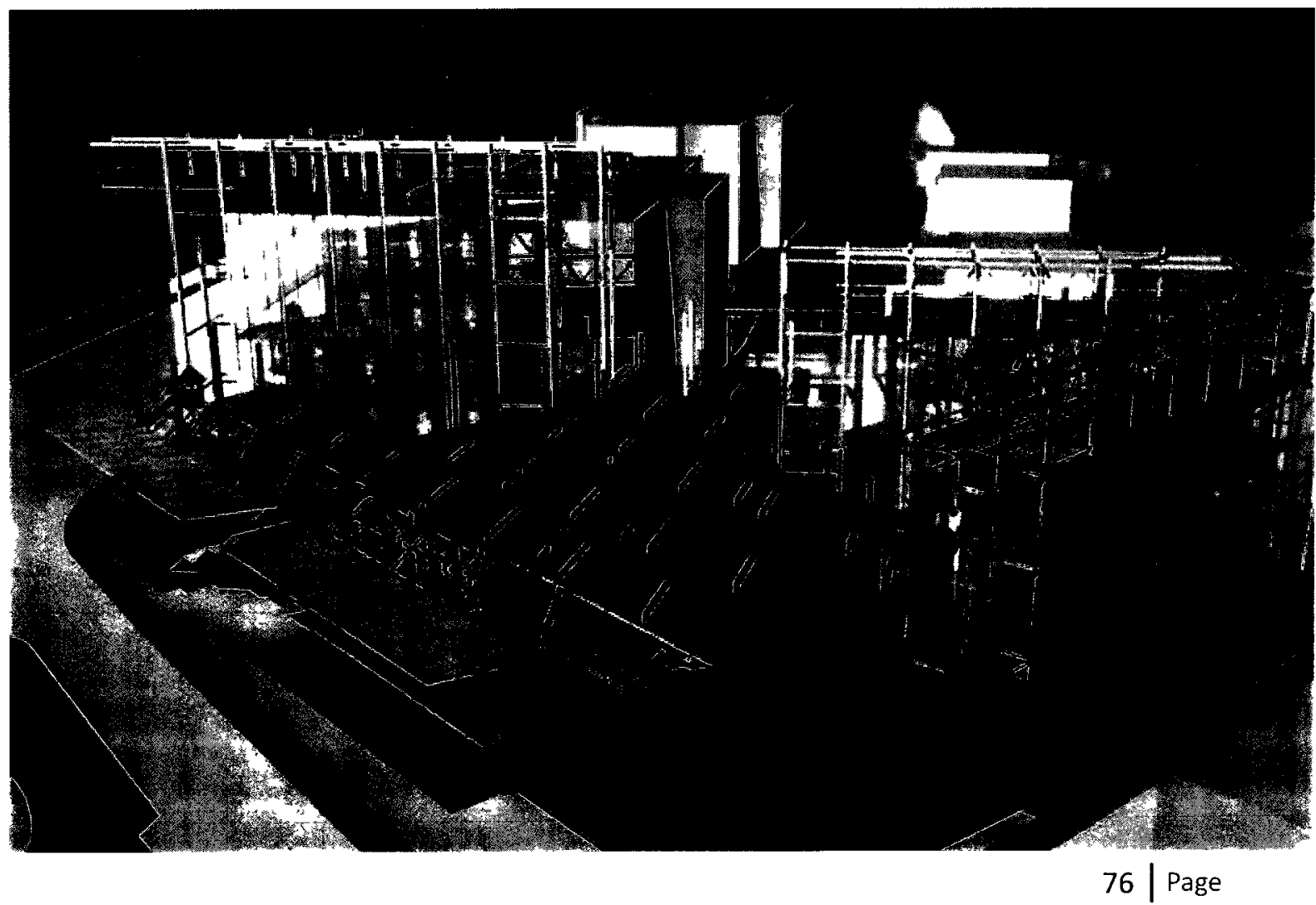


IV. Final Proposal

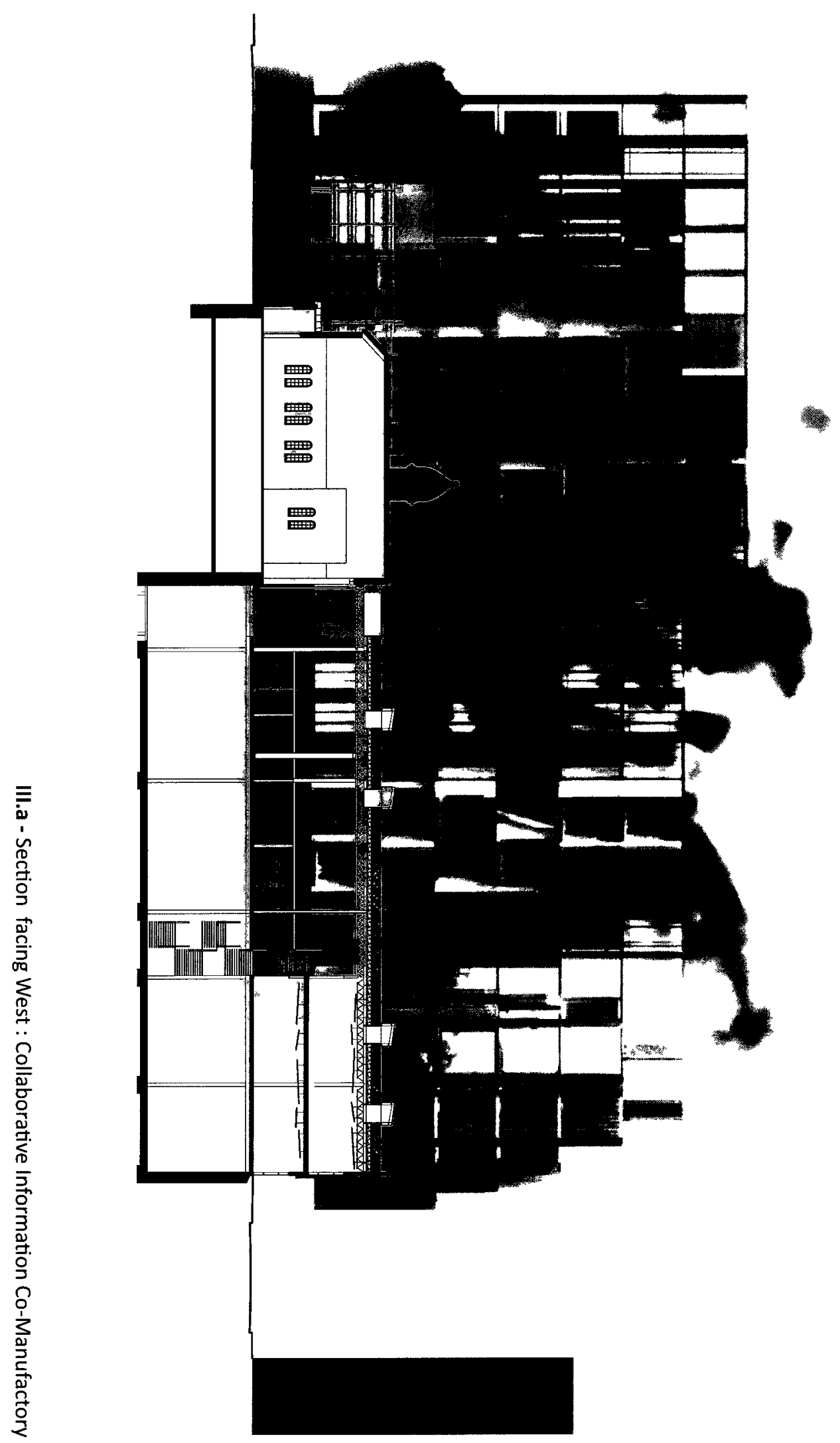




\section{Final Proposal}

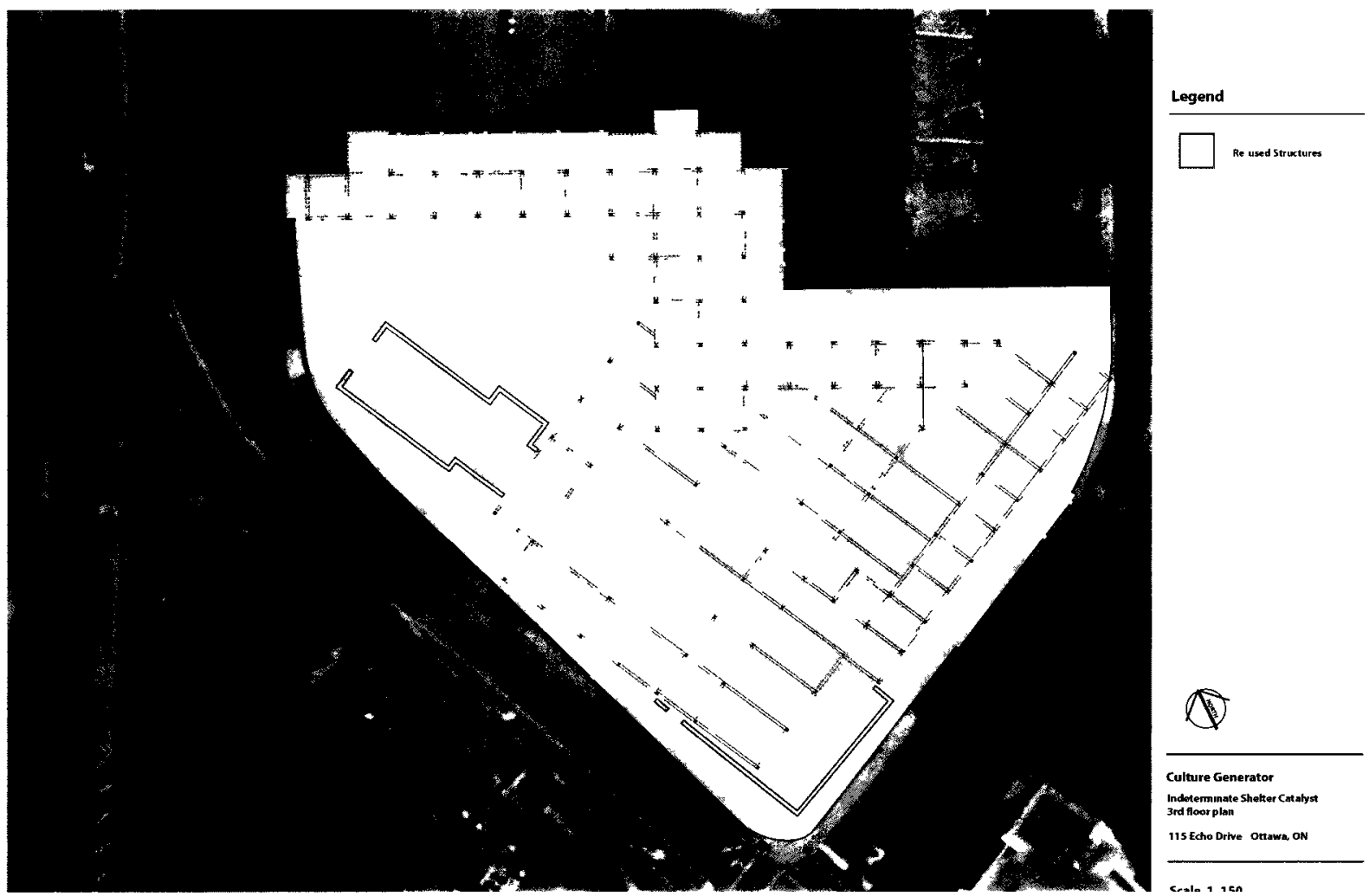

III.b (above) - Ground Floor Plan: Exısting III.c (below) - Ground Floor Plan Buildıngs and Proposed Infrastructure

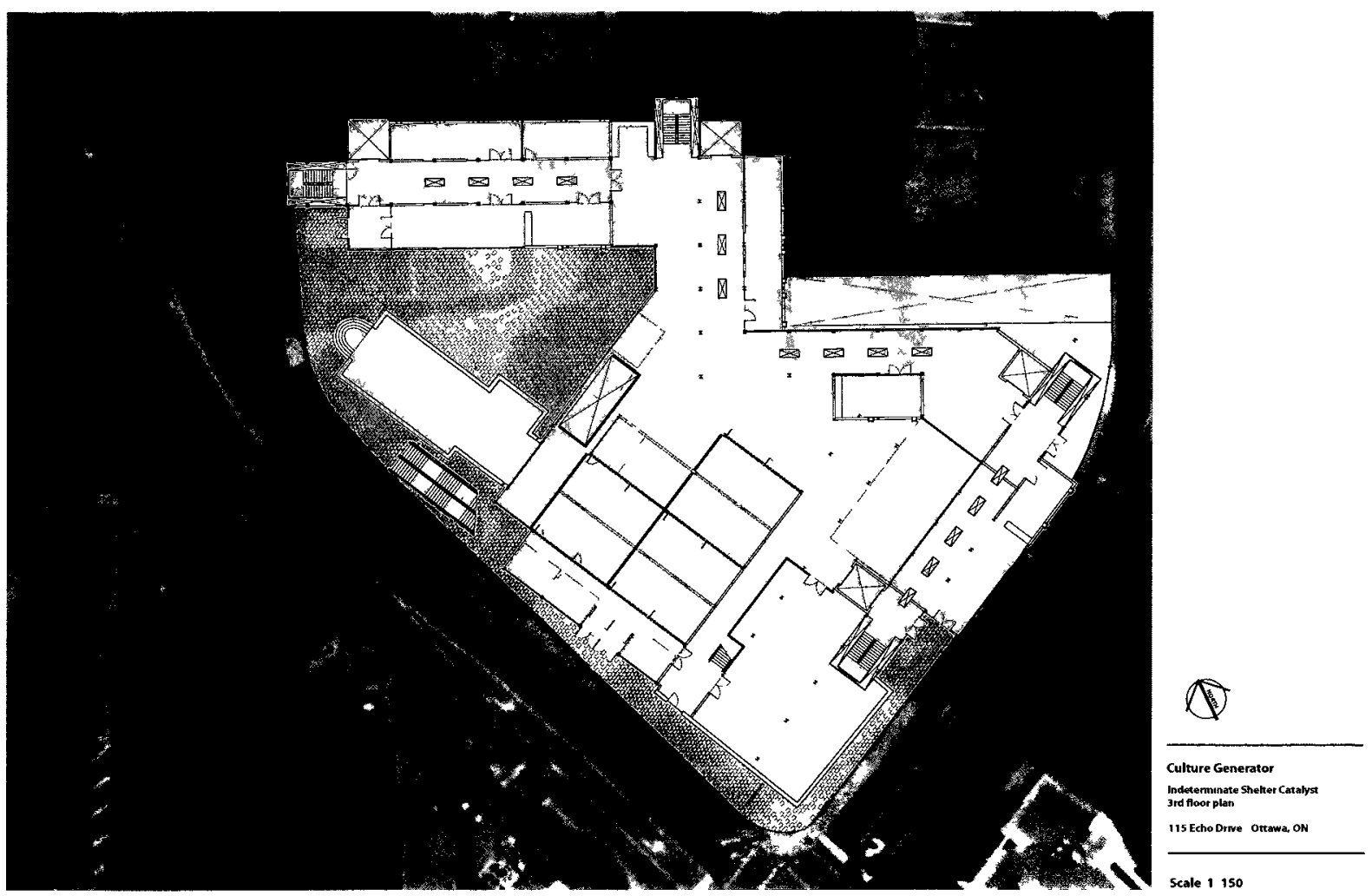




\section{Final Proposal}

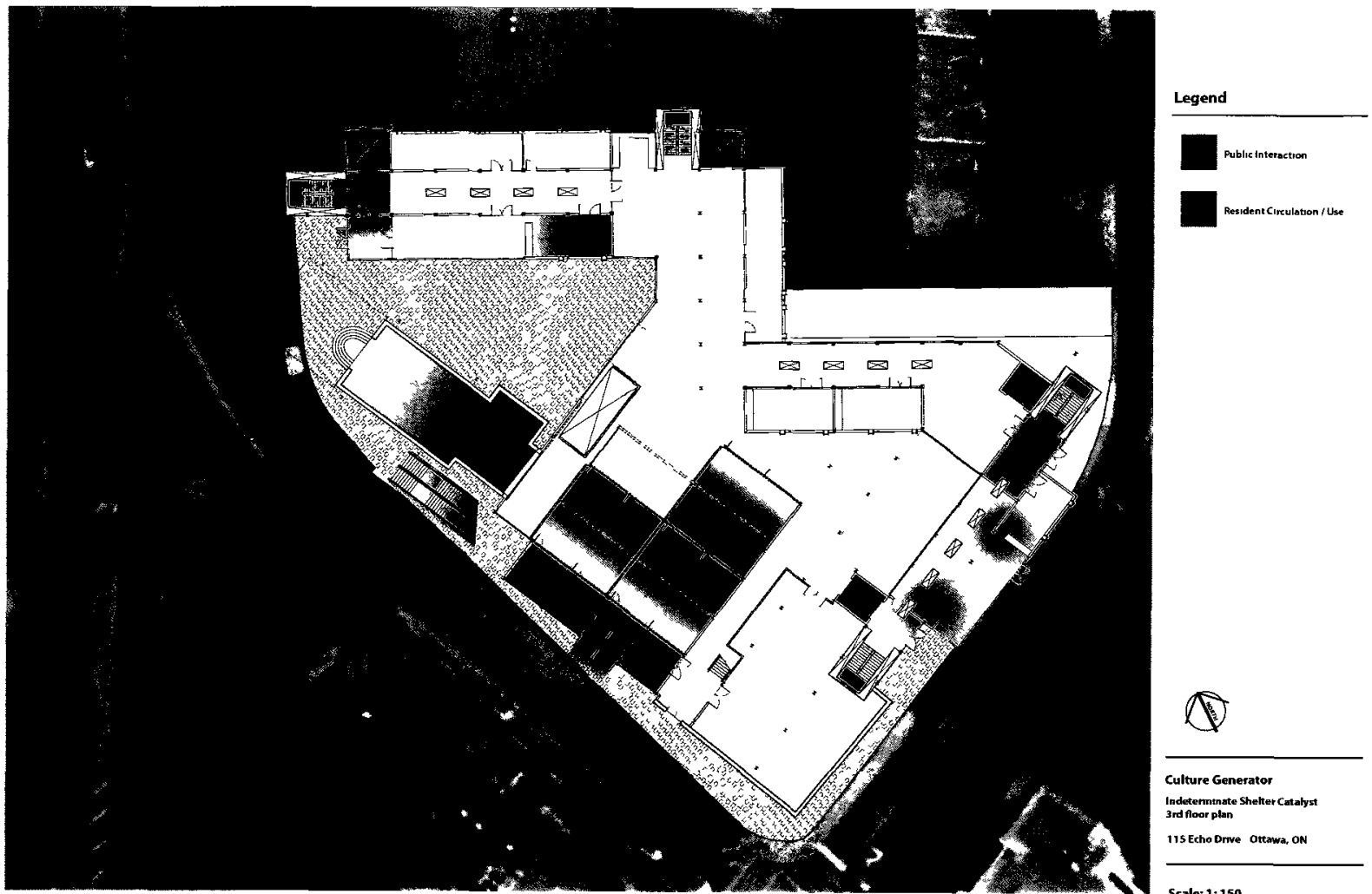

III.d (above) - Ground Floor Plan: Tenant / Community Interaction
III.e (below) - Ground Floor Plan: Tenant /Community Interaction

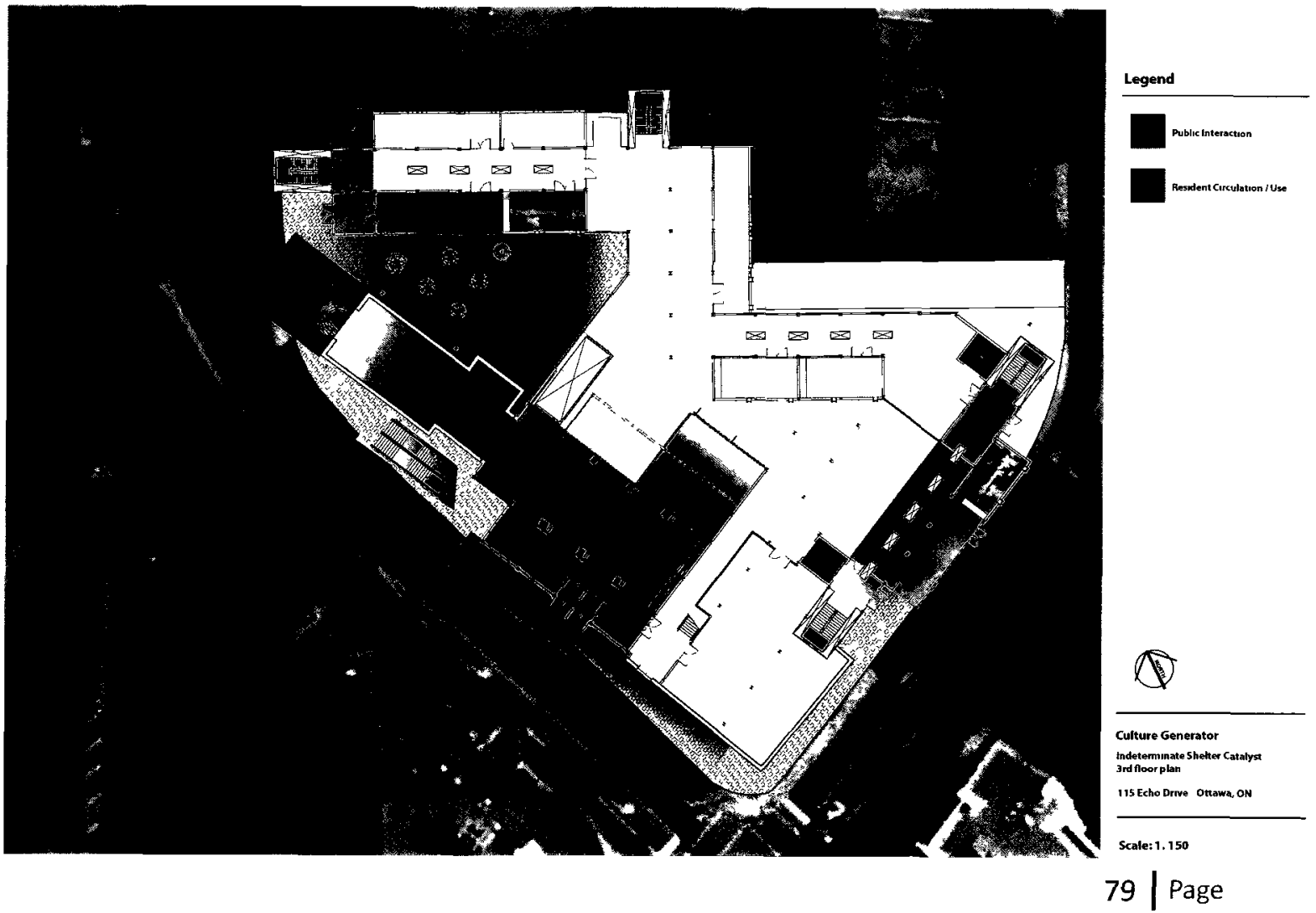




\section{Final Proposal}

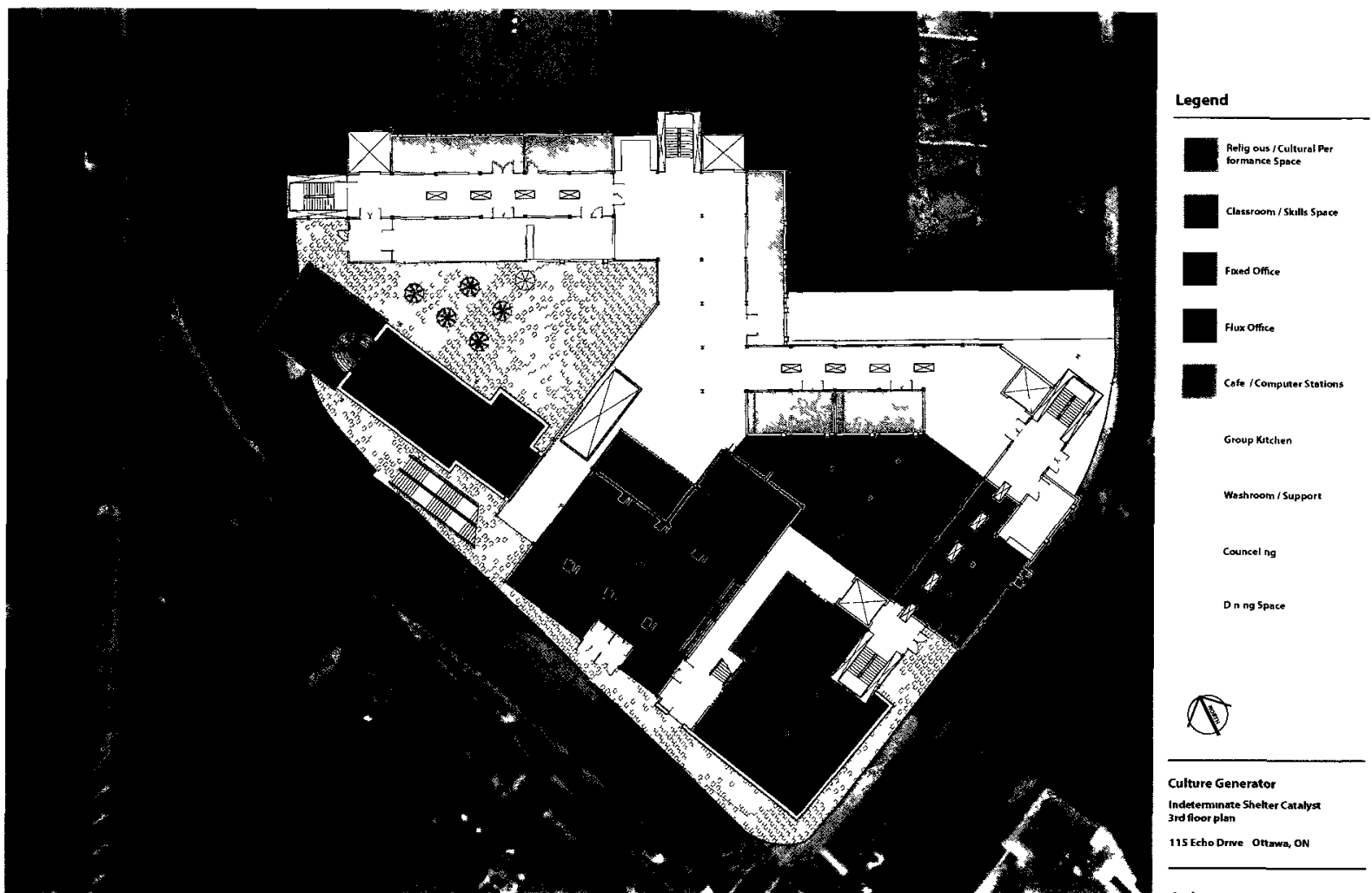

III.f (above) - Ground Floor Plan: Allocation of Programs
III.g (below) - Ground Floor Plan: Allocation of Programs

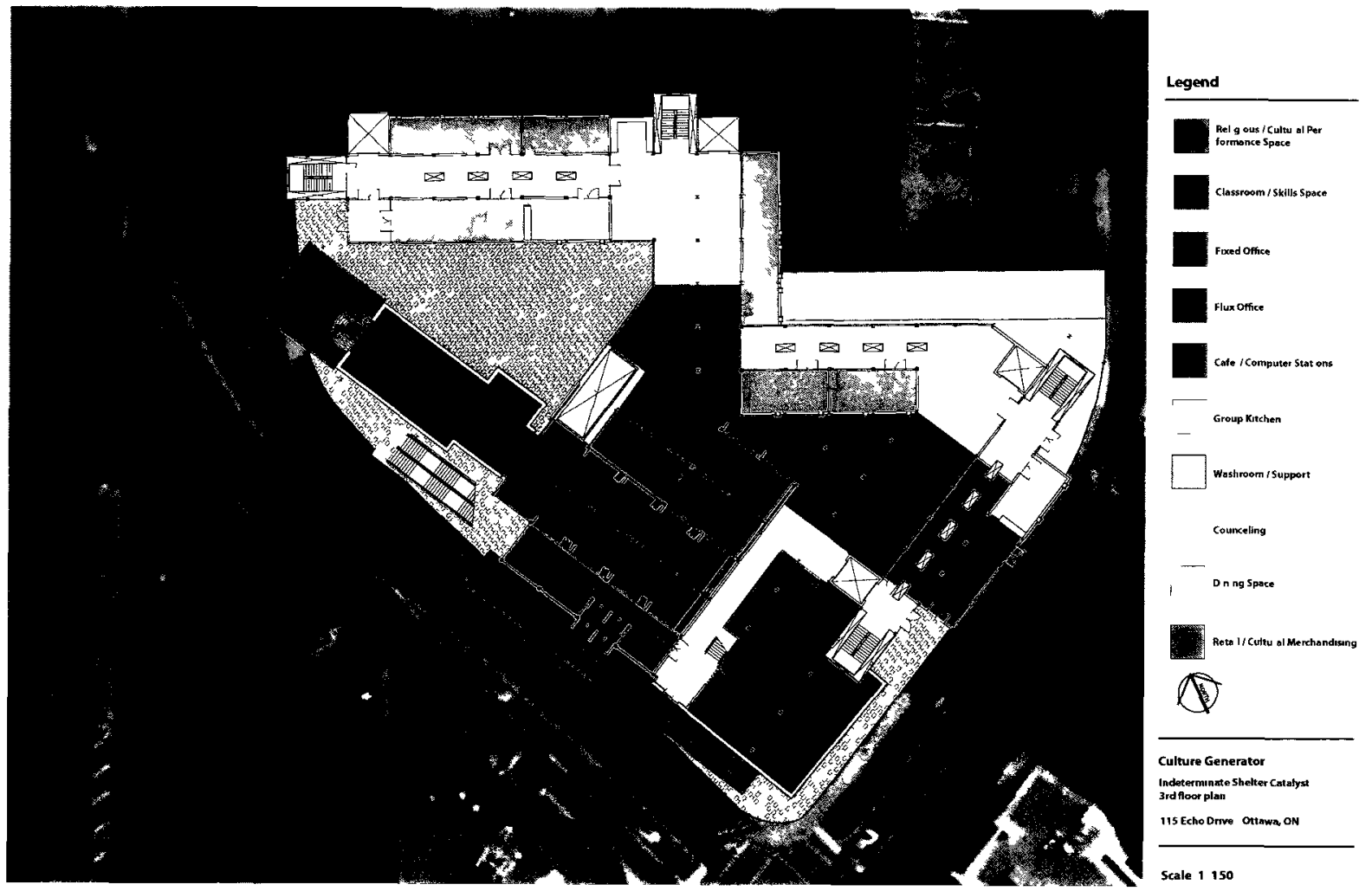

$80 \mid$ Page 


\section{Final Proposal}

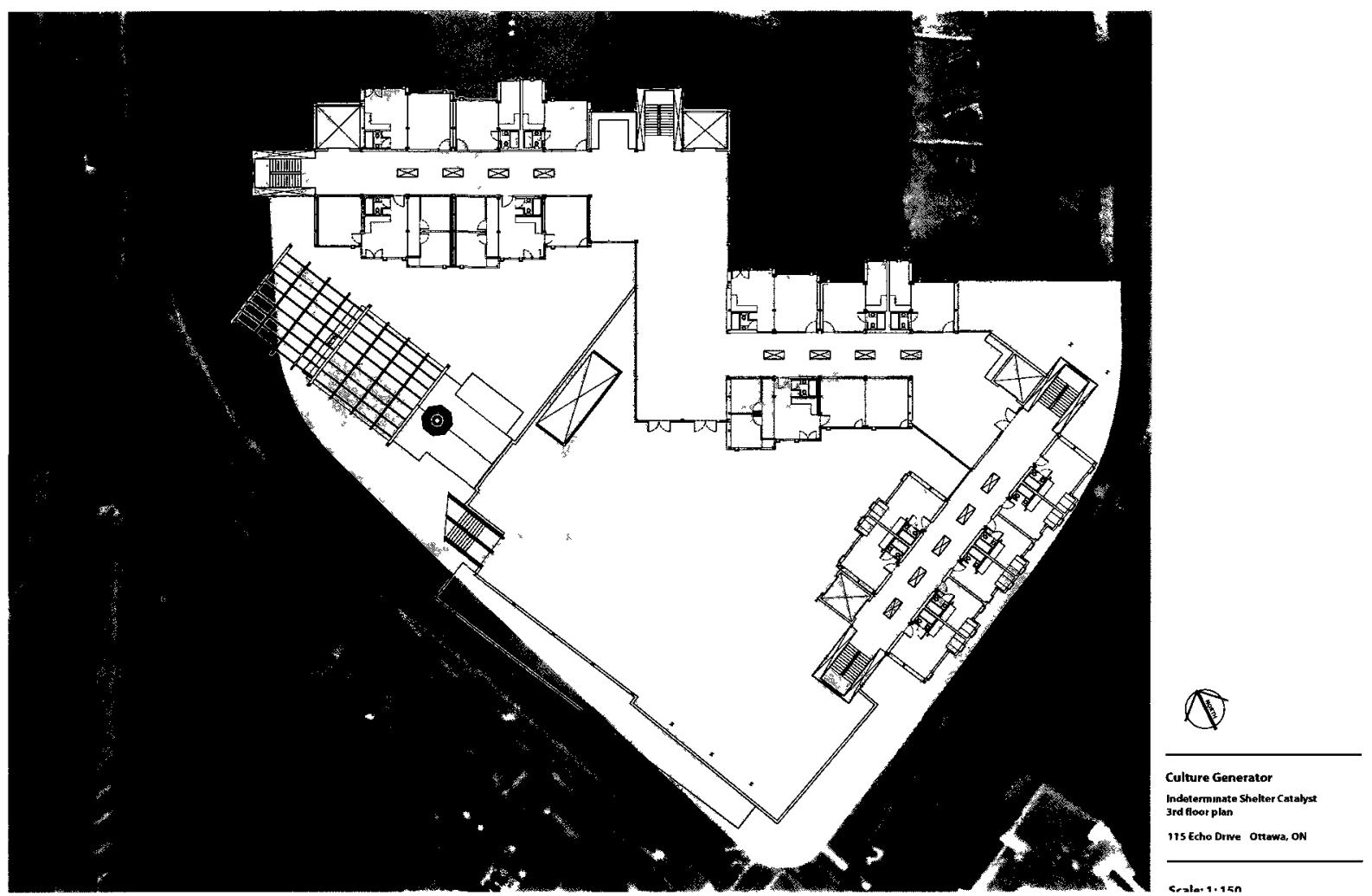

III.i (below) - Third Floor Plan: Modular Infrastructure

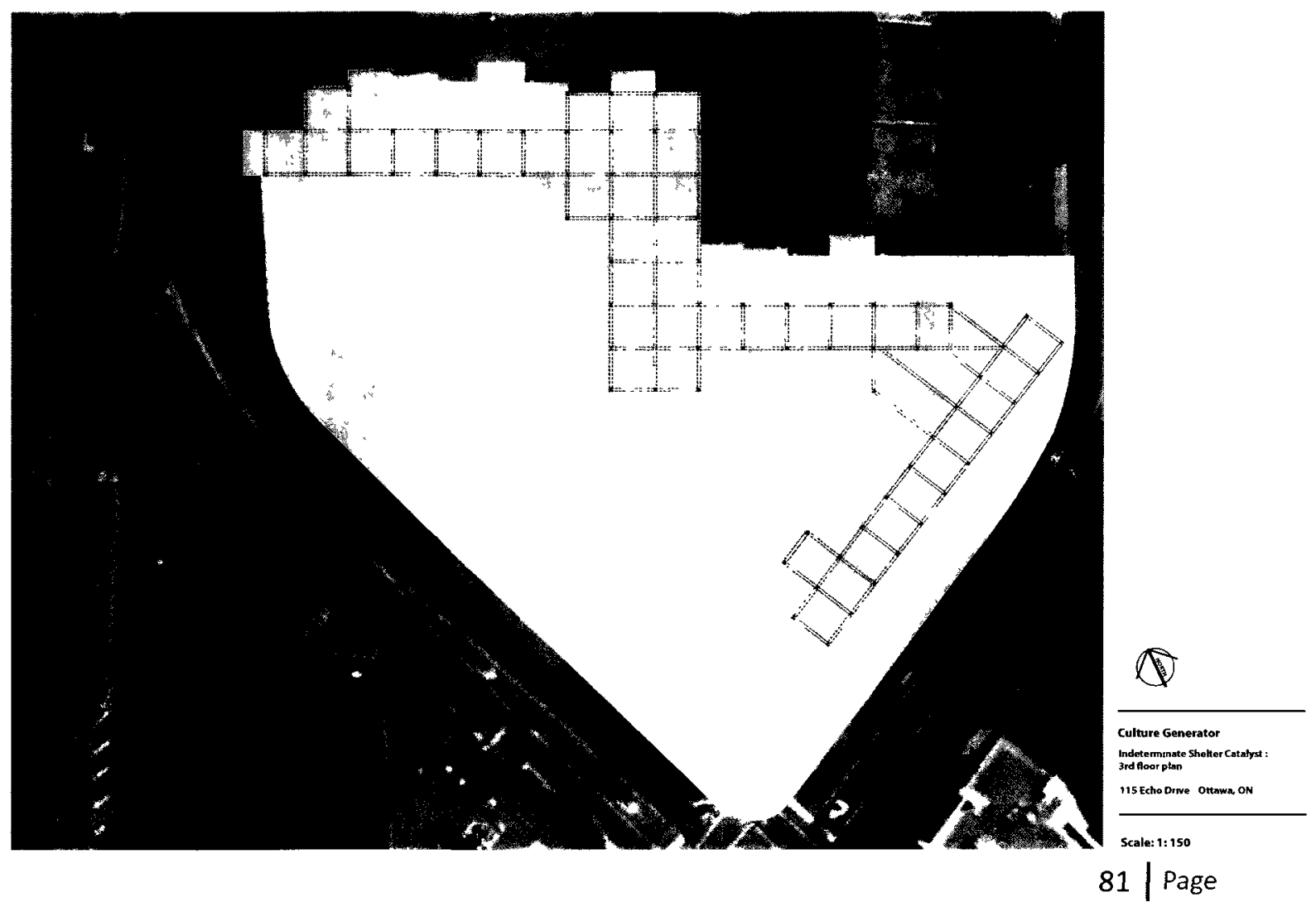




\section{Final Proposal}

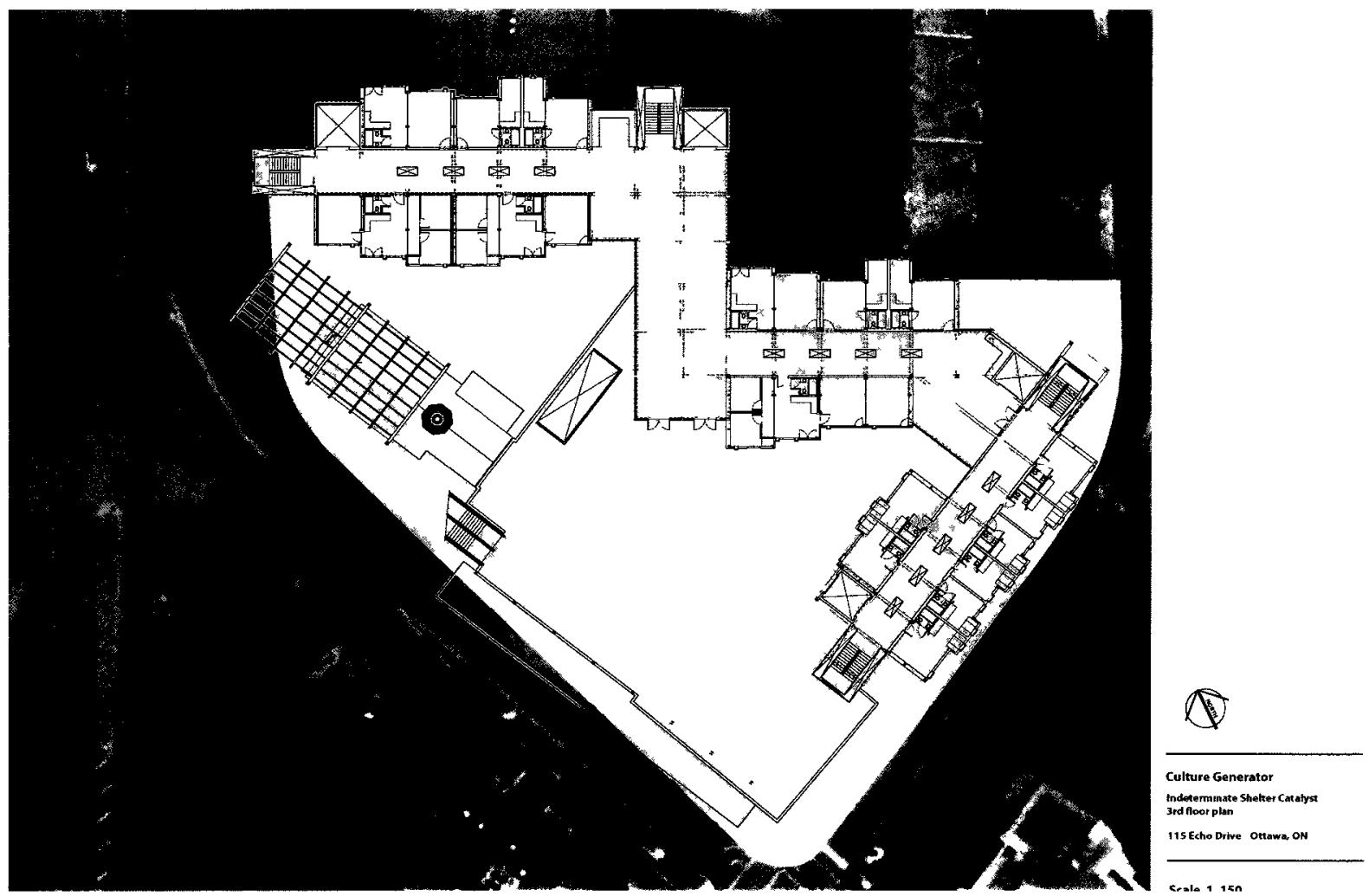

III.j (above) - Thırd Floor Plan

III.k (below) - Thırd Floor Plan: Plug and Play Services

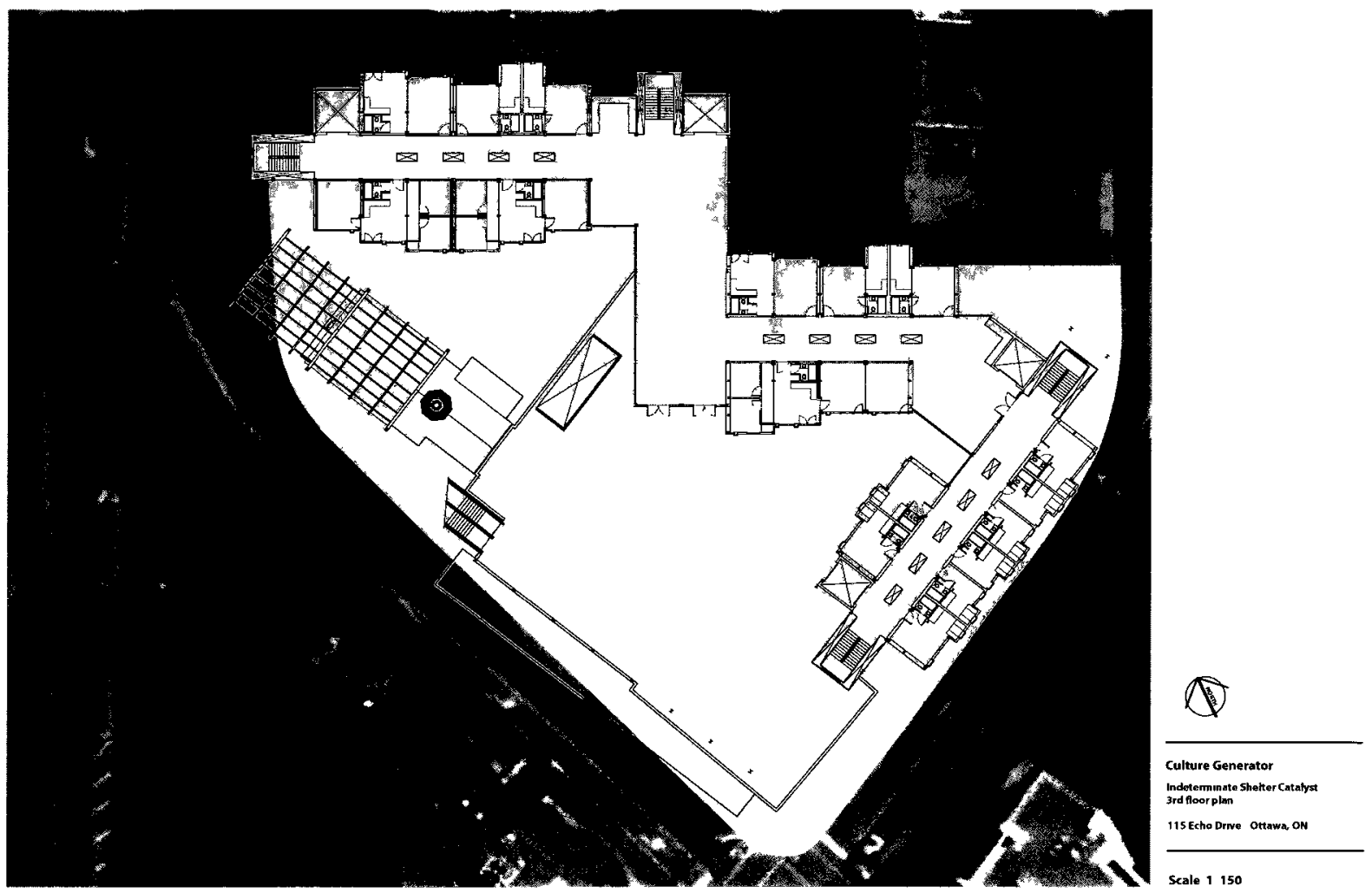




\section{Final Proposal}

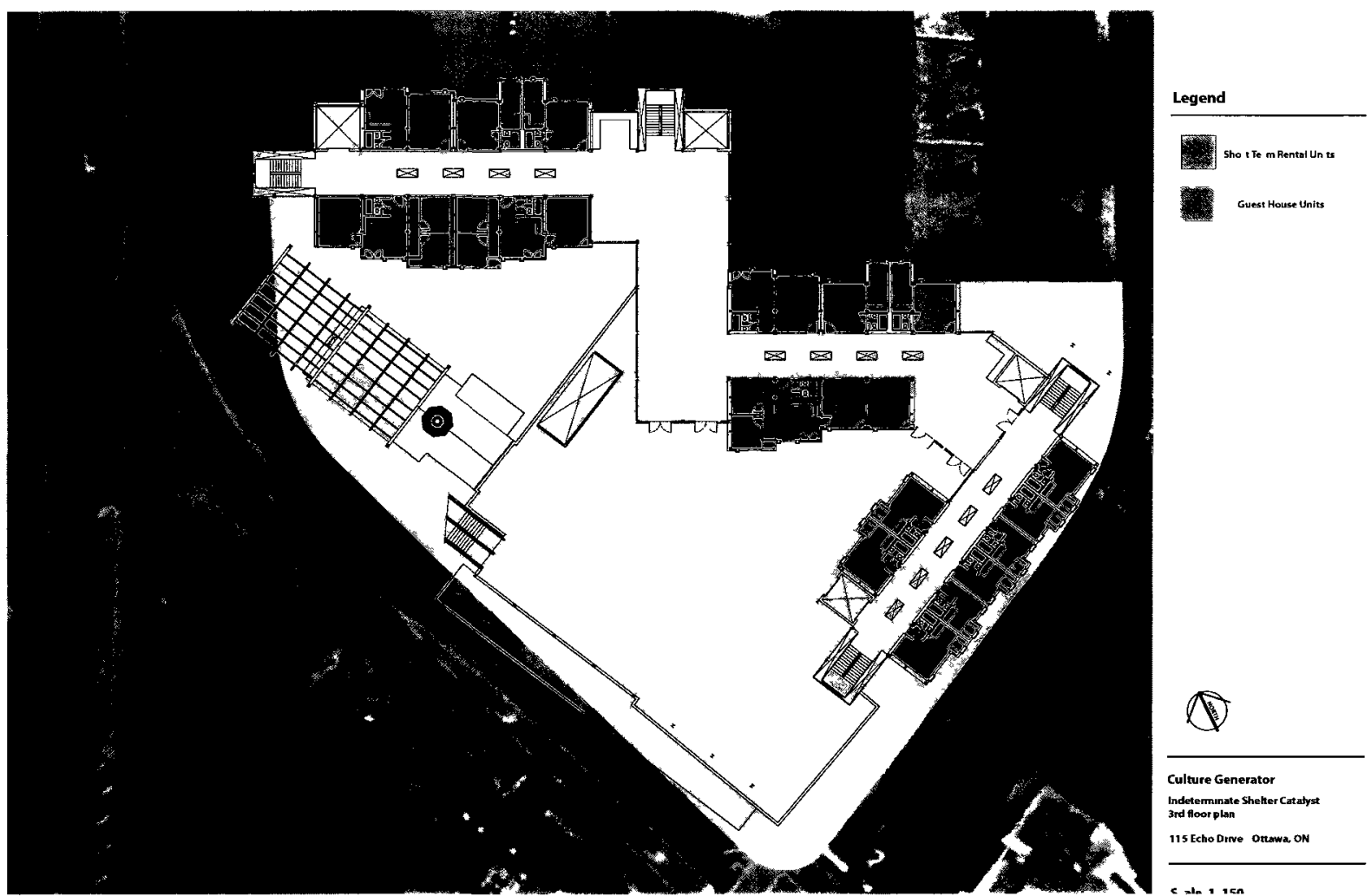

III.I (above) - Thırd Floor Plan: Guesthouse and Transitional Housing Units
III.m (below) - Thırd Floor Plan: Modular Unit Combınations and Typologies

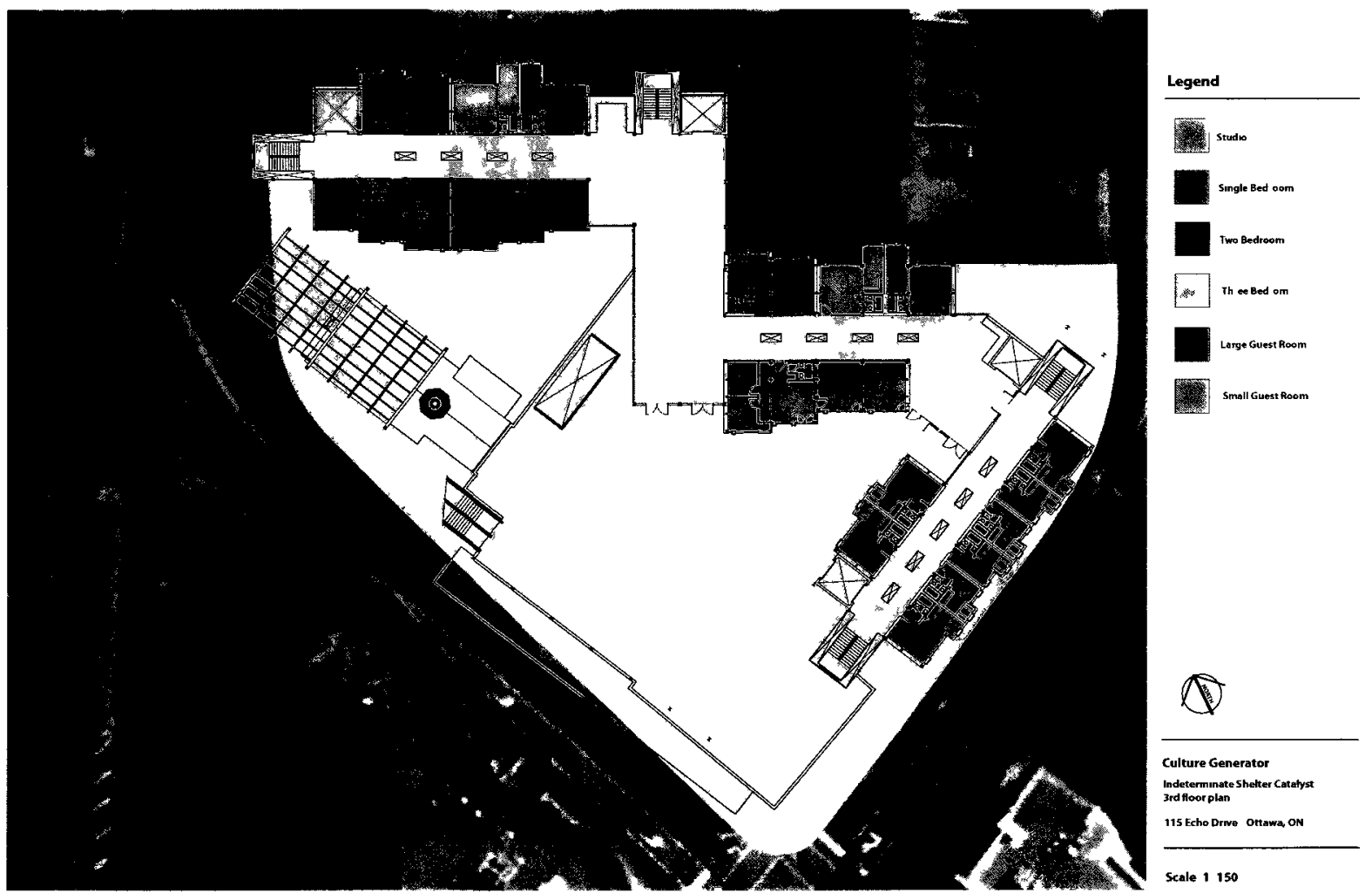




\section{Final Proposal}

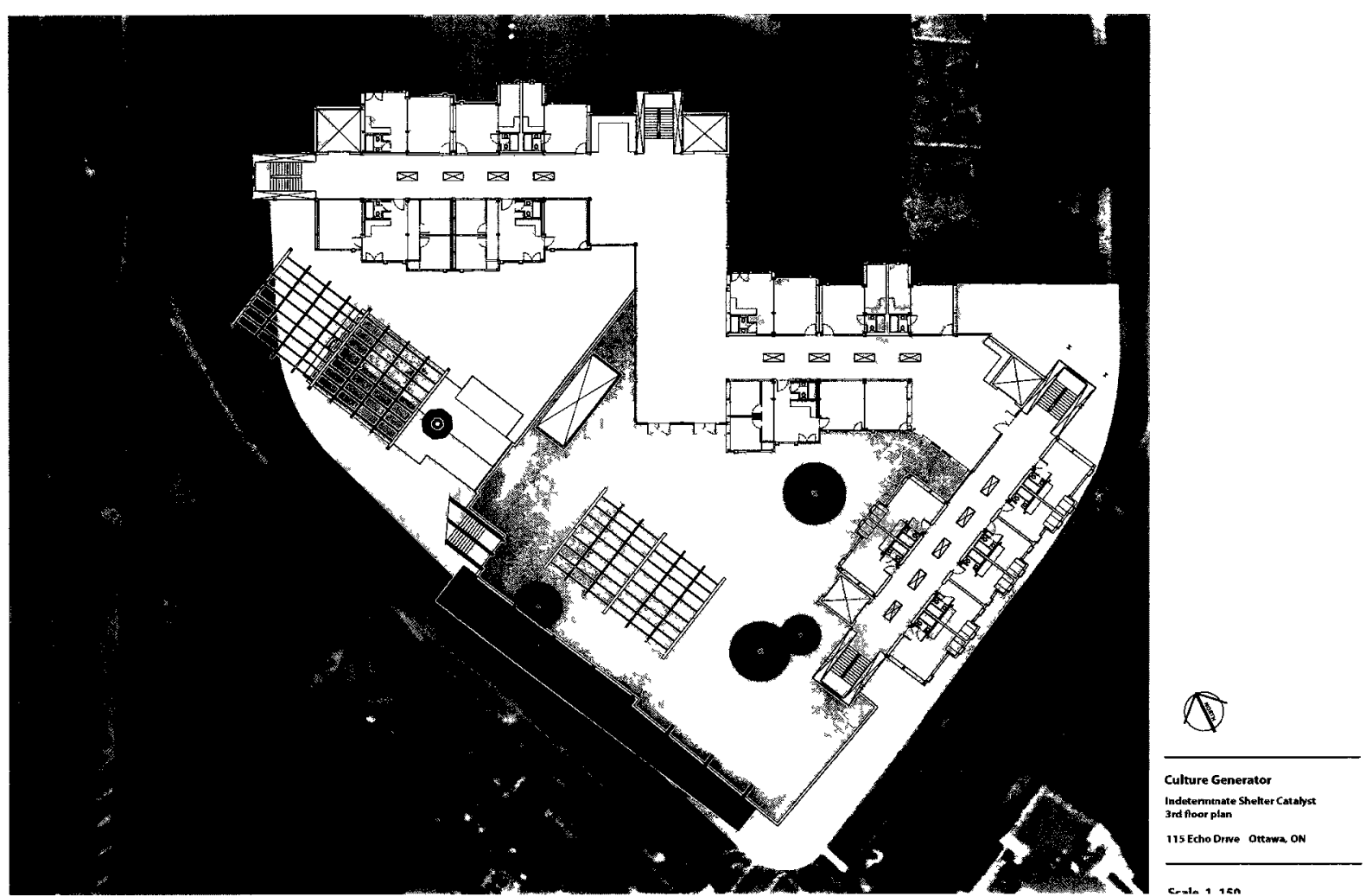

III.n (above) - Third Floor Plan: Residual Interactive Space

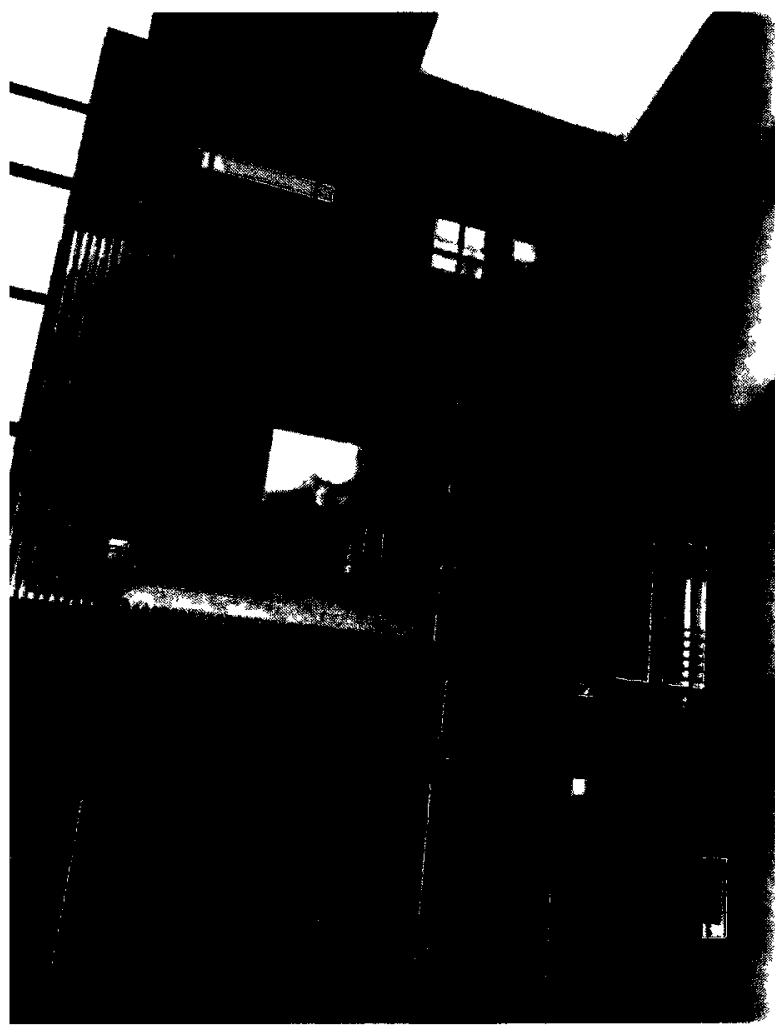

III.o (below) - Perspective: Modular Housing and Resulting Variability
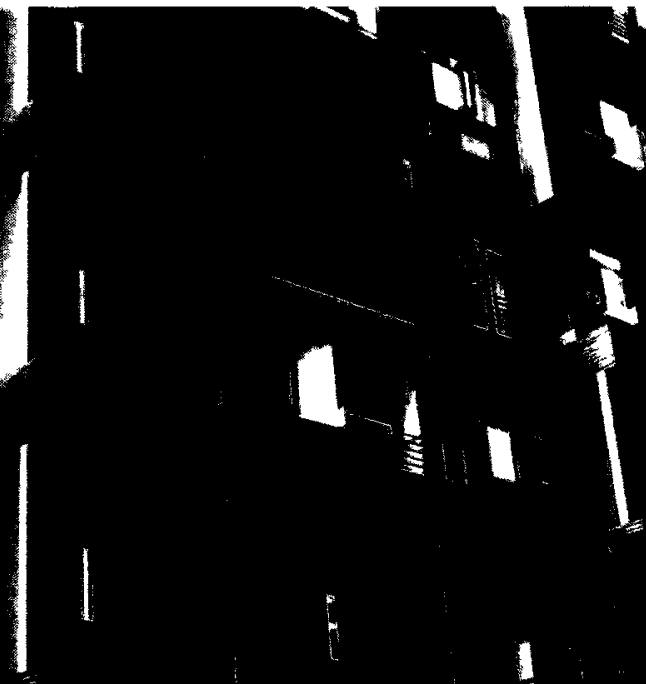

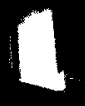

1, (4)
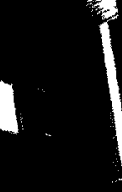

1

4<smiles>[C]1[C]C1</smiles>

4

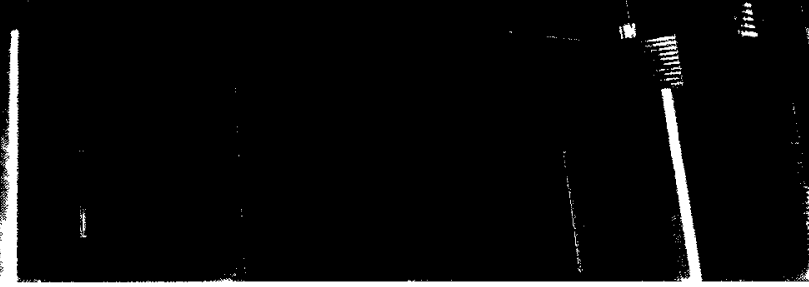

84 | Page 


\section{Final Proposal}

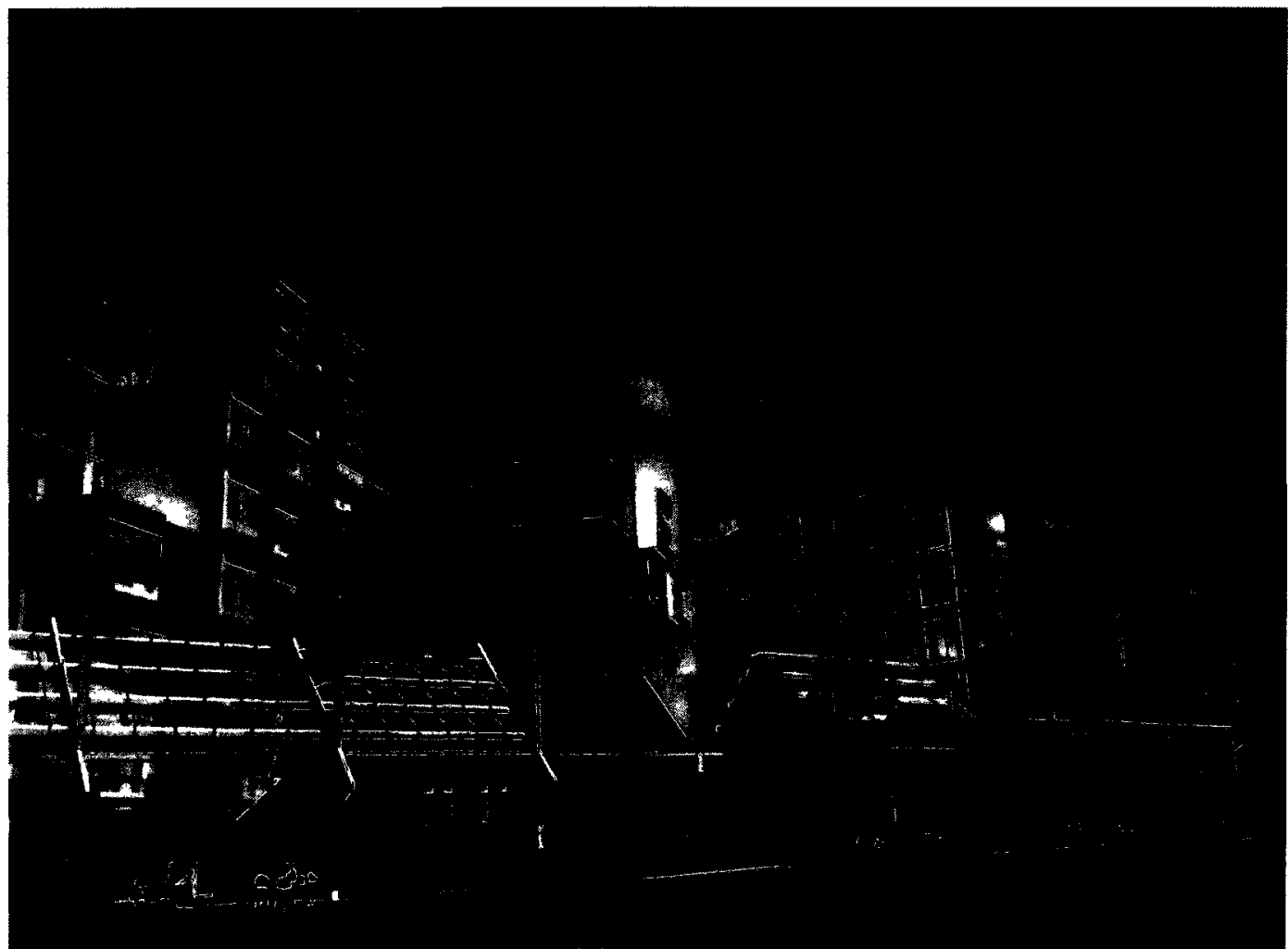

III.p (above) - Perspective: From Colonel By and Main Street
III.q (below) - Perspective : Main Street Public Entry

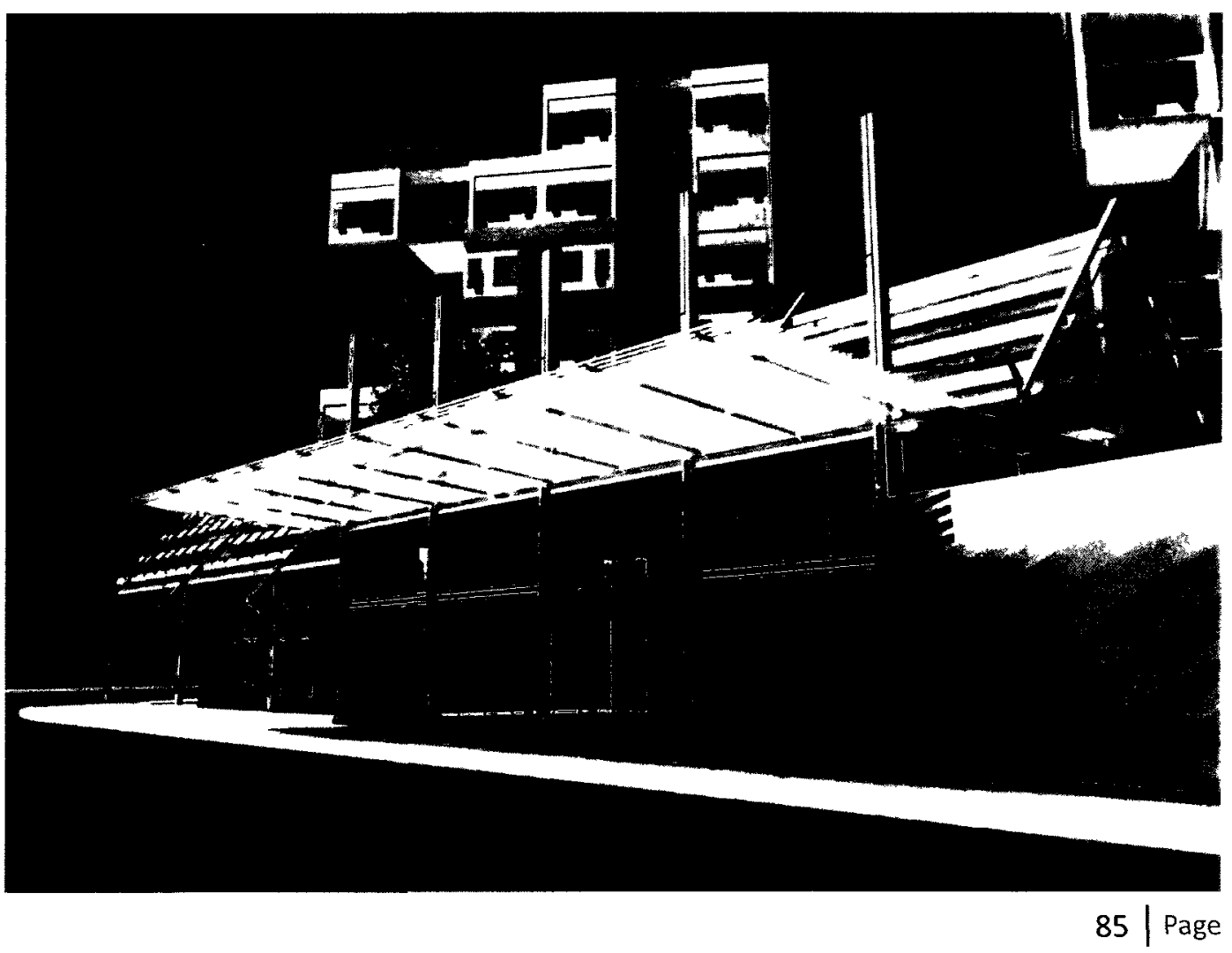




\section{Final Proposal}
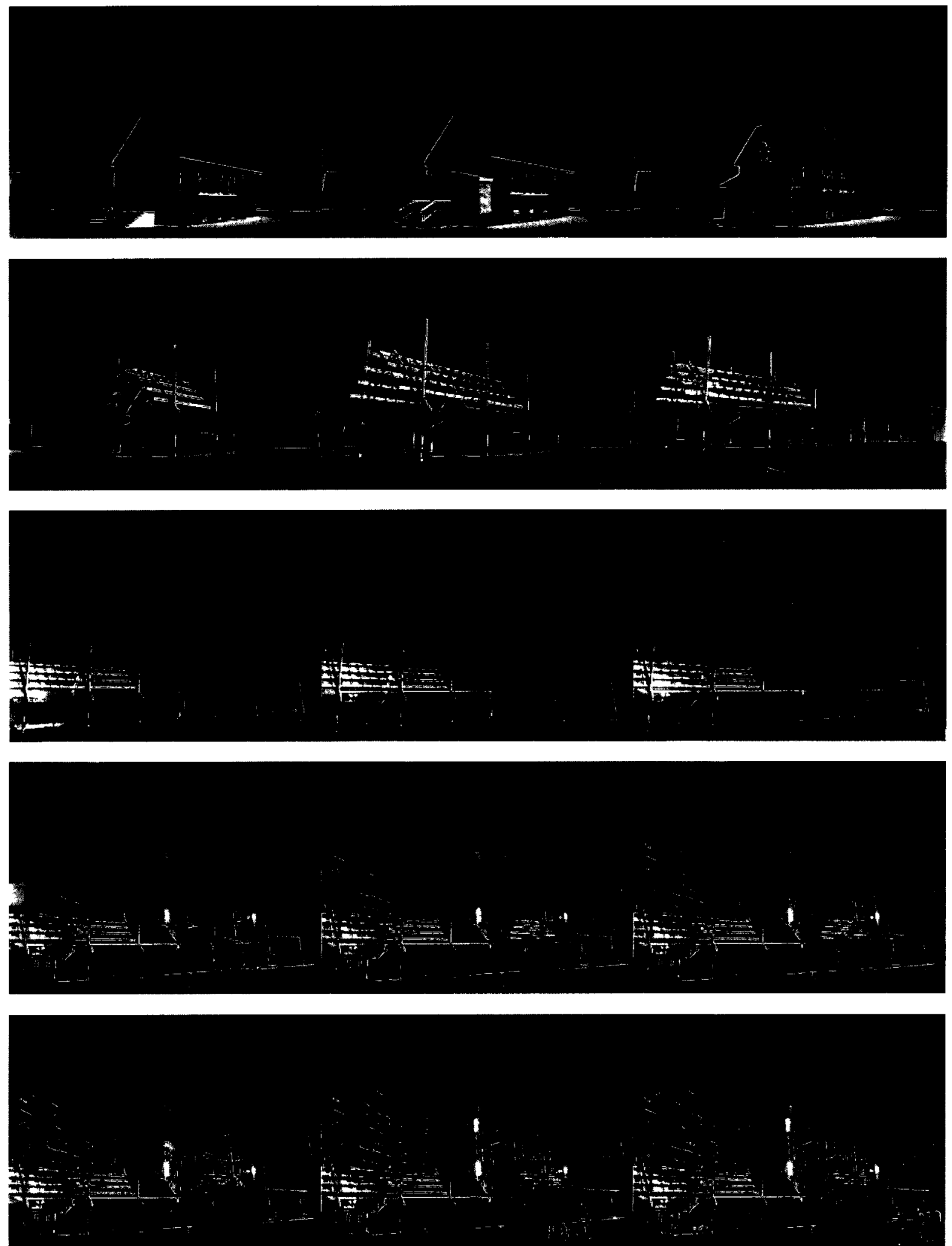

III.r (all) - Film Stills: Ongoing Adaptation 


\section{Final Proposal}
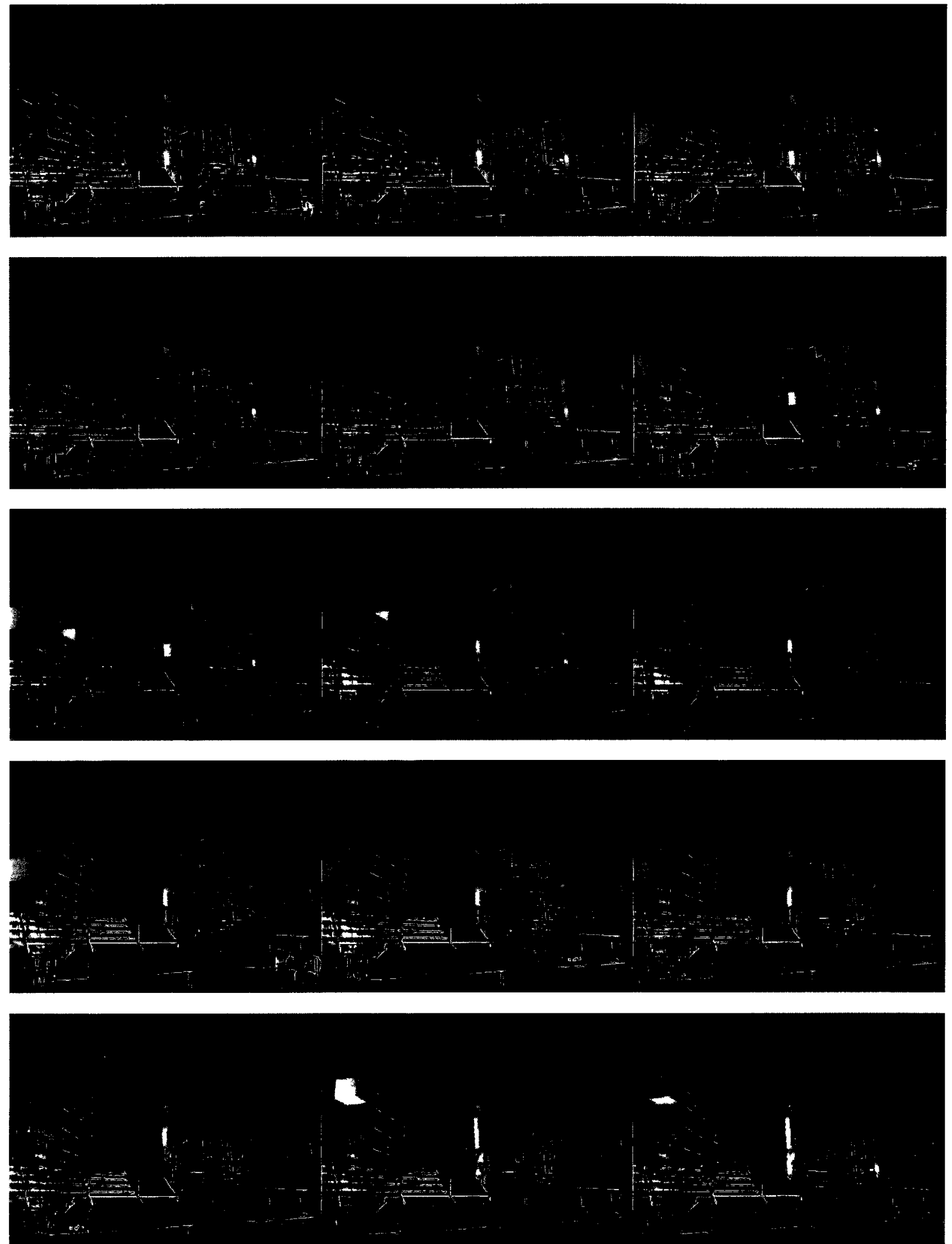

III.r (all) - Film Stills: Ongoing Adaptation 


\section{Final Proposal}

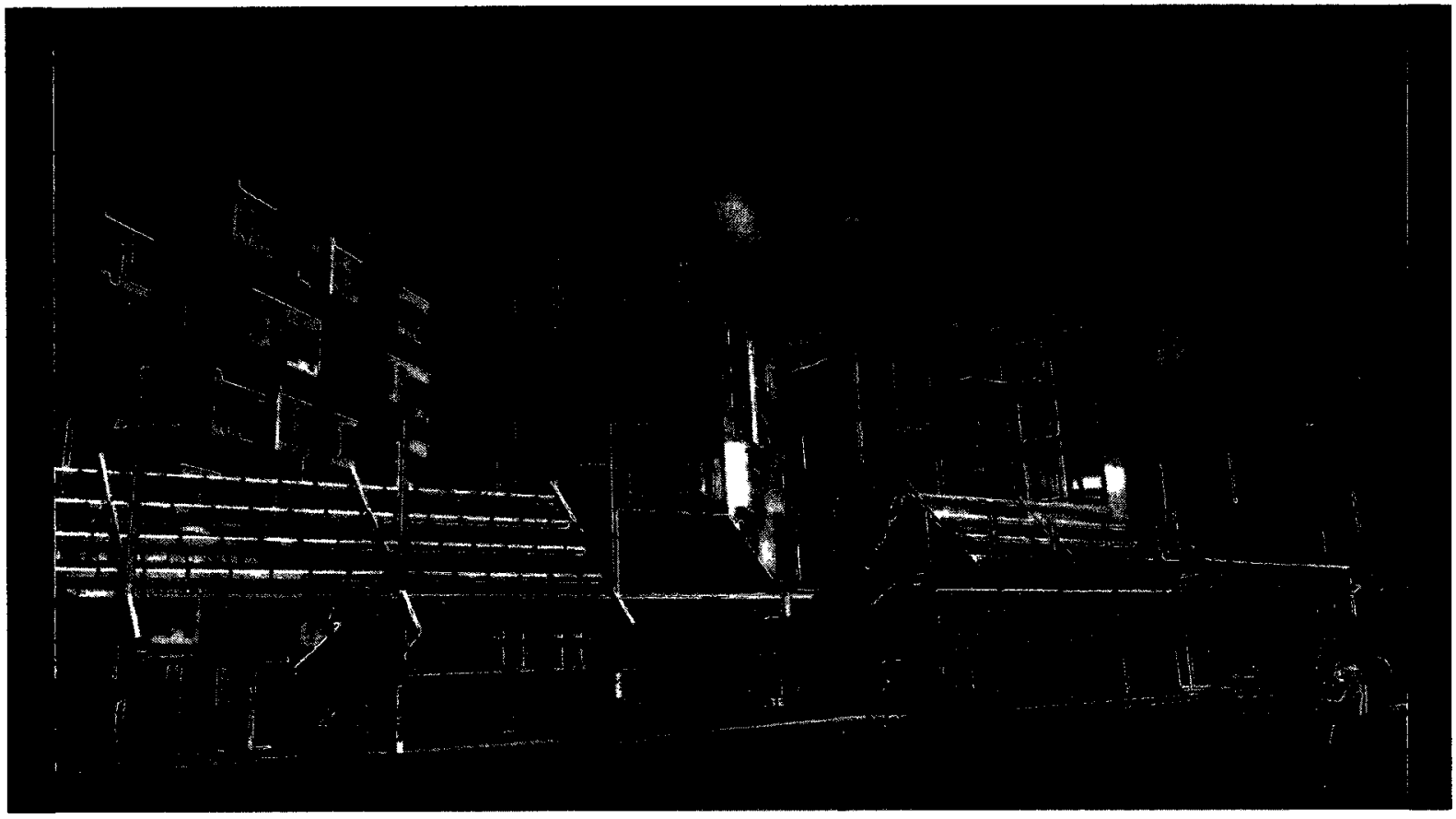

III.s (above) - Film Still

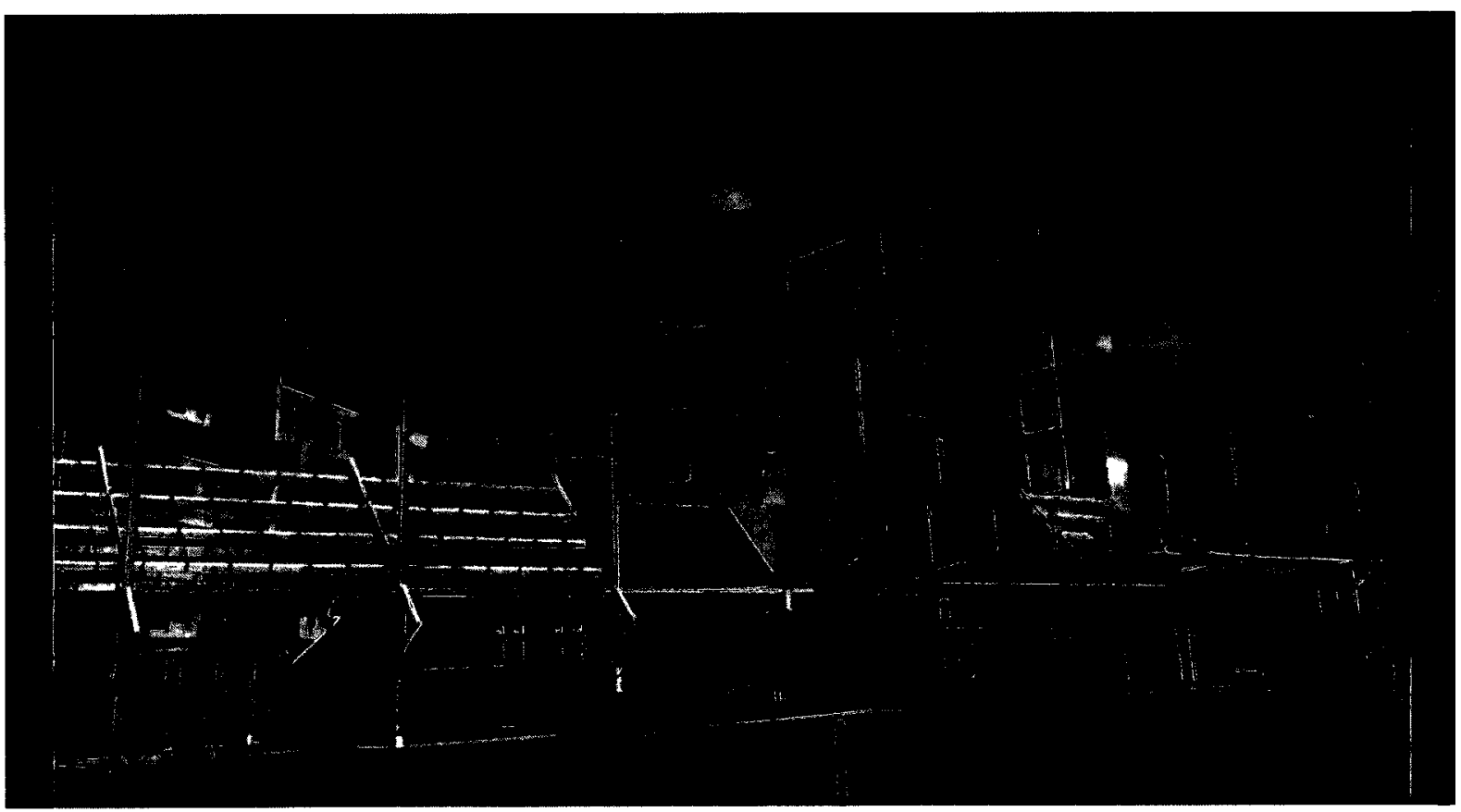

III.t (above) - Film Still 


\section{Bibliography}

Agamben, Giorgio. "On Potentiality," in Potentialities: Collected Essays in Philosophy, ed. and trans. Daniel Heller-Roazen (Stanford: Stanford University Press, 1999)

Araoz, Gustavo F. "World-Heritage Historic Urban Landscapes: Defining and Protecting Authenticity". in APT Bulletin, Vol 39, no 2/3. (2008), pp 33-37

Architecture for Humanity. Design like You Give a Damn: Architectural Responses to Humanitarian Crises. New York, NY: Metropolis, 2006. Print.

Baydar, Gulsum. "The Cultural Burden of Architecture." Journal of Architectural Education (2004): $19-27$.

Beaudrillard, Jean. Ed. Proto, Francesco. Mass Identity Architecture. Chichester, Wiley-Academy, 2006

Beiser, Morton; DeVoretz, Don, and Pivnenko, Sergiy. The Economic Experience of Refugees in Canada. Burnaby, B.C.: Vancouver Centre for Excellence, 2004. Web (Saint-Lazare, Quebec : Gibson Library Connections, 2008).

Bevan, Robert. The Destruction of Memory: Architecture at War. London: Reaktion, 2007. Print.

Brydon, Diana. "Why Community is Important". Renegotiating Community: Interdisciplinary Perspectives, Global Contexts. Ed. Brydon, Diana, and William D. Coleman. Vancouver: UBC, 2008. Print.

Brydon, Diana, and William D. Coleman. Renegotiating Community: Interdisciplinary Perspectives, Global Contexts. Vancouver: UBC, 2008. Print.

Caglar, Ayse S. Hyphenated Identities and the Limits of "culture" 1997. Print.

Cameron, Christina. "From Warsaw to Mostar: The World Heritage Committee and Authenticity." APT Bulletin 39.2/3 (2008): 19-24.

CBC News Online. Forum Addresses Depression in the Somali Community. March 5, 2010

Crossley, B. Tusha. "Fundamentals of Government Sponsored Refugee Settlement." Immigrants and Refugees in Canada: A National Perspective on Ethnicity, Multiculturalism and Cross-Cultural Adjustment. Ed. Sharma, Satya P. Ervin, Alexander M. and Meintel, Deirdre. Saskatoon: University of Saskatchewan. 159-166 
Curtin, Philip D. Cross-cultural Trade in World History. Cambridge [u.a.: Cambridge UP, 2002. PDF.

Eliot, T.S., After the Strange Gods. London, Faber and Faber, 1934. Print.

Ervin, Alexander M. and Welin, Louise. "Refugee Clients and Social Service Agencies: Some Aspects of Cross-Cultural Misunderstanding." Immigrants and Refugees in Canada: A National Perspective on Ethnicity, Multiculturalism and Cross-Cultural Adjustment. Ed. Sharma, Satya P. Ervin, Alexander M. and Meintel, Deirdre. Saskatoon: University of Saskatchewan. 178-185

Ford, Henry. Interview in Chicago Tribune, May 25th, 1916.

Fuchs, Linda. "Factors Affecting Levels of Happiness Among Southeast Asian Refugee Women in Saskatoon". Immigrants and Refugees in Canada: A National Perspective on Ethnicity, Multiculturalism and Cross-Cultural Adjustment. Ed. Sharma, Satya P. Ervin, Alexander M. and Meintel, Deirdre. Saskatoon: University of Saskatchewan. 147-159

Geertz, Clifford. "Art as a Cultural System." MLN 91.6 (1976): 1473-499. Web.

Geertz, Clifford. The Interpretation of Cultures. New York, Perseus, 2000.

Gupta, Akhil, and James Ferguson. Culture, Power, Place: Explorations in Critical Anthropology. Durham, NC: Duke UP, 1997. Print.

Gwynne-Vaughan, Stephen. A General Model of Refugee Migration: Home, Displacement, and Host Related Factors in the Resettlement of Somali Refugees in Ottawa. Thesis. Carleton University, 1999. Ottawa: Carleton University, 1999. Print.

Hughes, Jonathan, and Simon Sadler. Non-plan: Essays on Freedom Participation and Change in Modern Architecture and Urbanism. Oxford: Architectural, 2000. Print.

Hobsbawm, E. J., and T. O. Ranger. The Invention of Tradition. Cambridge [Cambridgeshire: Cambridge UP, 1983. Print.

International Council on Monuments and Sites. Venice Charter: International Charter for Conservation and Restoration of Monuments and Sites. 1964

International Council on Monuments and Sites. Declaration of San Antonio : InterAmerican Symposium on Authenticity in the Conservation and Management of the Cultural Heritage, 1992. Section B Article 5.

Jerome, Pamela. "An Introduction to Authenticity in Preservation." APT Bulletin 39.2/3 (2008): 3-7.

Kirshenblatt-Gimblett, Barbara. "Theorizing Heritage." Ethnomusicology 39.3 (1995): 367-80. 
Kofman, Eleonore and Lebas, Elizabeth. "Recovery and Reappropriation in Lefebvre and Constant". Nonplan: Essays on Freedom Participation and Change in Modern Architecture and Urbanism. Ed. Hughes, Jonathan, and Simon Sadler. Oxford: Architectural, 2000. Print.

Landau, Ryston. A Philosophy of Enabling", The Square Book. Ed. Price, Cedric. Chichester: WileyAcademy, 2003. Print

Lawrence, Roderick J. "House Form and Culture: What have we Learnt in Thirty Years?" Culture Meaning - Architecture: Critical Reflections on the Work of Amos Rapapor. Ed. Moore, Keith Diaz. Burlington: Ashgate, 2000. Print.

Magro, Karen. Building Bridges to Social Inclusion: Researching the Experiences and Challenges of the Lost Boys and Girls of Sudan Community in Winnipeg. Edmonton, Alta. : Prairie Metropolis Centre, 2009. Web. (Saint-Lazare, Quebec : Gibson Library Connections, 2009)

McNeill, William Hardy. The Pursuit of Power: Technology, Armed Force, and Society since A.D. 1000. Chicago: University of Chicago, 1982. Print.

Mitchell, Nora J. "Considering the Authenticity of Cultural Landscapes." APT Bulletin 39.2/3 (2008): 2531.

Moore, Keith Diaz (ed). Culture - Meaning - Architecture: Critical Reflections on the Work of Amos Rapaport. Burlington: Ashgate, 2000. Print.

Morris, Loveday. "Bomb Attacks in Iraq and Pakistan Target Shiite Pilgrims. The National (Online): Feb 06, 2010.

Niedermuller, Peter. "Ethnicity, Nationality, and the Myth of Cultural Heritage: A European View." Journal of Folklore Research 36.2/3 (1999).

O'Gorman, Kevin D. and Prentice, Richard C. (2008) Iranian hospitality: from caravanserai to bazaar to reporting symbolic experience. In: EuroCHRIE 2008 Congress, 11-14 October 2008, Dubai, United Arab Emirates. 3

Oliver, Paul. Built to Meet Needs: Cultural Issues in Vernacular Architecture. New York, Elsevier, 2006

Pieterse, Jan N. Globalization and Culture: Global Melange. Toronto, Rowman and Littlefield, 2009

Price, Cedric. The Square Book. Chichester: Wiley-Academy, 2003. Print

Rapaport, Amos M. "Culture and Built Form - A Reconsideration". Culture - MeaningArchitecture: Critical Reflections on the Work of Amos Rapapor. Ed. Moore, Keith Diaz. Burlington: Ashgate, 2000. Print. 
Redmond, David, and Associates; for Canadian Mortgage and Housing Corporation - Research Division. Refugee Housing Information Needs: Research Conducted in the Region of Niagara. Ottawa, Ontario: Canada Mortgage and Housing Corporation, 2004 (Saint-Lazare, Quebec : Gibson Library Connections, 2008).

Reuters Africa. Timeline: Deadliest Attacks in Iraq Last Year. Reuters News Service [Online]: March 30, 2011.

Rogers, Marion G. "Church of the Week". Ottawa Journal [Ottawa] Friday, June 30, 1978. Print.

Rogers, Marion G. "Ukrainian Orthodox Cathedral". Ottawa Journal [Ottawa] 1979. Print.

Rossler, Mechtild. "Applying Authenticity to Cultural Landscapes." APT Bulletin 39.2/3 (2008): 47-52.

Sabourin, Dan. Personal Interview. March 25, 2011

Sims, Eleanor. 1978. "Trade and Travel: Markets and Caravansara". Architecture of the Islamic World Its History and Social Meaning. Ed. Michell, George. 1978. London: Thames and Hudson Ltd, 101

Speer, Albert. "Foreword." Foreword. Albert Speer: Architecture 1932-1942. Bruxelles: Archives D'Architecture Moderne, 1985. 213-14. Print.

Statistics Canada. Facts and Figures: Statistical Overview of the Temporary Resident ad Refugee Claimant Population. 2002. Web.

Storper, Michael." Lived Effects of the Contemporary Economy: Globalization, Inequality, and Consumer Society." Public Culture 12.2 (Spring 2000): 375-409.

Stovel, Herb. "Foreword: Working towards the Nara Document". in Larsen xxxiv, 105-106. Print.

Taylor, Donald D. "Vietnamese Refugee Adaptation in Three Contexts: A Life History Approach". Immigrants and Refugees in Canada: A National Perspective on Ethnicity, Multiculturalism and Cross-Cultural Adjustment. Ed. Sharma, Satya P. Ervin, Alexander M. and Meintel, Deirdre. Saskatoon: University of Saskatchewan. 139-147.

Turner, Victor Witter. The Ritual Process: Structure and Anti-structure. Chicago: Aldine Pub., 1969. Print.

Van Esterik, John L. "Communication Claims in a Refugee Program: Case Study of an Anthropologist as a Service Provider." Immigrants and Refugees in Canada: A National Perspective on Ethnicity, Multiculturalism and Cross-Cultural Adjustment. Ed. Sharma, Satya P. Ervin, Alexander M. and Meintel, Deirdre. Saskatoon: University of Saskatchewan. 178-185

Vitruvius, On Architecture, Granger, trans., p. 7. 
Vodanovic, Lucia. "Obsolescence and Exchange in Cedric Price's Dispensable Museum." Invisible Culture 1.11 (2007). Web.

<http://www.rochester.edu/in_visible_culture/Issue_11/vodanovic/vodanovic.htmis.

Wald, Alan. "Theorizing Cultural Difference: A Critique of the "Ethnicity School"" Melus 14.2 (1987): 2133. Web.

Weizman, Eyal. Hollow Land. New York: Verso, 2007.

Yavuz, Aysil Tükel. 1997. "The Concepts that Shape Anatolian Seljuq Caravansara." In: Gülru Necipoglu (ed). 1997. Muqarnas XIV: An Annual on the Visual Culture of the Islamic World. Leiden: E.J. Brill, 80-95. 